When 101. 4 if IIIIIII WETENSCHAPPELIJKE RAAD VÓOR HET REGERINGSBELEID | 1) 1 inge if if if 146.
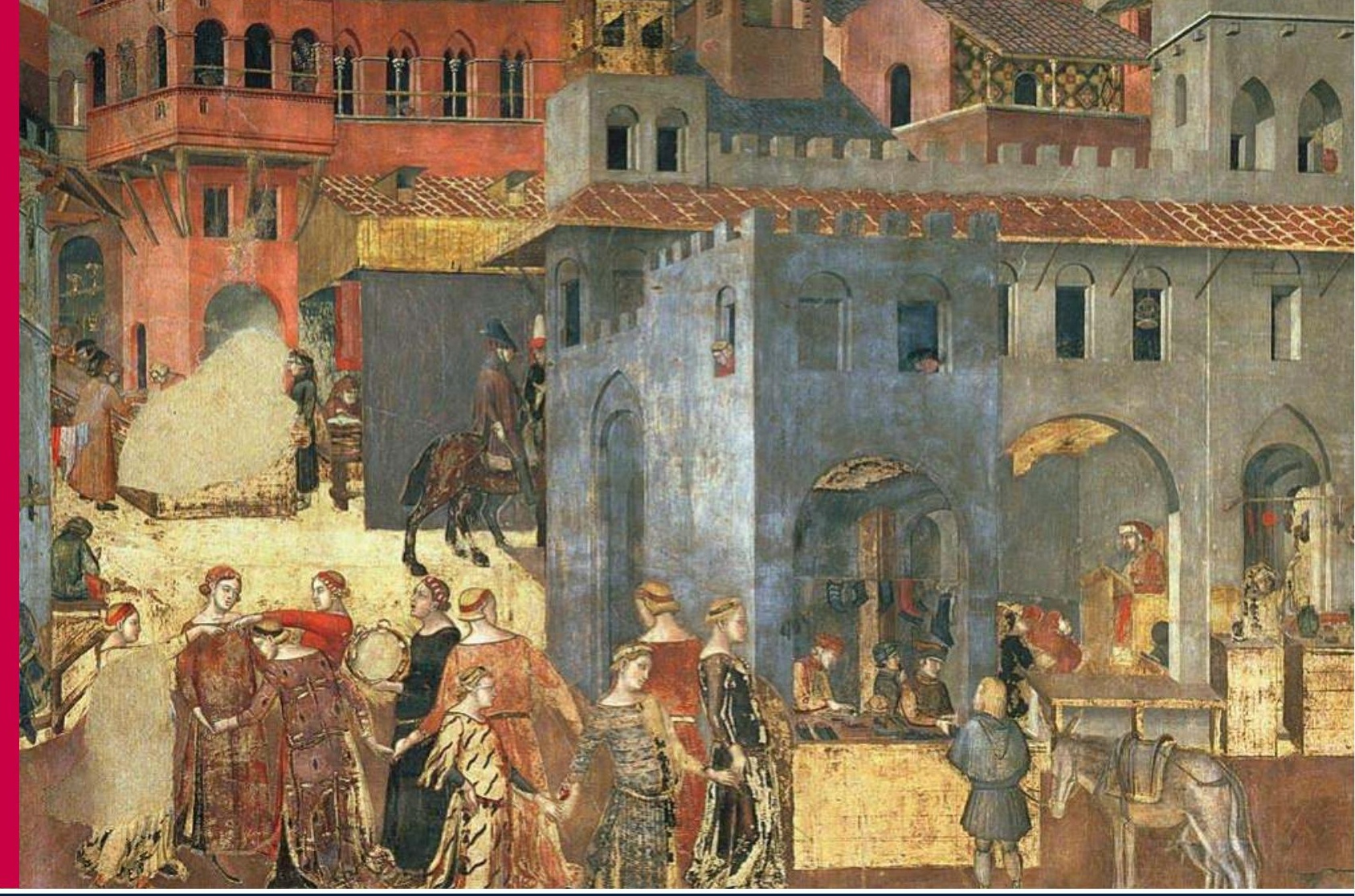

\title{
Lerende overheid
}

EEN PLEIDOOI VOOR PROBLEEMGERICHTE POL I T IEK

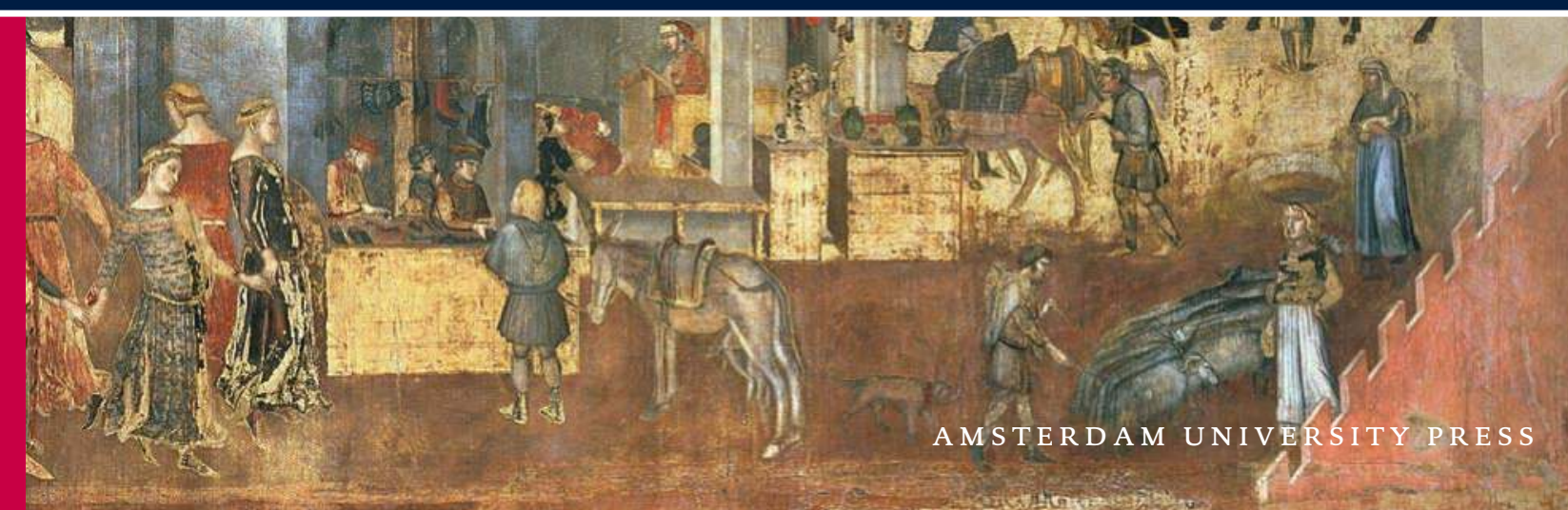


Lerende overheid 
De Wetenschappelijke Raad voor het Regeringsbeleid werd in voorlopige vorm ingesteld in 1972. Bij wet van 30 juni 1976 (Stb. 413) is de positie van de raad definitief geregeld. De huidige zittingsperiode loopt tot 31 december 2007.

Ingevolge de wet heeft de raad tot taak ten behoeve van het regeringsbeleid wetenschappelijke informatie te verschaffen over ontwikkelingen die op langere termijn de samenleving kunnen beïnvloeden. De raad wordt geacht daarbij tijdig te wijzen op tegenstrijdigheden en te verwachten knelpunten en zich te richten op het formuleren van probleemstellingen ten aanzien van de grote beleidsvraagstukken, alsmede op het aangeven van beleidsalternatieven.

Volgens de wet stelt de WRR zijn eigen werkprogramma vast, na overleg met de minister-president die hiertoe de Raad van Ministers hoort.

De samenstelling van de raad is (tot 31 december 2007):

prof. dr. W.B.H.J. van de Donk (voorzitter)

mw. prof. dr. L. Hancher

prof. dr. P.A.H. van Lieshout

prof. dr. P.L. Meurs

prof. dr. J.L.M. Pelkmans

drs. I.J. Schoonenboom

prof. dr. J.J.M. Theeuwes

prof. dr. P. Winsemius

Secretaris: prof. dr. A.C. Hemerijck

Plaatsvervangend secretaris: dr. R.J. Mulder

De WRR is gevestigd:

Lange Vijverberg 4-5

Postbus 20004

2500 EA 's-Gravenhage

Telefoon 070-356 46 oo

Telefax 070-356 4685

E-mailinfo@wrr.nl

Website http://www.wrr.nl 


\section{Lerende overheid}

EEN PLEIDOOI VOOR PROBLEEMGERICHTE POLITIEK 
Omslagafbeelding: Gli effetti del Buon Governo (Effecten van goed bestuur), 1338-40, Lorenzetti, Ambrogio (1285-ca. 1348) / Palazzo Pubblico, Siena, Italië / The Bridgeman Art Library. Fragment van de Gevolgen van goed bestuur in stad en land, 1338-1340, muurschildering van Ambrogio Lorenzetti, Siena. Het complete werk in het Palazzo Pubblico in Siena laat symbolische voorstellingen zien van het goede bewind en het slechte bewind.

Omslagontwerp: Studio Daniëls, Den Haag

Vormgeving binnenwerk: Het Steen Typografie, Maarssen

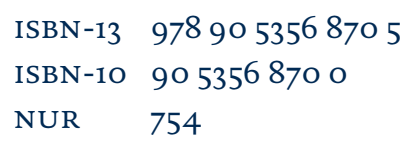

(C) WRR/Amsterdam University Press, Den Haag/Amsterdam 2006

Alle rechten voorbehouden. Niets uit deze uitgave mag worden verveelvoudigd, opgeslagen in een geautomatiseerd gegevensbestand, of openbaar gemaakt, in enige vorm of op enige wijze, hetzij elektronisch, mechanisch, door fotokopieën, opnamen of enige andere manier, zonder voorafgaande schriftelijke toestemming van de uitgever.

Voor zover het maken van kopieën uit deze uitgave is toegestaan op grond van artikel 16B Auteurswet $1912 j^{\circ}$ het Besluit van 20 juni 1974, Stb. 351, zoals gewijzigd bij het Besluit van 23 augustus 1985, Stb. 471 en artikel 17 Auteurswet 1912, dient men de daarvoor wettelijk verschuldigde vergoedingen te voldoen aan de Stichting Reprorecht (Postbus 3051, $2130 \mathrm{~KB}$ Hoofddorp). Voor het overnemen van gedeelte(n) uit deze uitgave in bloemlezingen, readers en andere compilatiewerken (artikel 16 Auteurswet 1912) dient men zich tot de uitgever te wenden. 


\section{WRR}

WETENSCHAPPELIJKE RAAD VOOR HET REGERINGSBELEID

Aan de Minister-president

Voorzitter van de Ministerraad

Mr.dr. J.P. Balkenende

Postbus 20001

2500 EA DEN HAAG

ons kenmerk

2006102/wvdd/ydg

onderwerp

WRR-rappoit nr. 75

\author{
doorkiesnummer \\ 070-3564638 \\ e-mail \\ voorzitter@wrr.nl
}

\author{
telefax \\ 070-3564685 \\ Datum \\ 13 september 2006
}

Het doet mij genoegen u hierbij aan te mogen bieden het rapport 'Lerende Overheid. Een pleidooi voor probleemgerichte politiek'. Het rapport vloeit mede voort uit de vele discussies die de raad heeft gevoerd naar aanleiding van het eerder in deze raadsperiode verschenen rapport 'Bewijzen van goede dienstverlening'. Die discussies waren voor de raad aanleiding verder onderzoek te doen naar de manier waarop en het klimaat waarin politiek en overheid dezer dagen worden geconfronteerd met wat de raad omschrijft als 'ongetemde' maatschappelijke problemen; denk aan de veranderingen in het klimaat of de toekomst van de verzorgingsstaat. De normatieve en cognitieve complexiteit van dit type problemen stelt bijzondere eisen aan de wijze waarop ze worden aangepakt.

Het rapport en het daaraan ten grondslag liggende onderzoek beschrijft en analyseert maatschappelijke en politieke probleemoplossing als een 'gemengde praktijk', waarin zowel politici, ambtenaren als maatschappelijke organisaties en burgers een belangrijke inhoudelijke bijdrage hebben te leveren. Een lerende overheid is een overheid die van de inhoudelijke inbreng van zijn ambtenaren en maatschappelijke actoren adequaat gebruik weet te maken. Een overheid die zich realiseert dat spreiding van verantwoordelijkheden en het delen van kennis en inzichten wezenlijke voorwaarden zijn voor effectieve en legitieme vormen van beleidsvoering. Meer dan als een doeltreffende besluitvormingsmachine, moet de politiekbestuurlijke praktijk worden gezien als een rijk ecosysteem, waarvan de vitaliteit en variëteit zou moeten worden gekoesterd als een belangrijke bron van slimme oplossingen voor ingewikkelde problemen. Het rapport laat zien hoe het leervermogen van de overheid soms wordt bedreigd, en wijst enkele wegen hoe het zou kunnen worden versterkt.

Daarmee beoogt het rapport een bijdrage te leveren aan de bredere discussie die in het komende jaar op initiatief van de ministerraad en anderen zal worden gevoerd over de inrichting en werking van overheid en politiek, en wordt er bijzondere aandacht gegeven aan de positie van het ambtelijk apparaat en van de volksvertegenwoordiging.

Volgens de procedure van de Instellingswet ziet de raad graag de reactie van de ministerraad tegemoet.

De voorzitter,

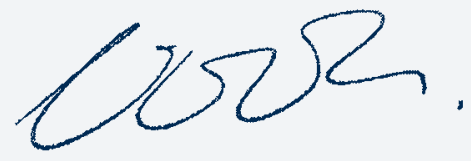

Prof.dr. W.B.H.J. van de Donk

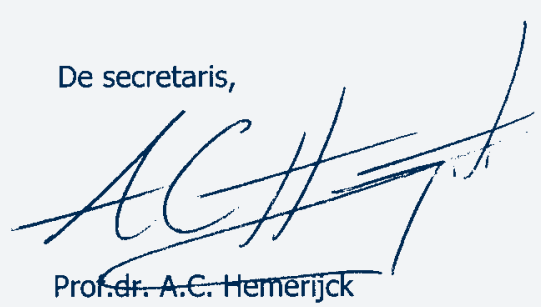




\title{
INHOUDSOPGAVE
}

\author{
Samenvatting
}

Ten geleide

$1 \quad$ Inleiding en probleemstelling 19

$\begin{array}{ll}1.1 & \text { Een gevoel van onbehagen }\end{array}$

1.2 Probleemstelling 22

1.3 Opbouw van het rapport 26

2 Leren van ongetemde problemen 29

2.1 Inleiding 29

$2.2 \quad$ Ongetemde problemen 32

$2.3 \quad$ 'Lerende overheid' $\quad 36$

2.4 De huidige politieke context; dominante reacties 38

$2.5 \quad$ Politiek-ambtelijke verhoudingen $\quad 42$

$\begin{array}{lll}2.6 & \text { Conclusie } & 45\end{array}$

$3 \quad$ Horizontale en verticale traditie van politiek $\quad 47$

$\begin{array}{lll}3.1 & \text { Inleiding } & 47\end{array}$

3.2 Klassieke verklaringen voor het falen van de politiek $\quad 47$

3.3 Twee politieke tradities 53

3.3.1 De verticale traditie $\quad 54$

3.3.2 De horizontale traditie $\quad 55$

3.3.3 De verticale versus de horizontale traditie 57

$\begin{array}{lll}3.4 & \text { Oordelen over politiek } & 59\end{array}$

3.5 Verbetering van het functioneren van overheid en politiek 62

$\begin{array}{lll}3.6 & \text { Conclusie } & 66\end{array}$

4 Politiek in Nederland : gemengd bedrijf 69

4.1 Verticale en horizontale aspecten van de Nederlandse politiek 69

$\begin{array}{lll}\text { 4.1.1 De euthanasieproblematiek } & 71\end{array}$

$\begin{array}{lll}\text { 4.1.2 Stakingsrecht } & 73\end{array}$

4.1.3 Het Akkoord van Wassenaar $\quad 74$

4.1.4 Voorbereiding op de invoering van de Vreemdelingenwet 2000 $\quad 76$

$\begin{array}{ll}\text { 4.1.5 Intelligente combinaties } & 78\end{array}$

4.2 Veranderende rollen van ambtenaren 81

$\begin{array}{lll}\text { 4.2.1 Procesmanager en professionele ambtenaar } & 81\end{array}$

4.2.2 Veranderende verhoudingen 83

$\begin{array}{lll}4.3 & \text { Een rijk bestuurlijk ecosysteem } & 85\end{array}$

$\begin{array}{ll}4 \cdot 3 \cdot 1 \quad \text { Onoverzichtelijk? } & 86\end{array}$

$\begin{array}{lll}4.3 .2 & \text { Collectieve leerprocessen } & 87\end{array}$

4.3.3 Voordelen van gemengde praktijken 92 
4.4 Spanningen binnen het gemengd bedrijf 94

4.4.1 Deskundigheid versus democratische legitimiteit 96

$\begin{array}{ll}\text { 4.4.2 Rechtsstaat en politiek maatwerk } & 98\end{array}$

$\begin{array}{lll}4.5 & \text { Conclusie } & 101\end{array}$

$5 \quad$ Een probleemgerichte benadering 103

$\begin{array}{lll}5.1 & \text { Inleiding } & 103\end{array}$

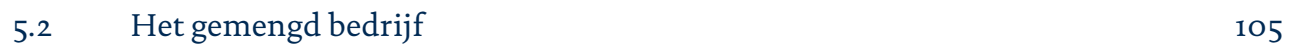

$\begin{array}{lll}\text { 5.2.1 Twee tradities } & 105\end{array}$

$\begin{array}{ll}\text { 5.2.2 Een goed klimaat om te leren } & 107\end{array}$

5.2.3 Miskenning gemengde praktijk: verticale traditie de meetlat 109

5.3 Leervermogen onder druk 111

$\begin{array}{lll}5.4 & \text { Een aanvullend perspectief: lerende overheid } & 117\end{array}$

$\begin{array}{ll}\text { Literatuur } & 127\end{array}$ 


\section{SAMENVATTING}

\section{Achtergrond en probleemstelling}

Er bestaat onder zowel burgers als politici veel onbehagen over het politieke bestel. Zo worden er vragen gesteld bij het functioneren van politici: zijn zij voldoende aansprekend, vertrouwenwekkend en geloofwaardig? Pakken zij wel de goede zaken aan? Is er wel voldoende politiek leiderschap? Ook het probleemoplossend vermogen van de overheid roept de nodige scepsis op. Er is kritiek op de gebrekkige aansluiting tussen beleid en uitvoering en op de wijze waarop problemen worden aangepakt.

Dit onbehagen wordt geuit tegen de achtergrond van een specifiek beeld van wat van de politiek zou mogen worden verwacht. In dat beeld worden politici geacht gezaghebbende besluiten te nemen op basis van kiezersvoorkeuren, waarna hun besluiten door ambtenaren loyaal dienen te worden geïmplementeerd en uitgevoerd. Verantwoording zou daarna in omgekeerde richting dienen plaats te vinden. Aan dat alles zou het nu schorten.

Om aan het onbehagen een einde te maken worden oplossingen voorgesteld die de verwachtingen die in het genoemde beeld besloten liggen alsnog zouden moeten inlossen. Het primaat van de politiek moet worden hersteld en er moet meer leiderschap worden getoond. Het onderscheid tussen de verantwoordelijkheden van politieke gezagsdragers en het ambtenarenapparaat moet helderder worden. En binnen de overheid moet het beheer van processen en procedures voorop komen te staan en moet efficiency meer nadruk krijgen. De kiezer moet krijgen waarom hij vraagt.

Deze visie op het functioneren van het politieke bestel is volgens de raad niet altijd productief. De roep om daadkracht staat het besef in de weg dat veel problemen waarvoor de overheid komt te staan complex zijn en dat er ruimte en tijd voor analyse, afweging en oordeelsvorming nodig zijn. Wanneer zich problemen aandienen is vaak nog niet duidelijk wat precies het probleem is, hoe zij behandeld moeten worden en waar en op welke manier dat het beste kan plaatsvinden. De raad spreekt in dit rapport in zulke gevallen van ongetemde problemen. $\mathrm{Zij}$ worden voor alles gekenmerkt door cognitieve en normatieve onzekerheid. Toen zich bijvoorbeeld de eerste tekenen aandienden van de aids-epidemie, de BSE-crisis en de snel oplopende werkloosheid in de jaren tachtig, dienden zich zulke 'ongetemde' problemen aan. Ook nu wordt de overheid ermee geconfronteerd. Te denken valt aan de gevolgen van klimaatverandering, de kans op nieuwe wereldwijde epidemieën, aan medisch-ethische vraagstukken, de veiligheidsproblematiek en de toekomstige inrichting van de verzorgingsstaat.

Wanneer zich 'ongetemde' problemen aandienen is kennis over de aard van het probleem en de richting van de oplossing niet meteen voorhanden en bestaat doorgaans onenigheid over wat de beste koers zou moeten zijn. Het vraagt om 
een benadering waarin het leren van ervaringen centraal staat en waarin het belang van wikken en wegen om tot afgewogen besluitvorming te komen wordt gewaardeerd. Het 'domesticeren' van 'ongetemde' problemen vereist de tijd en de inzet van velen, vaak ook van actoren buiten de overheid zelf: deskundigen, burgers en maatschappelijke organisaties.

\section{Verticale en horizontale politiek}

De visie op het politieke bestel die momenteel in het denken over politiek dominant is en die tot uitdrukking komt in de manier waarop het genoemde onbehagen wordt verwoord, situeert de raad in wat in dit rapport de 'verticale traditie' van politiek denken wordt genoemd. In die traditie staat het nemen van legitieme beslissingen centraal en zijn politici degenen die de knopen doorhakken en wetten uitvaardigen, die macht hebben en daarom moeten worden gecontroleerd.

Die controle vindt plaats door formeel toezicht en verantwoording te regelen. De raad wijst er op dat naast deze traditie van oudsher een tweede stijl van denken over politiek bestaat, die in dit rapport de 'horizontale traditie' wordt genoemd. In de horizontale traditie staat het in redelijkheid besturen centraal en is de politicus de bestuurder die nieuwe vormen van collectief handelen ontwikkelt waarin uiteenlopende inzichten worden verzoend. In deze traditie richt politiek zich op wikken en wegen en op het formuleren van oplossingen die aanspraak kunnen maken op redelijkheid.

In het feitelijke politieke handelen spelen elementen van beide tradities een rol. Politiek in Nederland is een 'gemengd' bedrijf. Het politieke bestel mag daardoor onoverzichtelijk lijken, maar, zo betoogt de raad, het biedt door het gemengde karakter een omgeving waarin het mogelijk is te leren hoe problemen geformuleerd en opgelost kunnen worden. Het biedt mogelijkheden voor een bestuur dat zich richt op inhoudelijke redelijkheid en op democratische legitimiteit. Het blijkt een goede omgeving om te leren hoe problemen geformuleerd en opgelost kunnen worden.

Zodra over politiek gesproken wordt vormt de verticale traditie, in weerwil van het feitelijke gemengde karakter van de politiek, de maatstaf. De horizontale traditie verdwijnt uit het zicht. Hierdoor ontstaat een eenzijdig en dus verarmd beeld dat onze waardering van de politiek en haar rol in de samenleving beperkt. Het beïnvloedt ook de oplossingen voor de tekortkomingen van de politiek gezocht kunnen worden. Ongenoegen over de kwaliteit van het beleid en het bestuur wordt dan automatisch vertaald in voorstellen voor het stroomlijnen van de manier waarop delegatie van macht en verantwoording plaatsvindt. Er wordt gepleit voor meer toezicht, voor nieuwe procedures, voor referenda, voor één loket en voor websites die de communicatie tussen burgers, politici en overheid bevorderen.

Naar het oordeel van de raad bieden zulke oplossingen voor de omgang met 'ongetemde' problemen geen soelaas. Normatieve vragen en inhoudelijke afwegingen verdwijnen naar de achtergrond ten gunste van een benadering die de trans- 
parantie van het proces, het correct volgen van de procedures, en het meten en controleren van het resultaat centraal stellen. In zo'n klimaat wint keuze voor stellige uitspraken het van lastige boodschappen, de constructieve dialoog, de bezinning en het onderzoek.

Het eenzijdig versterken van de verticale traditie in plaats van het zoeken naar intelligente combinaties, brengt een vijftal risico's met zich mee.

1 Bestuurscentrisme. Het eigen perspectief van overheid en politiek op problemen komt centraal te staan. De buitenwereld wordt beschouwd als een verlengstuk van de eigen organisatie, de samenleving als te bestuderen object gezien.

2 Dominantie van procesdenken. Politiek en overheid gaan zich steeds meer richten op het perfectioneren van procedures en regels en op het beheren en beheersen van beslissingsprocessen. De bestuurlijke procesoriëntatie wint het van de maatschappelijke probleemoriëntatie.

3 Dilemma's worden omzeild in plaats van onderkend. De twee politieke tradities laten zich niet altijd makkelijk verenigen. Er kunnen op verschillende momenten en manieren spanningen ontstaan, bijvoorbeeld tussen maatwerk en gelijkheid of effectiviteit en legitimiteit. Pas als gemengde praktijken worden beproefd kunnen deze spanningen worden onderzocht en van een passend antwoord voorzien.

4 Bureaucratisering van ervaring. In de verticale traditie is een centrale plaats ingeruimd voor processen van verantwoording. Het risico is dat relevante ervaring vervormd wordt tot informatie die in een bureaucratisch systeem kan worden verwerkt, en daardoor juist zijn relevantie voor het leervermogen verliest.

5 Eenzijdige politisering van informatie. Ten slotte is er het risico dat informatie eenzijdig wordt ingezet om de controletaak van de politiek uit te oefenen. Voor zover er sprake is van leerprocessen, zijn deze hoofdzakelijk gericht op het doorvoeren van aanpassingen binnen bestaande kaders. Leren krijgt de vorm van controleren.

\section{Probleemgerichte benadering}

De raad kiest voor een benadering waarin de overheid leert hoe met 'ongetemde' problemen om te gaan en waarin de inhoudelijke en normatieve oriëntatie op problemen centraal komt te staan. Het zoeken naar passende probleemdefinities, het betrekken van verschillende publieken en het verzamelen van verschillende bronnen van kennis en ervaring dient daarbij meer aandacht te krijgen dan de benadering waarbij posities het vertrekpunt zijn. Juist waar sprake is van 'ongetemde' problemen is het van belang de wendbaarheid en inhoudelijke expertise van de overheid te borgen en te versterken. Hiermee is uiteraard niet gezegd dat beslissen en doorzetten altijd verkeerd zouden zijn. Vooral bij 'ongetemde' problemen is een aanvullend repertoire echter gewenst. 
Dat repertoire hoeft in de meeste gevallen niet opnieuw te worden uitgevonden. Voorbeelden van een meer inhoudelijke en probleemgerichte manier van politiek bedrijven zijn reeds volop beschikbaar. We dienen echter meer oog en waardering te krijgen voor het idee dat politiek ook een zaak is van collectieve leerprocessen.

\section{Agenda voor overheid en politiek}

Een 'lerende' overheid onderkent dat zij voor 'ongetemde' problemen afhankelijk is van de inbreng van tal van maatschappelijke actoren. Daarnaast investeert zij in rust en bedachtzaamheid in de politiek.

\section{Inhoudelijke ambtenaren}

Hogere ambtenaren kunnen meer worden aangesproken als inhoudelijk adviseur van de politiek verantwoordelijken. Het is van belang hun rol als coproducent van beleid te erkennen en te benutten. De raad pleit daarom voor ambtelijke professionaliteit waarbij inhoudelijke kennis van zaken voorop staat. Het kunnen activeren van arena's waar kennis bijeen wordt gebracht is een belangrijke competentie van ambtenaren. Dat vereist naast de proces-managementkwaliteiten die nu voorop staan inhoudelijke deskundigheid. De nu wel zeer dominante rol van de ambtenaar als procesarchitect kan meer naar de achtergrond schuiven. Bij een meer inhoudelijke taak past ook dat ambtenaren in specifieke situaties gericht zelf Kamerleden informeren.

\section{Het parlement: inspirator naast controleur}

In hun vertegenwoordigende rol hebben parlementsleden vooral de taak om de verscheidenheid aan meningen en opinies bijeen te brengen en te wegen. Dat is iets anders dan het louter weerspiegelen van die meningen. Tot de kern van de opdracht van het parlement behoort het interpreteren, beoordelen en zonodig bekritiseren van wat in de samenleving naar voren wordt gebracht. In een democratie is voor het parlement bovendien een vitale rol weggelegd om ook het nog niet of onvoldoende gerepresenteerde voor het voetlicht te brengen, om te onderzoeken welke zaken zijn blijven liggen en ook om daar waar nodig de stem van assertieve burgers en goed georganiseerde belangengroepen te dempen. Dit betekent niet dat de controlerende taak onbelangrijk is, wel dat het parlement meer werk kan maken van haar inspirerende rol als wetgever en vertegenwoordiger.

Een bijzondere taak van Kamerleden bestaat in het articuleren van publieke problemen waarvoor nog geen oplossing voorhanden is, of waar bestaande oplossingen omstreden zijn geraakt of onbedoelde bijwerkingen hebben. Voor een meer gedegen kennisverzameling is nodig dat Kamerleden uit de eerste hand de benodigde kennis en ervaring verzamelen. Naar het oordeel van de raad vormt de vaardigheid problemen te onderzoeken dan ook een belangrijke kwaliteit van Kamerleden. Het parlement heeft bovendien de verantwoordelijkheid horizontale politiek, die vaak ook actoren buiten de overheid omvat, te stimuleren en te legitimeren. Het parlement zou moeten kunnen beoordelen of alle relevante partijen voldoende gehoord zijn. Daarbij hoort ook de mogelijkheid van een pas 
op de plaats in het wetgevingsproces om terug te keren naar de inhoud en te oordelen over de effecten van amendementen op de consistentie en uitvoerbaarheid van wetten. Andersom kunnen politici ook bevorderen dat onderwerpen daadwerkelijk publiek worden. Mits daadwerkelijk aangewend als instrument voor onderzoek, vormen de parlementaire enquête en het parlementair onderzoek daarvoor uitstekende middelen.

\section{Regeren met een inhoudelijk programma}

Een overheid die werkt vanuit een inhoudelijke oriëntatie is niet gebaat bij een aan het begin van een Kabinetsperiode gesloten contract waarin van tevoren volledig wordt vastgelegd wat de inspanningen en resultaten zullen zijn. Een regeerprogramma waarin op hoofdlijnen de inhoudelijke prioriteiten worden bepaald biedt meer mogelijkheden om gaande de rit gebruik te maken van op gedane ervaringen en zo te leren en tot bijstellingen te komen. Deze werkwijze heeft het bijkomende voordeel dat bewindspersonen zullen investeren in goede probleemdefinities en in verkenning van elkaars meningen en overtuigingen, zonder dat onderhandeld hoeft te worden in de slagschaduw van een van tevoren afgesproken resultaat.

\section{Open verhoudingen}

Wat de politiek-ambtelijke verhoudingen betreft pleit de raad voor wederzijdse investering, zodat kennis en ervaring gedeeld kunnen worden met inachtneming van de onderscheiden rollen en posities. Juist bij nog 'ongetemde' problemen is een open relatie tussen Kamer en departementen gewenst. De meerwaarde van politiek en overheid ligt in de onderlinge verbinding tussen de normatieve en de inhoudelijke inbreng van politici en ambtenaren.

Het vertrouwen van burgers in overheid en politiek is gebaat bij ambtenaren, ministers en politici die gezamenlijk investeren in de oplossing van maatschappelijke vraagstukken. De Nederlandse samenleving beschikt over een rijke traditie waarin op basis van wederzijds vertrouwen geleerd wordt om te gaan met de 'ongetemde' problemen waarmee overheid en politiek steeds weer worden geconfronteerd. Juist omdat deze vorm van bestuur niet generiek inzetbaar is, maar steeds opnieuw bepaald en gespecificeerd dient te worden, is zorg voor de inhoud, de wijze van afwegen en beoordelen onontbeerlijk. 




\section{TEN GELEIDE}

Dit rapport is voorbereid door een interne projectgroep van de WRR. Voorzitter was prof.dr. P.L. Meurs, lid van de raad. Prof.dr. G.H. de Vries heeft als gast van de raad deel uitgemaakt van de projectgroep en een essentiële bijdrage geleverd aan de totstandkoming van dit rapport. Verder maakten de volgende stafleden deel uit van de projectgroep: drs. H. Dijstelbloem, prof. dr.

A.C. Hemerijck en drs. E.K. Schrijvers (project-coördinator). Mr. S. Scheijven en mw. W. Zwijnenberg hebben gedurende enkele maanden geparticipeerd in het project en achtergrondmateriaal verzameld.

Dit rapport is ontstaan als een vervolg op het WRR rapport Bewijzen van goede dienstverlening (2004) en de conferenties die naar aanleiding van het verschijnen van het rapport zijn georganiseerd.

Bij het vervaardigen van dit rapport is gebruik gemaakt van een serie essays van verschillende auteurs die op verzoek van de raad en ten behoeve van het rapport zijn vervaardigd. Zij zijn gepubliceerd in een bundel die tegelijk met dit rapport verschijnt: P.L. Meurs, E.K. Schrijvers en G.H. de Vries (red.) (2006) Leren van de praktijk. Gebruik van lokale kennis en ervaring voor beleid, WRR Verkenning 12, Amsterdam: Amsterdam University Press. In deze verkenning zijn essays opgenomen van Marc Hertogh, Klaartje Peters, Gerard de Vries, Bas van Stokkom en Jan Terpstra, Imrat Verhoeven, Paul Dekker, Marjolijn Drenth von Februar, Mirko Noordegraaf en Herman van Gunsteren. 


\subsection{EEN GEVOEL VAN ONBEHAGEN}

In de meeste rapporten die de WRR uitbrengt staat een specifiek politiek onderwerp centraal. In dit rapport is het onderwerp echter de politiek zelf. Daarvoor bestaan goede redenen. Om te beginnen is het vertrouwen van burgers in de politieke instituties zoals de Tweede Kamer, de regering en de politieke partijen de laatste jaren afgenomen, en dat sterker dan in andere Europese landen (SCP 2006). Over de feitelijke bijdrage van de politiek aan het dagelijks leven bestaat bij burgers cynisme (Dekker 2005). De stijl en omgangsvormen in de politiek lijken ergernis te wekken. Opvallend is een forse stijging van de roep om leiderschap (SCP 2006). Maar ook sceptische geluiden van politici zelf zijn aan de orde van de dag. Parlementsleden oordelen steeds vaker publiekelijk in harde, negatieve termen over hun eigen metier of spreken hun waardering uit voor de niet zelden populistisch getinte kritiek van buitenstaanders op het politieke bedrijf. Door ministers wordt geklaagd over de - al dan niet "vieze en vunzige" - "spelletjes" van collega's. "Haags gedoe” en "de Haagse kaasstolp" kunnen inmiddels in de Van Dale worden opgenomen als Standaardnederlandse uitdrukkingen. Klachten over bestuurlijke onoverzichtelijkheid en gebrek aan coördinatie klinken alom in ambtelijke kring, en worden bevestigd door opeenvolgende regeringen die zich negatief hebben uitgelaten over de overheidsbureaucratie ('t Hart en Wille 2006). Er zou te weinig doorzettingsmacht zijn om problemen op te lossen en de combinatie van media-aandacht en Kamervragen zou ministers afhouden van het formuleren van doordacht beleid.

Het brede gevoel van onbehagen richt zich op het politieke bestel als geheel, eerder dan op specifieke beleidsonderdelen. Enerzijds worden vragen gesteld bij het politieke bedrijf. Doen politici wel de goede dingen? Zijn zij voldoende aansprekend, vertrouwenwekkend en geloofwaardig? Is er wel voldoende politiek leiderschap? Het functioneren van de instituties zelf lijkt daarbij minder in het geding dan het gedrag van degenen die in die instituties werkzaam zijn (SCP 2006). Anderzijds roept behalve de legitimiteit van de politiek ook het probleemoplossende vermogen van de overheid vragen op. Hoe kan het dat de overheid er jaar op jaar niet in slaagt beleid en uitvoering beter op elkaar te laten aansluiten? Zijn politici en ambtenaren wel in staat om goede oplossingen voor problemen te vinden? Betrekken ze daar wel de juiste mensen bij, hebben ze voldoende zicht op wat zich in de praktijk afspeelt? En is de rol van de politiek voldoende constructief en inspirerend? Niet alleen dat de goede zaken worden aangepakt, maar ook dat de zaken goed worden aangepakt, spreekt niet meer vanzelf.

De kritiek op het politieke bestel betreft dus zowel de legitimiteit van het optreden van de politiek als de effectiviteit van het overheidshandelen. De manier waarop het ongenoegen geformuleerd wordt suggereert echter dat de oplossing nabij is. De problemen moeten eenvoudigweg 'direct worden aangepakt' en 
'slagvaardig' worden opgelost. De verantwoordelijken moeten hun verantwoordelijkheid nemen, als bevoegd gezag, uitvoerder of toezichthouder. Waar het beleid faalt moeten de schuldigen worden aangewezen en zo mogelijk ook worden bestraft, waarna een nieuwe generatie politici of bestuurders het toneel kan betreden om orde op zaken te stellen. Tegelijkertijd moeten de processen ook efficiënter georganiseerd worden - de overheid is te traag, te bureaucratisch en te weinig gericht op de wensen van de burger.

In het zo spreken over het politieke bestel wordt een specifiek beeld van overheid en politiek als uitgangspunt genomen. Daarin worden politici verondersteld op basis van kiezersvoorkeuren gezaghebbende besluiten te nemen, waarna ambtenaren hun besluiten uitvoeren, eventueel met hulp van maatschappelijke actoren. Als er zich problemen aandienen is de diagnose gauw gesteld en ligt de therapie voor de hand. Het primaat van de politiek moet hersteld worden, er moet leiderschap getoond worden, de verantwoordelijkheden moeten duidelijk worden, de kiezer moet krijgen waarom hij vraagt. Wat de overheid betreft, wordt een scherpere scheiding bepleit tussen politiek en ambtenarenapparaat. Er moet meer efficiency komen, processen moeten beter beheerd worden en als verwacht kan worden dat markt de klus beter kan klaren, moeten taken daarnaartoe worden overgeheveld. Om kort te gaan: politici moeten hun plannen luider en duidelijker verwoorden en harder en scherper ingrijpen. Omdat burgers in een democratie de primaire opdrachtgevers zijn, moeten zij meer formele mogelijkheden krijgen om hun voorkeuren en meningen te uiten, naast de vrijwel dagelijkse opiniepeilingen en enquêtes die over de stemming van het electoraat informeren. Zo krijgen politici het mandaat en het vertrouwen dat ze nodig hebben om daadkrachtig op te treden terug en kunnen zij de vele hardnekkige maatschappelijke vraagstukken waarmee we worden geconfronteerd, eindelijk oplossen.

Het genoemde beeld van overheid en politiek bepaalt zowel de manier waarop de problemen worden gezien als het soort voorstellen dat het onbehagen moet wegnemen. Deze wijze van probleemstellen is volgens de raad niet in alle gevallen productief. Tussen het definiëren van wat er in het geding is en het vinden van bijpassende oplossingen is soms te weinig ruimte voor analyse. Politiek gaat over inhoudelijke en normatieve kwesties. Wanneer oplossingen voornamelijk in de vorm worden gezocht, bestaat het risico dat maatschappelijke vraagstukken onvoldoende inhoudelijk onderzocht en beoordeeld worden. Bij het uiten van twijfel over het politieke bedrijf en het probleemoplossend vermogen van de overheid wordt als teken van de malaise vaak gewezen op bepaalde kwesties: fileproblemen, wachtlijsten in de zorg, integratieproblematiek, onderwijsuitval, geldverslindende infrastructurele projecten en uiteraard regelzucht. Zij worden in de media keer op keer breed uitgemeten. Volksvertegenwoordigers voelen bewindslieden er uitgebreid over aan de tand. Daarbij is echter vaak niet duidelijk of het om incidenten gaat of om structureel onopgeloste vraagstukken. Is er sprake van slechts enkele slecht presterende verpleeghuizen die hun bewoners minder verzorgen, of van het structureel bereiken van de grens van nog toelaatbare bezuinigingen? 
Ondanks de vele hervormingen, de inzet van nieuwe instrumenten, en soms vele miljoenen overheidsfinanciering blijven ze bestaan en lijkt de overheid te falen en de politiek niet in staat voldoende initiërend, corrigerend of inspirerend op te treden. Dit is aan niemand onopgemerkt voorbijgegaan. Al lange tijd wordt geprobeerd het functioneren van overheid en politiek te verbeteren. Zo worden voortdurend voorstellen gedaan om de kloof tussen burger en politiek te verkleinen en de democratie nieuw leven in te blazen. In het hoofdlijnenakkoord van 2003 nog werden de direct gekozen burgemeester, een verandering van het kiesstelsel en een onderzoek naar de rol van de minister-president in het vooruitzicht gesteld. Over de rol en positie van het parlement zijn inmiddels vele adviezen uitgebracht. Sleutelen aan het kiesstelsel wordt al decennialang gepropageerd als het medicijn om het zieke staatsbestel er weer bovenop te helpen (Bos en Loots 2004: 24) en het onderwerp grondwetsherziening staat hoog op de politieke agenda. Het onderwerp structuurwijziging bleek in de jaren negentig zelfs zo populair dat het zich leende voor partijpolitieke profilering (Visscher 2000: 24). Opvallend is daarbij overigens dat de zegeningen van het politieke bedrijf niet worden geteld. Het feit dat bijvoorbeeld de milieuproblematiek, voedselveiligheidsproblemen en aids door de overheid na aanvankelijke startproblemen toch tamelijk effectief behandeld werden, lijkt nauwelijks een rol te spelen bij de beoordeling van de politiek en het overheidshandelen.

Zo rond 1970 lijkt de Nederlandse regering een abonnement te hebben genomen op rapporten die haar vertellen dat zij haar taken anders moet organiseren. Sinds die tijd stromen de adviezen binnen - over de interdepartementale taakverdeling en coördinatie, over de hoofdstructuur van de rijksdienst, over de netwerken rond het openbaar bestuur, de organisatie en het management van het overheidsbedrijf, de kwaliteit van de dienstverlening. Staatscommissies, een regeringscommissaris, ambtelijke werkgroepen, tal van instanties, de WRR incluis, hebben zich erover gebogen. Aan goede voornemens geen gebrek. Betere onderlinge afstemming, meer samenhang, meer flexibiliteit, meer efficiency, meer transparantie, een betere toegankelijkheid, meer professionaliteit en eerst en vooral minder regels. Maar tegelijkertijd ook: meer inspraak, meer communicatie, meer controle en vooral veel, veel meer verantwoording.

Structuurwijzigingen passen naadloos bij het repertoire waar overheden over beschikken: (nieuwe) regelgeving en (het verleggen van) geldstromen (Frissen 1996; Van Twist 1995). In het huidige klimaat kunnen ze ook goed worden ingezet als toonbeeld van daadkrachtig optreden; in plaats van mogelijke incrementele oplossingen binnen bestaande kaders, wordt gekozen voor een nieuwe en - zo wordt gesteld - betere structuur of een effectiever systeem. Sommige van de hooggestemde aanbevelingen om overheid en politiek te moderniseren zijn inderdaad overgenomen. In de praktijk leiden zij echter zelden tot grote veranderingen. Structuurwijzigingen worden bovendien al snel een doel op zichzelf en niet een middel om bepaalde verbeteringen te realiseren. De gekozen burgemeester is daarvan een goed voorbeeld. In een ambigue context met meerdere belangen en opvattingen, zoals bij veel maatschappelijke problemen het geval is, 
leidt deze omkering van doel en middel tot het hardnekkig verdedigen van de gekozen remedie. De discussie en het debat gaan dan niet meer over de vraag of de voorgestelde structuuroplossing bijdraagt aan de oplossing, maar concentreert zich op de merites en nadelen van de voorgestelde structuuraanpassingen.

\subsection{PROBLEEMSTELLING}

Wanneer de hiervoor genoemde maatregelen niet tot oplossingen leiden en de gevoelens van onbehagen niet verlichten, is het niet vreemd dat burgers, maar ook politici en ambtenaren, een cynische blik op de overheid ontwikkelen. De vraag is echter of de verwachtingen die door de maatregelen worden gewekt wel realistisch zijn. Politiek draait om inhoudelijke en normatieve kwesties en afwegingen. Het politieke handelen wordt weliswaar door instituties en procedures geschraagd, maar mag nooit gereduceerd worden tot het volgen van de juiste regels of het blind uitvoeren van de functies die aan een bepaald orgaan nu eenmaal toebedacht zijn. Bij structuurwijzigingen staan de inhoudelijke en normatieve aspecten van politiek niet alleen steeds minder centraal, maar deze verdwijnen ook gaandeweg in de dynamiek van al dan niet gerealiseerde institutionele en procedurele hervorming. Wanneer dergelijke aspecten stelselmatig op de voorgrond treden, is de kans aanwezig dat het publieke beeld van de politiek degradeert tot dat van een machtsspel, dat men het openbaar bestuur louter nog beschouwt als banenmachine voor personen met twijfelachtige kwaliteiten, en dat politici als wereldvreemde en arrogante bestuurders worden gezien die meer geïnteresseerd zijn in spelen voor de bühne dan in het over het voetlicht brengen van de lastige maatschappelijke vraagstukken die dagelijks de samenleving treffen.

Voor de aanpak van een groot aantal van deze lastige vraagstukken zijn overheid en politiek afhankelijk van de kennis en oordelen van andere dan statelijke actoren. Vragen over de haalbaarheid, passendheid, rechtmatigheid en aanvaardbaarheid van beleid kunnen in het feitelijke politieke proces niet op één plek (qua tijd, plaats en actoren) beantwoord worden. De overheid beweegt zich bij het formuleren van beleid in een complexe omgeving. Wie in dergelijke omstandigheden een sterk vereenvoudigde probleemvoorstelling geeft, riskeert overspannen verwachtingen ten aanzien van de snelheid en effectiviteit waarmee oplossingen gedefinieerd en uitgevoerd worden, en raakt vervreemd van degenen die nodig zijn om die oplossingen te kunnen bereiken. Dit geldt in het bijzonder voor het oplossen van problemen die - op het moment waarop zij zich aandienen - met grote onzekerheden zijn behept. Het oplossen van zulke problemen kost tijd en het werk en de inbreng van velen. Het corrigeren van bestaande beleidsdoelstellingen voldoet niet. In veel gevallen is juist het formuleren van effectieve en legitieme beleidsdoelen en -middelen het voornaamste struikelblok.

De taal waarin de kritiek op het optreden van de politiek en de effectiviteit van het overheidshandelen gearticuleerd wordt is te simpel om de complexiteit van de problemen waarvoor politiek en overheid zich geplaatst te verwoorden. $\mathrm{Zij}$ 
wordt gevoed door het verlangen de politiek terug te brengen in de rol die haar in het traditionele beeld van de democratische samenleving toekomt. Politiek is daarbij de enige instantie die over beslissingen in het algemeen belang gaat en die daarom helder en duidelijk aan de kiezers moeten kunnen worden verantwoord. De processen die noodzakelijk zijn om voldoende kennis, informatie en ervaring op te doen om goede oordelen te vellen, blijven zo echter ten onrechte buiten de beschouwing (Scott 1998).

Met dit rapport wil de raad het in Bewijzen van goede dienstverlening (2004) ontwikkelde gedachtegoed verder uitwerken. In dat WRR-rapport pleitte de raad voor een systeem van checks and balances dat enerzijds recht zou doen aan het gemengde en relationele karakter van de maatschappelijke dienstverlening, dat zou inspelen op het aanwezige verbeterings- en vernieuwingspotentieel en anderzijds ook effectieve correctiemechanismen zou bevatten. De raad richtte zich daarbij op de samenwerking van onder andere instellingen, professionals, cliënten en toezichthouders in de sectoren onderwijs, arbeidsvoorziening, volkshuisvesting, welzijn en gezondheidszorg. De rol en positie van overheid en politiek bleven grotendeels buiten beschouwing. Daarin brengt de raad nu verandering door te onderzoeken hoe ook politici, ambtenaren en ministers kunnen bijdragen aan het oplossen van ingewikkelde problemen. Hiermee wil de raad de aandacht richten op het feit dat overheid en politiek nu - en in de toekomst zo mogelijk nog meer - te maken hebben met vraagstukken die anderen niet durven en kunnen aanpakken, maar die wel om een antwoord vragen. De conclusie van dit rapport zal voor bepaalde aspecten van overheid en politiek een meer generieke betekenis hebben, omdat dit soort ingewikkelde problemen zich natuurlijk niet uitsluitend in de maatschappelijke dienstverlening voordoet. Te denken valt aan de veranderingen van het klimaat waarover de raad kort geleden heeft gerapporteerd (WRR 2006), de ontwikkeling en het gebruik van biomedische wetenschappen, het beheersen van mondiale epidemieën, en de gevolgen van de vergrijzing voor de inrichting van de verzorgingsstaat.

Dit rapport voegt aan de lange reeks van adviezen over het functioneren van overheid en politiek geen voorstellen toe voor de zoveelste structuurhervorming. Het bepleit eerst en vooral dat we naar overheid en politiek op een andere manier moeten kijken dan in veel discussies hierover wordt gedaan. Die andere, en naar ons idee realistischer, blik zal er dan misschien toe leiden dat overheid en politiek - op den duur - andere dingen gaan doen, en de zaken beter gaan aanpakken. Hij zal ons in elk geval ervan kunnen weerhouden om een aantal ideeën na te jagen die slechts contraproductief werken.

Dit rapport kan dan ook gelezen worden als een verdediging van de overheid en de politiek - niet alleen tegen hun cynische critici, maar ook tegen veel van hun goed bedoelende vrienden (Crick 1962). In tegenstelling tot veel van de eerder verschenen rapporten wordt hier niet vanuit mogelijke oplossingen geredeneerd, maar staat een analyse centraal van de omstandigheden waaronder overheid en politiek moeten opereren en de problemen waarmee zij daardoor geconfronteerd 
worden. We vertrekken niet vanuit klachten over het beleid, de huidige generatie van politici, een te grote regeldruk of slecht presterende overheidsorganisaties. Niet omdat deze klachten onzinnig of allemaal onterecht zouden zijn, maar vanuit de gedachte dat ook als er niemand zou klagen - noch de burgers, noch de politici, noch de ambtenaren - er nog steeds goede redenen zijn om de plaats en functie van overheid en politiek in de hedendaagse samenleving te bespreken.

Omdat de manier waarop over overheid en politiek wordt gesproken een van de thema's vormt van dit rapport, vereisen de begrippen die hier gebruikt worden bijzondere aandacht. Het gaat hier om 'de politiek' en 'de overheid', om 'de staat' en 'het openbaar bestuur', en om 'ambtenaren', 'ministers' en 'politici'. Geen van deze termen is 'onschuldig'. De specifieke betekenis van de genoemde termen verandert in de loop van de geschiedenis, en is afhankelijk van het perspectief waaronder het politieke leven wordt bezien. In veel gevallen hebben de gebruikte termen bovendien een politieke lading en zullen de betekenissen die eraan gehecht worden verschillen al naar gelang het politieke standpunt van de auteur of de lezer. De terminologie op dit terrein wordt gevormd door essentially contested concepts - begrippen waarvan de betekenis altijd omstreden zal zijn (Gallie 1955-56). Waar in dit rapport voor een andere kijk op politiek en overheid gepleit wordt, doet zich bovendien een tweede complicatie voor. Ieder die iets nieuws voor ogen staat en daarover wil spreken, wordt veroordeeld tot het gedrag waarvoor generaals vaak zijn bekritiseerd: over strategieën te spreken die geschikt zouden zijn geweest bij de voorbereiding van de vorige oorlog. Wij kunnen vertrouwde woorden als 'politiek', 'overheid' en 'ambtenaar' in een nieuwe combinatie gebruiken en zo betekenissen proberen op te rekken, maar wie al te veel afwijkt van het gevestigde gebruik wordt onbegrijpelijk en laadt de verdenking op zich wartaal uit te slaan.

Met deze kanttekeningen voor ogen wordt in dit rapport toch gestreefd naar een zo helder en consequent mogelijk taalgebruik. Het hoofdonderwerp is het openbaar bestuur, dus het landsbestuur in de verschillende bestuurslagen, inclusief het bestuur dat wordt uitgevoerd door semi-publieke instellingen. Als over de overheid gesproken wordt, wordt het openbaar bestuur inclusief de instellingen die daarvoor in het leven zijn geroepen bedoeld. De nadruk zal vallen op de nationale overheid, maar hier en daar zullen ook andere bestuurslagen aan de orde komen. De overheid omvat dus primair de regering, het parlement, de ambtenaren op departementen en in de uitvoeringsorganisaties en de uiteenlopende andere rijksdiensten. Als over de politiek gesproken wordt gaat het hier primair over regering en parlement, hun staatsrechtelijke en feitelijke verhoudingen incluis. 'Overheid' en 'de politiek' hebben dus elementen gemeen. Dat desondanks regelmatig de frase 'politiek en overheid' wordt gebruikt is echter geen lapsus. Een van de centrale problemen waarvoor we zoals zal blijken worden gesteld, betreft het onderscheid tussen politiek en overheid (in de zin van public administration). De complexiteit van de verhoudingen maakt de genoemde frase, die dus enige redundantie bevat, noodzakelijk. 
Het heeft naar het oordeel van de raad een aantal voordelen om op een andere manier naar overheid en politiek te kijken. Het oplossen van complexe problemen vereist doorgaans de inbreng van nieuwe actoren. Die inbreng kan tot stand komen door 'laterale' acties binnen de overheid (samenwerking met andere overheidssectoren, overhevelen van een probleem naar een ander departement (bijv. drugsproblemen als een gezondheidsproblemen gaan zien)), wat de inzet mogelijk maakt van instrumenten die in andere sectoren zijn ontwikkeld. Daarnaast kan input vanuit niet-overheidsinstanties noodzakelijk zijn. Het politieke systeem (in engere zin: partijen, parlement, regering) lijkt de inbreng van nieuwe actoren echter soms in de weg te staan. Vaak moeten leerprocessen daarom door anderen gedragen worden. Deze rol ligt niet alleen bij het ambtenarenapparaat, maar ook bij deskundigen, instellingen, bedrijven en soms ook burgers. Deze actoren zijn soms beter dan politici en bestuurders in staat om problemen te definiëren en onorthodoxe oplossingen te bedenken.

Een van de kwesties die in dit rapport wordt besproken is het feit dat de inhoudelijk gedreven ambtenaar een suspecte figuur dreigt te worden en vervangen wordt door de procesmanager (zie ook Raad van State 2006). Daarnaast is sterk de nadruk op controle komen te liggen, zowel in de verhouding tussen parlement en regering, als tussen minister en departement en de diverse overheidsorganisaties. Het parlement richt zich naar de departementen en naar, vaak door de media in beeld gebrachte, kritische kiezers. Daarbij lijkt al dan niet bewust gekozen te worden voor een houding waarin het volgen voorop staat. Kennis, informatie en ervaring raken vervormd, omdat ze overwegend worden ingezet om af te rekenen in plaats van inzicht te verwerven en normatieve standpunten te ontwikkelen. Controle lijkt belangrijker te zijn geworden dan het inspireren van de overheid; het weerspiegelen van vermeende kiezersvoorkeuren gaat de plek innemen van zelfstandig politiek optreden en politieke oordeelsvorming (Andeweg en Thomassen 2003).

Een andere manier van kijken naar de complexe maatschappelijke omgeving waarin politici en ambtenaren moeten opereren maakt het niet alleen mogelijk andere ontwikkelingen te zien en deze welwillender te beoordelen, maar draagt ook bij aan een positiever beeld van politiek. Zo bezien vereist de aanpak van ongetemde problemen volgens de raad geen structuurwijzigingen, maar een investering in het vermogen van overheden en politiek om samen met anderen cognitieve en normatieve oriëntaties te ontwikkelen en bij te stellen in het licht van problemen. Het lijdt geen twijfel dat de overheid met zeer hardnekkige problemen wordt geconfronteerd waarop zij maar moeilijk een antwoord weet te formuleren. Het is niet gemakkelijk daarmee om te gaan. Politiek en overheid zullen tegenover wat in dit rapport 'ongetemde problemen' worden genoemd hun houding moeten herzien. Het bijstellen van probleemoriëntaties vereist niet alleen een ontvankelijke, nieuwsgierige en kritische benadering van problemen en de wijze waarop ze aangepakt worden, maar ook vertrouwen in het vermogen en de bereidheid van maatschappelijke actoren om bij te dragen aan oplossingen. De overheid moet leren hoe oplossingen voor complexe problemen ontwikkeld 
kunnen worden die niet alleen effectief zijn, maar ook aanspraak maken op legitimiteit.

\subsection{OPBOUW VAN HET RAPPORT}

De opbouw van dit rapport is als volgt. In hoofdstuk 2 wordt een analyse gegeven van de veranderende positie van overheid en politiek. Het krachtenveld waarbinnen overheid en politiek moeten functioneren is complex, er is sprake van tegenstrijdige eisen, de prominente rol van de media stelt nieuwe eisen aan het functioneren van politici, ambtenaren en bewindspersonen. Voor het begrijpen en oplossen is bovendien vaak de inbreng van anderen nodig. Voor het opdoen van kennis en 'oplossen' van ongetemde problemen is beleidsleren een verstandige optie. De momenteel dominante reacties op ongetemde problemen blijken echter contraproductief te kunnen uitpakken. Het ingewikkelde karakter van het werk van overheid en politiek wordt er in wezen door miskend. Door simpele oplossingen te presenteren die slecht passen bij de aard van de vragen waarmee overheid en politiek van doen hebben wordt de aard en ernst van de problemen die in het geding zijn onderschat.

Hoofdstuk 3 is meer theoretisch van aard. Wij beschrijven twee tradities van politiek: een 'verticale' en een 'horizontale' traditie. De eerste traditie wordt geassocieerd met legitiem beslissen, de tweede met redelijk besturen. In dit hoofdstuk wordt zichtbaar dat de horizontale traditie van politiek een lange geschiedenis kent en in feite ook lange tijd de dominante traditie is (geweest) binnen de Nederlandse verhoudingen. De verticale traditie is recenter en heeft zeker de laatste jaren - in ieder geval in retorische zin - een hoge vlucht genomen.

In hoofdstuk 4 keren we terug naar de praktijk. Aan de hand van verschillende voorbeelden laten we zien dat in Nederland feitelijk sprake is van een gemengd politiek bedrijf waarin gewerkt wordt met combinaties van elementen uit de verticale en horizontale traditie. De voorbeelden worden niet uitputtend behandeld, zij dienen vooral om te laten zien dat in Nederland een rijke traditie bestaat waarin geput wordt uit zowel de verticale als de horizontale traditie van politiek. Deze combinaties functioneren vooral goed als problemen en niet posities en procedures centraal worden gesteld. Het zijn als het ware pogingen om een ingewikkeld vraagstuk met een breed repertoire aan middelen aan te pakken. Binnen gemengde praktijken liggen om die reden veel mogelijkheden voor beleidsleren besloten. Die mogelijkheden zouden meer in beeld moeten komen, want ze laten zien dat voor ongetemde problemen goede oplossingen te vinden zijn. Een voorwaarde daarvoor is wel een betere inzet van ambtenaren. Natuurlijk leidt de gecombineerde aanpak van problemen ook tot de nodige vragen. De verhoudingen zijn diffuser en er is niet altijd sprake van een duidelijke verdeling van verantwoordelijkheden en bevoegdheden. De kunst is met dat soort gegevens zo te leren omgaan dat de inhoud behouden blijft en normatieve aspecten goed aan bod komen. 
Hoofdstuk 5 brengt de verschillende onderdelen van de redenering bij elkaar. We houden daarbij een pleidooi voor een probleemgerichte politiek met veel aandacht voor inhoudelijke en normatieve afweging en oordeelsvorming. De voornaamste consequenties van de redenering worden uitgewerkt in de vorm van een agenda voor ambtenaren, politici en ministers.

Met dit rapport wil de raad bijdragen aan een manier van kijken naar overheid en politiek die rekening houdt met de ingewikkelde vraagstukken waar zij in toenemende mate mee te maken krijgen. De onderbouwing van de agenda die wordt voorgesteld is gelegen in de redenering en analyse die in dit rapport worden uiteengezet. De gekozen voorbeelden zijn gebruikt als ondersteuning van de redenering en als illustratie van de wijze waarop in de praktijk reeds ervaring is opgedaan met de probleemgerichte benadering die naar het oordeel van de raad meer aandacht en navolging verdient. 


\subsection{INLEIDING}

In een parlementaire democratie behoort beleid dat wordt uitgevoerd op een gegeven ogenblik, op een welbepaalde plaats en aan de hand van vooraf vastgestelde procedures te worden verantwoord. Uitvoerende ambtenaren rapporteren aan de voor de sector verantwoordelijke bewindspersoon; de minister legt verantwoording af in het parlement; Tweede Kamerleden verantwoorden zich tegenover de kiezers als zij om een nieuw mandaat vragen. Wie zich moet rechtvaardigen over de manier waarop een zaak behandeld is en hoe en waar dat moet gebeuren, ligt in de staatsrechtelijke verhoudingen vast.

De gedachte ligt voor de hand dat de vorming van beleid dan het beste in omgekeerde richting plaats kan vinden. Zo wordt van meet af aan geanticipeerd op de latere verantwoording. De preferenties van de kiezers staan dan voorop; de gekozen volksvertegenwoordigers stemmen in onderling overleg de te volgen koers af; de regering volgt de - al dan niet bij het begin van de kabinetsperiode in een regeerakkoord vastgelegde - meerderheidsafspraken (al zal zij zich in bijzondere gevallen op haar eigen verantwoordelijkheid kunnen beroepen); het ambtelijke uitvoeringsapparaat voert de aangenomen wetten en besluiten loyaal uit. Tijdens dit hele proces kan eventueel advies worden gevraagd van deskundigen - en als dat niet gebeurt, zullen zij zich vermoedelijk ongevraagd melden. Hun rol is echter beperkt. Deskundigen mogen adviseren over de middelen die geëigend zijn om gewenste doelen te bereiken; beslissen over de doelen van handelen is echter voorbehouden aan de politiek. Als iedereen zich aan de spelregels houdt, is verzekerd dat, zoals in een democratie behoort, het volk, het demos, het beleid bepaalt en het land bestuurt. De door de overheid aangebrachte ordening in de samenleving ontleent haar legitimiteit aan het feit dat zij op de preferenties van de burgers is gebaseerd.

Dit beeld van democratie vindt een complement in de gedachte dat de verschillende fases van het beleidsvormingsproces zowel conceptueel als in de tijd te onderscheiden zijn en ook moeten zijn. Daarbij wordt impliciet een beroep gedaan op een rationeel redeneermodel waarbinnen we achtereenvolgens doelen en alternatieve handelingsopties identificeren, de mogelijke gevolgen van bepaalde beleidskeuzes voorspellen en evalueren om uiteindelijk de optie te selecteren die het meeste kans van slagen biedt voor het behalen van de eerder gestelde doelen (Stone 2002: 8-11). Het beleidsproces wordt verondersteld een lineair, eenparig voortschrijdend karakter te hebben. Bij elke volgende fase worden nieuwe elementen toegevoegd, zodat uiteindelijk, zoals bij een assemblagelijn, een afgewerkt product van de band kan rollen. De verschillende actoren kennen hun taak en plaats. Eerst is ergens sprake van agendavorming en probleemdefinitie, vervolgens belandt een kwestie bij de wetgever die eventueel met steun van externe deskundigen alternatieven voorstelt, analyseert, selecteert en verfijnt. 
De volgende stap is de implementatie door uitvoerende organen in concreet handelen. Burgers of belangengroepen die dan nog de manier waarop uitvoering wordt gegeven willen betwisten, kunnen zich tot de onafhankelijke rechter wenden. Alle delen van het beleidsproces zijn netjes gescheiden, opgedeeld en toegewezen. Het grote voordeel hiervan is dat het op elk willekeurig moment mogelijk is te bepalen in welk stadium de beleidsontwikkeling zich bevindt.

Deze ideaaltypische voorstelling van zaken staat in schril contrast met de werkelijke beleidspraktijk (Van de Donk 1997; In 't Veld 1995). In feitelijke beleidsprocessen vinden meer interacties en vormen van terugkoppeling plaats dan het lineaire model veronderstelt. De verhouding van de overheid tot de samenleving die in het genoemde model inhoudt dat de overheid door wetgeving een legitieme ordening in de samenleving schept, kan zelden alleen maar in deze termen worden beschreven. In de loop van de twintigste eeuw is het aantal overheidstaken toegenomen en is een sterke vervlechting van overheid en samenleving ontstaan, waarbij de overheid meerdere rollen is gaan spelen. Zeker, zij is in veel opzichten de regisseur van het maatschappelijk toneel; zij is op dat toneel echter ook een van de spelers wier gedrag wordt beïnvloed door de andere spelers die zich er manifesteren.

Als we democratie niet opvatten als een geheel van procedures bedoeld om de preferenties van burgers te aggregeren en tot legitieme besluitvorming te komen, maar als een specifieke manier waarop maatschappelijke problemen behandeld worden - namelijk die manier waarin uiteindelijk wat burgers vinden doorslaggevend is worden de complicaties snel zichtbaar. Dan kan om te beginnen geconstateerd worden dat de problemen die in het geding zijn zeer uiteenlopende bronnen hebben. Sommige zullen inderdaad door burgers zijn geformuleerd; andere dienen zich echter in de uitvoering van het beleid aan; weer andere komen uit de koker van deskundigen die op grond van hun expertise tot het oordeel zijn gekomen dat een onderwerp politieke aandacht behoeft; soms zullen zij zijn aangedragen door specifieke maatschappelijke groeperingen of ontstonden zij in het vuur van het politieke debat. En soms lijken de problemen uit de lucht te komen vallen. Gevraagd naar wat het moeilijkste was in de politiek, antwoordde de voormalige Engelse Prime Minister Harold MacMillan ooit simpelweg met 'events, events, events'.

Niet alleen bij de uitvoering van het beleid is de overheid afhankelijk van anderen - dat is geen nieuws -, maar dat is zij ook voor de manier waarop zij de problemen die zij geacht wordt te behandelen gepresenteerd krijgt. Haar optreden moet dan ook steeds vaker geanalyseerd en beoordeeld worden vanuit haar betrokkenheid in multi-level en multi-actor spelen. Bij de definitie van problemen en van oplossingen moet verdisconteerd worden dat zij vanuit uiteenlopende perspectieven zijn geformuleerd. Het lineaire beleidsproces dat het gangbare model van democratie suggereert, gaat uit van een neutraal verloop. Het lokaliseert de cognitieve aspecten primair in de bijdragen van 'waardevrije' deskundigen en de normatieve aspecten in de preferenties van kiezers en de manier waarop die door hun representanten worden verwoord. 
Dat hedendaagse samenlevingen in cognitief en normatief opzicht pluralistisch zijn spreekt vanzelf. Het articuleren en bijeenbrengen van die verscheidenheid zodat op basis daarvan met het gezag van de wet bindende besluiten genomen kunnen worden vereist het nodige werk. Het staatsbestel kent daarvoor tal van middelen. Door een aantal maatschappelijke ontwikkelingen lijken die middelen echter niet meer toereikend. De tekenen daarvan zijn door verschillende auteurs op uiteenlopende manieren verwoord. De veronderstelde relaties tussen beleidsingrepen, de activiteiten van de betrokken actoren en het beoogde maatschappelijke effect is structureel onbepaald en fundamenteel instabiel, betoogt Wagenaar (2005). Ankersmit (1996) duidt de huidige situatie als een 'tijdperk van onbedoelde gevolgen'. In cognitief opzicht tasten overheidsbestuurders in veel opzichten in het duister, aldus Van Gunsteren en Van Ruyven (1995), die de situatie als het besturen in 'de ongekende samenleving' typeren. Traditionele normatieve kaders blijken niet meer voldoende om uit een veelheid van meningen gezaghebbende conclusies te vormen. Habermas (1985) spreekt van een 'neue Unübersichtlichkeit', Frissen (1996) van een publiek domein dat geen inhoudelijke preferenties meer belichaamt.

Om serieus van beleid te kunnen spreken dat geacht kan worden oplossingen te bieden voor gesignaleerde maatschappelijke problemen, is het nodig dat die problemen helder en overtuigend zijn geformuleerd, dat inzicht bestaat in de normatieve aspecten ervan en dat kennis aanwezig is over de relaties tussen oorzaken en gevolgen en over de effecten van ingrepen. Om serieus op democratische manier te kunnen beslissen moeten er identificeerbare beleidsopties geformuleerd kunnen worden en moet de overtuiging bestaan dat een gekozen beleid ook daadwerkelijk kan worden uitgevoerd. Voor het functioneren van de democratie is het met andere woorden noodzakelijk dat de problemen die in het geding zijn 'politiek gedomesticeerd' worden, dat wil zeggen in beleidstermen vertaald en als opties geformuleerd worden waarover beslissingen kunnen worden genomen. Veel van de problemen waarmee de overheid feitelijk geconfronteerd wordt, kunnen echter 'ongetemd' (Churchman 1967; Rittel en Webber 1973) worden genoemd. Het kost in veel gevallen de nodige tijd, uitgebreid onderzoek, en het werk van velen voordat er van een probleem gesproken kan worden dat in termen van handelingsopties, preferenties en keuzes kan worden bediscussieerd. De overheid moet in zulke gevallen nog 'leren' wat eigenlijk het probleem is en wat haar rol bij het oplossen ervan kan zijn.

In het vervolg van dit hoofdstuk zal de aard van deze ongetemde problemen analytisch worden geëxploreerd en zullen de consequenties van het zich aandienen ervan besproken worden. Behalve op de aard van ongetemde problemen gaat dit hoofdstuk in op de manier waarop in een belangrijk deel van het huidige politieke discours op de problemen waarvoor de overheid zich gesteld ziet wordt gereageerd. Van politiek en overheid verwachten we dat zij in staat zijn uiteenlopende maatschappelijke problemen op te lossen. De vraag die in het tweede deel van dit hoofdstuk centraal staat is welke vorm die verwachting in de afgelopen decennia heeft aangenomen en hoe politiek en overheid om aan die 
verwachting te voldoen, de taken die ze geacht worden te vervullen, verstandig organiseren.

\subsection{ONGETEMDE PROBLEMEN}

Voorbeelden van ongetemde problemen zijn gemakkelijk te vinden. Ze dienen zich op verschillende beleidsterreinen aan en de verwachting is dat in de toekomst deze ongetemde problemen zich meer en indringender zullen aandienen. Wij beperken ons hier tot één voorbeeld. Andere komen in de loop van dit rapport uitgebreider ter sprake.

Toen de eerste tekenen van de aids-epidemie zich begonnen af te tekenen tastte iedereen - artsen, epidemiologen en andere volksgezondheidsdeskundigen, de ambtenaren van het ministerie van vws en ook de direct bedreigde groepen - met name homoseksuele mannen en bepaalde groepen drugsgebruikers - in het duister. Betrof het hier een ziekte die samenhing met de leefstijl van de slachtoffers en/of met drugsgebruik? Moest van een venerische ziekte worden gesproken die door een nog onbekende agent wordt overgedragen? Kon de ziekte dan ook via heteroseksuele contacten worden overgedragen en zou dus een veel groter deel van de bevolking risico lopen? Als de ziekte zich ook via heteroseksuele contacten kon verspreiden, hoe snel zou die verspreiding dan om zich heen grijpen? Wat was er eigenlijk bekend over het seksuele gedrag van de bevolking? Moest een volksgezondheidsprobleem verwacht worden van ongekende omvang en met ongekende sociale en economische (onder meer verzekerings-) consequenties? Werd de ziekte ook door bloed en bloedcontacten overgedragen en was de bloedvoorraad - en dus de meer dan duizend hemofiliepatiënten die van deze voorraad afhankelijk zijn - in gevaar? Bij elke definitie van het probleem waren verschillende groepen in het geding, moesten nieuwe vragen beantwoord worden en dienden zich specifieke normatieve vraagstukken aan - bijvoorbeeld hoe vermeden kon worden dat de ziekte, of het beleid om de verspreiding van de ziekte te voorkomen, tot discriminatie leidde, of hoe de afweging gemaakt moest worden tussen algemene volksgezondheidsbelangen en de belangen van specifieke groepen als hemofiliepatiënten.

Voordat in geval van aids van een probleem gesproken kon worden waarvoor beleidsopties geformuleerd konden worden en voordat er iets te kiezen viel, moest er onderzoek verricht worden, kennis en ervaring vergaard, en normatieve aspecten tegen het licht gehouden worden. In dat proces heeft de overheid zeker niet steeds het voortouw genomen. Wat zich aandiende was een ongetemd probleem en voor het politiek domesticeren van dat probleem bleek de Nederlandse overheid afhankelijk van vele andere actoren waaronder huisartsen, de homobeweging, de GGD (en dus de lokale overheid) en de bloedbank.

Naast gezondheidsproblemen kan worden gewezen op voedselveiligheidsvraagstukken, milieuproblemen en de maatschappelijke consequenties van nieuwe technologieën. Maar er zijn ook voorbeelden te geven van een wat traditioneler 
karakter. Ethische problemen kunnen zich ongetemd aandienen, maar ook in de sfeer van het sociaal-economisch beleid kan het zo zijn dat aanvankelijk volstrekt onbekend is hoe een probleem als een politiek probleem geformuleerd moet worden waarvoor al of niet collectieve maatregelen geëigend zijn. Toen in de jaren tachtig de werkloosheid snel opliep, diende zich bijvoorbeeld zo'n situatie aan. Pas toen werkgevers en werknemers in het zogeheten Akkoord van Wassenaar een gezamenlijke probleemdefinitie gaven, werd, zoals nog later in dit rapport besproken zal worden, beleid mogelijk dat het tij keerde.

Ongetemde problemen zijn problemen die met grote cognitieve en normatieve onzekerheden zijn omgeven. Bij zulke problemen is wel bekend dat er zich een probleem heeft aangediend, maar bestaat er onduidelijkheid over wat het probleem precies is. De meningen daarover lopen op zijn minst uiteen, de manier waarop het probleem geformuleerd en ten opzichte van andere gepositioneerd moet worden is niet duidelijk of in elk geval controversieel, over een aanpak van de problemen valt eigenlijk nog niet eens te denken - en waar dat wel gebeurt, is het risico groot dat de problemen eerder door de voorhanden oplossingen worden gedefinieerd dan dat er oplossingen voor de problemen worden gezocht. In veel gevallen is niet eens duidelijk of het om een gebrek aan kennis gaat, of dat de verschillen van mening over wat er nu precies in het geding is uit verschillende normatieve posities voortkomen. Het gebrek aan kennis heeft tot gevolg dat een weloverwogen normatieve positie lastig in te nemen is.

Wanneer we de genoemde dimensies nader opsplitsen kunnen de problemen die in het geding zijn analytisch nog wat nader worden gespecificeerd (zie figuur 1). Van domesticatie van een probleem is sprake als dat probleem langs een of andere weg van de linkerbovenhoek van deze figuur naar de rechteronderhoek wordt verplaatst. Bij zo'n verplaatsing is altijd ook sprake van een vertaling van het

\section{Figuur 1}

\section{Cognitieve zekerheid}

Klein

Groot

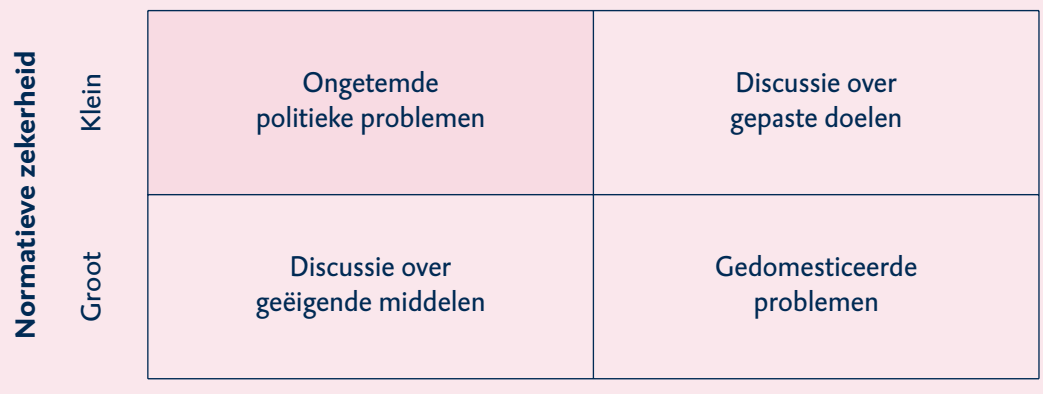

Gebaseerd op Douglas en Wildavski (1983); Hoppe (1989) en Hisschemöller (1993) 
probleem. De weg kan recht zijn, maar dat zal in vele gevallen niet de praktijk zijn. Bij domesticatie van ongetemde problemen zijn doorgaans zowel de doelen als de middelen in het geding.

Het politiek domesticeren, dus beleidsrijp maken, van problemen eist discussie, onderzoek, middelen en mankracht. Of een probleem ongetemd is of niet hangt dus vaak af van het tijdstip waarop we het probleem benaderen. Aids, dat zich aanvankelijk als ongetemd probleem aandiende, is gaandeweg gedomesticeerd en omgevormd tot een reeks van problemen waarop voorlichting en medische behandeling een oplossing konden bieden, maar waarvan ook bijvoorbeeld de verzekeringsconsequenties duidelijk geworden zijn en tot beleid hebben geleid (bijv. het moratorium van de verzekeraars waarbij een beperking van verplichte aidstests bij levensverzekeringen afgesproken is). Domesticatie is overigens niet in alle gevallen van blijvende aard. Het kan voorkomen dat problemen die in een bepaalde periode passen in de rechteronderhoek, door veranderende omstandigheden of door een ander politiek klimaat 'verhuizen' naar de linkerbovenhoek. Tot op zekere hoogte geldt dit voor het integratievraagstuk. Na 2001 kwam het thema in hevige vorm op de politieke agenda en bleek er van veel meer strijd en onwetendheid sprake te zijn dan eerst werd verondersteld.

Door de tijd die het kost om ongetemde problemen te domesticeren, dienen zulke problemen zich vaak aan als hardnekkige problemen. In veel gevallen zijn de cognitieve en de normatieve dimensies, die in figuur 1 werden onderscheiden, onderling afhankelijk. Nieuwe cognitieve inzichten kunnen de normatieve vragen doen verschuiven of soms zelfs doen verdwijnen; wanneer meer normatieve zekerheid ontstaat, kan onderzoek vaak gerichter worden ingezet om over nog hangende vragen duidelijkheid te krijgen. Gaandeweg kan de problematiek verschuiven naar andere beleidsterreinen, om andersoortige vormen van deskundigheid vragen, of normatieve vraagstukken van nieuwe aard oproepen. Gaat het bij de hardnekkige problemen in achterstandswijken om problemen van sociaaleconomische aard, zoals een hoog percentage werkloosheid, om het ontbreken van voorzieningen, de etnische diversiteit van de bevolking, of om een inmiddels achterhaald concept van ruimtelijke ordening en stadsplanning? Iedere nieuwe probleemdefinitie brengt nieuwe vragen en de noodzaak tot het mobiliseren van nieuwe typen expertise met zich mee. Wie achteraf de kronkelwegen beziet die een probleem heeft doorlopen, zal een zekere verwondering vaak niet kunnen onderdrukken: hoe komt het dat een probleem uiteindelijk op een bepaalde plek terechtkomt, dat specifieke actoren 'eigenaren' worden van het probleem en dat het probleem uiteindelijk deze specifieke vorm gekregen heeft (Gusfield 1981)?

De feitelijke behandeling van ongetemde problemen is niet alleen een veelal tijdrovend, maar ook gedistribueerd proces waaraan op verschillende tijdstippen en op verschillende plaatsen door uiteenlopende actoren bijgedragen wordt. Deze actoren brengen bovendien uiteenlopende ervaring in en bij het beoordelen van de problemen maken zij gebruik van verschillende (bijvoorbeeld disciplinaire) kaders en werken zij met andere rationaliteiten (Snellen 1987). Dat blijkt bijvoor- 
beeld al uit de aanpak van grote infrastructurele werken, het soort projecten waarover de intellectuele vaders van het begrip 'ongetemde problemen' in de jaren zeventig schreven. Politici en ambtenaren bleken niet goed in staat om grote projecten te plannen. Hun kwaliteiten als wetgever en ingenieur schoten tekort. Niet alleen was aanvullende expertise nodig van andere actoren, bijvoorbeeld sociologen, ook moesten ter plekke inschattingen gemaakt worden van de mogelijke gevolgen die aan een project, bijvoorbeeld de aanleg van een metrolijn door een grote stad, voor de bewoners verbonden waren. Omdat elk probleem weer anders bleek, moest zorgvuldig in kaart worden gebracht welke kennis daarover beschikbaar was, en of die wel of niet gebruikt kon worden. Het domesticeren van ongetemde problemen is een kwestie van beginnen en herbeginnen, onder zich steeds wijzigende omstandigheden, met nieuwe definities, actoren en middelen.

Het gedistribueerde karakter van het proces brengt bovendien met zich mee dat de beoordeling van beleid een aanzienlijk ingewikkelder aangelegenheid is dan vaak wordt gedacht. Zo'n beoordeling kan geformuleerd worden aan de hand van een viertal vragen, die door Hemerijck (2003) als richtinggevend zijn geformuleerd. Bondig geformuleerd zijn de kernvragen: Werkt het? Past het? Mag het? en Hoort het? Van een responsief beleidsbestel mag een goede aansluiting tussen instrumentele doelmatigheid, institutionele haalbaarheid en uitvoerbaarheid, constitutionele rechtmatigheid, en maatschappelijke aanvaardbaarheid worden verwacht. In het gedistribueerde beleidsproces dat zich rond ongetemde problemen ontspint, worden deze vragen echter zelden op dezelfde tijd, op dezelfde plaats en door dezelfde actoren gesteld, en de termen waarin ze gesteld worden en het kader waarmee antwoorden beoordeeld worden zullen in veel gevallen uiteenlopen. Voordat er uiteindelijk in het parlement een eindoordeel wordt gegeven, heeft zich al een gecompliceerd, inhoudelijk gestuurd proces van oordeelsvorming afgespeeld.

Vanuit het ideaaltypische model van beleidsprocessen met een nette volgorde van het formuleren van doelen, zoeken van middelen, beslissen en uitvoeren, mag het gezien de complexiteit van de feitelijke vorming van beleid over aanvankelijk - 'ongetemde' problemen eigenlijk een wonder heten dat zulke problemen ooit worden aangepakt en opgelost. Gelukkig is dat toch het geval. Aids is - althans in veel westerse landen - van een ongetemd probleem tot een hanteerbaar beleidsvraagstuk omgevormd waarvoor relatief succesvol beleid kon worden geformuleerd. De BSE-crisis is - na lange tijd een ongetemd probleem te zijn geweest -bedwongen. Het euthanasie-vraagstuk, het vraagstuk van de rechtmatigheid van stakingen, de werkloosheidsproblematiek in de jaren tachtig en het vreemdelingenbeleid uit de eerste jaren van deze eeuw zijn, zoals in hoofdstuk 4 nog in detail betoogd zal worden, voorwerp van redelijk bestuur geworden. Dat is, zoals wij zullen betogen, geen wonder, maar de uitkomst van een intelligente combinatie van verschillende vormen van politiek bedrijven. Wat het laat zien is dat het beeld van beleidsprocessen dat onder gangbare noties van democratie ligt te simpel is. De praktijk is complex, rijk en in zijn onoverzichte- 
lijkheid vaak succesvoller dan hij op het eerste gezicht lijkt te suggereren. In zijn beroemde artikel The science of "muddling through" heeft Lindblom al in 1959 gewezen op hoe wat op het eerste gezicht als "doormodderen" overkomt uiteindelijk een effectief besluitvormingsproces blijkt te zijn (Lindblom 1959 en 1965). Het is dan ook verstandig om ten aanzien van het domesticeren van sommige, hardnekkige, problemen een realistischer beeld te schetsen en daarop de vormgeving van het beleidsproces af te stemmen.

\section{3 'LERENDE OVERHEID'}

Het politiek domesticeren van ongetemde problemen is een collectief leerproces waarin de overheid een bijzondere rol speelt. Het gaat daarbij niet alleen om accommodatie en onderhandeling (Scharpf 1997). Inspraak, overleg en onderhandeling kunnen deel van uitmaken van het proces van domesticeren van problemen, maar uiteindelijk is het doel niet primair dat iedereen zijn zegje heeft kunnen doen, het bereiken van een compromis, het verbeteren van de besluitvorming of het effectiever organiseren van de informatie- uitwisseling. Het doel is het bereiken van een intelligente formulering van het probleem die zicht op een werkzame oplossing biedt. Daarvoor is een collectief 'leerproces' nodig.

De term 'leren' onderstreept dat de probleemperceptie en de cognitieve en normatieve oriëntaties bijstelling ondervinden, gericht op het inhoudelijk verbeteren van beleid. Het begrip 'leren' verdient de voorkeur boven (bijvoorbeeld) 'veranderen' of 'aanpassen'. 'Leren' heeft hierbij zowel betrekking op het beter leren zien en waarderen van wat zich reeds afspeelt als op het leren onderkennen van nieuwe mogelijkheden voor gedrag en organisatie. Het gaat daarbij dus niet om overdracht van inzichten van een autoriteit - een leraar - naar een nog onwetende leerling, maar om het gezamenlijk opdoen van ervaring, kennis en normatief inzicht die licht kunnen werpen op de 'ongetemde' problematiek en om het kritisch beoordelen daarvan. Onderzoek, veldexperimenten, systematische vergelijking van wat elders reeds bedacht, ontwikkeld of mislukt is, kunnen in dit proces een belangrijke rol spelen. Er kunnen beschikbare middelen worden beproefd en zo nodig doelen worden bijgesteld. De leerprocessen kunnen zich op uiteenlopende niveaus afspelen. In sommige gevallen bieden bestaande institutionele contexten daarvoor voldoende ruimte; in andere gevallen moeten nieuwe wegen worden gezocht. Leren veronderstelt wel een zelfkritische en open houding. Daarnaast is het van belang te vertrouwen in de toekomst en de mogelijkheid collectief omgang met onzekerheden te vinden (Heclo 1974: 305).

De overheid is niet de eerste, noch de enige organisatie die zich voor opgaven gesteld ziet waarvoor geen routineoplossingen bestaan. Dat lot deelt zij met vele anderen, en net als private organisaties zal de overheid er niet van uit kunnen gaan dat het eerste idee dat opkomt, of dat het luidst wordt verwoord, ook het beste is. Om kennis, ervaring en informatie te kunnen verzamelen en verwerken, is nodig dat overheid en politiek voldoende vertrouwen hebben in het vermogen 
en de bereidheid van burgers, experts en maatschappelijke organisaties om bij te dragen aan beleid, of dat nu de beleidsvoorbereiding of -uitvoering is. Dit betekent niet dat klakkeloos alles wordt overgenomen wat anderen voorstellen of doen. Een 'lerende overheid' is een overheid die selecteert uit maatschappelijke variatie en daarbij telkens oog houdt voor de ingewikkelde afweging van beleidsvragen en democratische waarden (Van Gunsteren 2006). Leren is geen laisser faire, het vereist zowel visie op maatschappelijke vraagstukken als op de context waarbinnen het beste aan oplossingen gewerkt kan worden.

Een 'lerende overheid' zal de tijd moeten nemen om oplossingen te formuleren, door onderzoek of experimenten gestructureerd ervaringen moeten verzamelen, mensen en ideeën bij elkaar moeten brengen en moeten zorgen voor tijdige feedback, zodat vroegtijdig van fouten kan worden geleerd. Dit betekent dat het primaat van het politieke gezag niet uitsluitend wordt aangewend om (vanuit de nationale) doorzettingsmacht te organiseren, maar ook om anderen (situationeel) de gelegenheid te geven binnen welomschreven voorwaarden nieuwe initiatieven te ontplooien, en lopende ontwikkelingen algemeen verbindend te verklaren. Een overheid die 'leert' kan - op basis van opgedane en verwerkte ervaringen problemen waarvoor zij zich gesteld ziet beter verwoorden en aanpakken dan voorheen. Zij bedient zich van een breed repertoire van besluitvormingstechnieken, schakelt deskundigheid in, mobiliseert uiteenlopende normatieve perspectieven en investeert in een zorgvuldige afweging: welk repertoire kan wanneer het beste worden ingezet en waarom.

Tot slot brengt een 'lerende overheid' een ander type argument naar voren om beleid(salternatieven) te legitimeren. Geconfronteerd met ongetemde, vaak hardnekkige problemen staat de overheid niet alleen voor de vraag met behulp van welke repertoires kennisintensieve en interdependente problemen op een effectieve manier behandeld kunnen worden. In een democratie zijn grote maatschappelijke problemen ook altijd politieke issues en niet louter managementproblemen. Zij zijn met conflicterende politieke en morele opvattingen verweven en vragen om brede menings- en oordeelsvorming. De issues zullen zich niet altijd manifesteren in de traditionele politieke arena's. Zij kunnen zich op tal van plaatsen aandienen: in uitvoeringsorganisaties, in kringen van experts, maar ook buiten de publieke sfeer. Zij moeten vaak nog publiek worden gemaakt.

Naast de vraag hoe ongetemde problemen in beleidstermen kunnen worden vertaald, staat de overheid dus in de tweede plaats voor de vraag hoe zulke problemen als politiek issue behandeld kunnen worden, in plaats van technocratisch te worden afgehandeld. Een 'lerende overheid' legitimeert haar beleidskeuzen niet uitsluitend door te verwijzen naar bestaande procedures en instituties, maar beargumenteert publiekelijk waarom zij bepaalde beslissingen neemt, en waarom zij soms niet het voortouw neemt bij het ontwikkelen van beleid, maar dat aan anderen, beter geëquipeerde actoren overlaat. Dit veronderstelt een inhoudelijk discours van beleidsmakers (Chapman 2002: 10) waarin niet alleen cognitieve en normatieve argumenten voor beleid worden gegeven, maar ook 
actief het contact wordt gezocht met belangrijke maatschappelijke actoren en met verschillende publieken (Schmidt 2003: 10). Dat brengt specifieke vereisten met zich mee voor de overheidsfunctionarissen die bij dit proces betrokken zijn. Ambtenaren, bijvoorbeeld, zullen zich moeten verantwoorden over hun opstelling in netwerken, hun informatie, de representatie van issues en het delen van verantwoordelijkheid met niet-politieke actoren (Kelly 2004: 59).

De gedachte dat de overheid moet leren introduceert een aanvullend perspectief op de politiek. Het lijdt geen twijfel dat machtsvorming en het indammen en controleren van de macht belangrijke aspecten zijn van politieke processen, ook van de beleidsvormende processen die hiervoor als 'leren' en het 'domesticeren van ongetemde problemen' zijn geduid. Zij verdienen aandacht en vereisen de aanwezigheid van uiteenlopende vormen van checks and balances. Wanneer echter uitsluitend hierop de aandacht wordt gericht, staan terugkoppelingsmechanismen al snel voorop en richt de aandacht zich vooral op de vraag of er niet uit de pas wordt gelopen. Daadwerkelijk leren vereist echter naast feedback- ook feedforward-mechanismen. Democratie mag gecontroleerd wantrouwen heten te zijn, onvoldoende vertrouwen in de actoren en het ze bij voorbaat ontnemen van de ruimte om beargumenteerd van gebaande paden af te wijken, leidt hooguit tot een herhaling van zetten. Een democratische 'lerende overheid' zal daarom een balans moeten vinden tussen enerzijds de eis dat haar beleid tegenover burgers verantwoord en gelegitimeerd moet worden, terwijl anderzijds de tijd en de ruimte genomen moeten worden om te innoveren en op een redelijke en intelligente manier 'ongetemde' problemen politiek te domesticeren en het hoofd te bieden. In de hoofdstukken 3 en 4 zal nader op deze balans worden ingegaan. Daar zal zij beschreven worden als de verhouding van wat 'verticale' en 'horizontale' politiek zal worden genoemd.

\subsection{DE HUIDIGE POLITIEKE CONTEXT; DOMINANTE REACTIES}

Beleidsleren is niet gemakkelijk. Het vereist een houding die in zekere zin haaks staat op wat momenteel van politici en overheid wordt verwacht. De moderne, assertieve burger verwacht oplossingen, daden; de politicus die voor de camera meldt dat er eerst moet worden nagedacht laadt al snel de verdenking op zich incompetent te zijn, overleg in achterkamertjes te prefereren boven openbaarheid, of commissies en rapporten te gebruiken om de zaken te traineren en verantwoordelijkheden te ontlopen. Met studeerkamergeleerden hebben de media weinig geduld; diplomatie, ooit een gewaardeerde deugd van bestuurders, wordt gewantrouwd. Ook waar politici nog geen heldere gedachten hebben, wordt van hen verwacht dat ze zeggen wat ze denken, en dan bij voorkeur in dertig seconden. Hic Rhodus, hic salta is de conditie waaronder de politiek opereert. Van politici wordt 'daadkracht' verwacht.

De rol van de media heeft het politieke bedrijf onder een enorme tijdsdruk geplaatst. De periode waarin de relatie tussen de politieke elite en het electoraat bemiddeld werd door verzuilde organisaties en geoliede partijmachines ligt 
achter ons. De politieke organisatiegraad is in de afgelopen decennia sterk afgenomen. Partijen zijn in toenemende mate organisaties geworden die bestuursfuncties verdelen, in plaats van omgevingen waarin breed en inhoudelijk over bestuur wordt overlegd. Met het ledenverlies missen politici een beslissende schakel tussen electoraat en volksvertegenwoordiging. Daardoor ontstaat onzekerheid over de achterban, het electorale voortbestaan en de inhoudelijke voorkeuren. De media hebben voor een groot deel deze mediërende rol overgenomen.

De burgers waarmee de overheid zich heeft te verstaan, ontvangen hun informatie niet langer uit - verzuilde - media, maar oriënteren zichzelf in de kakofonie van geluiden die via oude en nieuwe media klinkt. Overheid en politiek moeten zich daarom van nieuwe technieken bedienen om hun boodschap over te brengen. Alle actoren die een politieke rol spelen of willen spelen zijn afhankelijk geworden van de mate waarin en de wijze waarop kwesties en standpunten in de media naar voren gebracht en aan de orde gesteld worden. Mede door de opkomst van commerciële mediabedrijven zijn de media bovendien van karakter veranderd. De concurrentiedruk eist dat er snel gescoord wordt, en dat een groot publiek wordt bereikt. Kortom, de wegen waarlangs de betrouwbaarheid van de politieke representatie van voorkeuren en probleemvoorstellingen kon worden beproefd, zijn niet langer gegarandeerd, gezaghebbend en vanzelfsprekend (Van Gunsteren 1994: 98).

Politici moeten meer dan voorheen strijden voor stemmen en daardoor duidelijker, scherper omlijnde posities innemen over onderwerpen van maatschappelijke aandacht (Breedveld en Van Zanten 2004: 40). Doordat politieke bewegingen en ideologieën hun vanzelfsprekendheid hebben verloren, wordt persoonlijk leiderschap op een nieuwe manier zichtbaar als een zelfstandige factor in de politiek (Te Velde 2002: 13). Strijd is een belangrijkere plaats in het publieke domein gaan innemen (Van de Donk en Broeders 2004). Een gevolg is dat het politieke bedrijf voornamelijk beschreven wordt als conflictueuze activiteit en minder als succesvolle vorm van probleemoplossing. Bovendien wordt politiek, door de sterke nadruk op personen en hun onderlinge geschillen, vaak gereduceerd tot wat er in Den Haag gedaan en gezegd wordt. Het meer lokale komt hoofdzakelijk in beeld als er spanningen zijn met het nationale. Dat er in Den Haag ruim tweehonderd parlementaire journalisten rondlopen, en evenzoveel ambtenaren gespecialiseerd in communicatie en mediadeskundigen gelieerd aan politieke partijen speelt daarbij zeker een rol (Broeders en Verhoeven 2005). Vervolgens wordt deze aandacht voor Den Haag breed uitgemeten als politieke navelstaarderij.

De overheid moet bovendien optreden in een samenleving die in cultureel en dus normatief opzicht gevarieerder en gefragmenteerder is geworden. Het einde van de verzuiling, het opkomende individualisme en de aanwezigheid van aanzienlijke aantallen allochtone inwoners brengen met zich mee dat wat voorheen als vanzelfsprekend kon worden aanvaard, dat vaak al lang niet meer is. Het vertrouwen van burgers in de politiek is minder groot en minder vanzelfsprekend dan voorheen en er worden meer eisen aan het overheidsbestuur gesteld. Burgers zijn in toenemende mate van mening dat politici meer beloven dan ze kunnen waar- 
maken (Andeweg en Thomassen 2003). Dit gegeven weerspiegelt zich in de houding van politici, waarbij de laatste decennia een minder afstandelijke houding ten opzichte van kiezers is gegroeid. $\mathrm{Zij}$ zien zich steeds meer als plaatsvervanger van de kiezer dan als onafhankelijk gevolmachtigde. Tegelijk kunnen zij niet langer vertrouwen op de trouw van hun achterban en moeten ze steeds opnieuw hun positie zien te bevestigen. Het Nederlandse electoraat kent in het afgelopen decennium een historisch gesproken ongekende bewegelijkheid. Het beroep van politicus is een onrustig bestaan geworden. Door de zwevende kiezer fluctueren de verkiezingsuitslagen meer dan voorheen, wat terug valt te zien in het effect van Kamerverkiezingen op de doorstroming van politici. Vanaf begin jaren negentig werd telkens, mede door de vernieuwingen van de politieke partijen zelf, de helft van hen vervangen. Tegelijkertijd vond een verjonging plaats en werd het Kamerlidmaatschap minder een eindfunctie en meer een stap in de persoonlijke carrière (Bovend'Eert en Kummeling 2004: 82).

Behalve door een 'onbetrouwbaar' electoraat wordt het handelen van politici bovendien door specifieke ideologische ontwikkelingen beïnvloed. Toen in de loop van de jaren tachtig het neoliberalisme het politieke toneel ging beheersen, ging dat gepaard met de gedachte dat diverse traditionele overheidstaken bij publieke autoriteiten niet in goede handen zijn en dat deze beter konden worden overgelaten aan de markt. De veronderstelling daarachter was dat politici te veel geneigd zijn maatregelen te verkiezen die op korte termijn wel hun electoraat bevredigen, maar die - naar financieel-economische maatstaven gemeten - op langere termijn onverstandig zijn (Hay 2004). Behalve de zaken die de overheid geacht wordt te regelen, kreeg de politiek daardoor ook de opdracht te regelen dat diverse taken niet meer door de overheid geregeld worden. Behalve het wantrouwen van kiezers moesten politici vanaf dit moment ook de argwaan van veel economische deskundigen overwinnen. Zij werden nog steeds geacht de samenleving te besturen, maar nu wel met een hand vastgebonden op hun rug. Sinds de jaren tachtig kan bovendien worden gesproken van een tijdperk van structurele soberheid (Pierson 2001). Deze permanente budgettaire druk is mede aanleiding geweest voor een opeenvolging van hervormingen, reorganisaties en bezuinigingen binnen de rijksoverheid en sectoren van maatschappelijke dienstverlening (WRR 2004). Vanaf de jaren tachtig moest er meer met minder en werd verantwoording over vooraf gestelde doelen een belangrijk onderdeel van beleid en moest vooral beter gepresteerd worden.

Onder dit complex van omstandigheden is het politieke bedrijf een jachtige onderneming geworden waarin inhoudelijk 'leren' en de tijd nemen voor het zorgvuldig domesticeren van ongetemde problemen lastig te organiseren is. Terwijl de confrontatie met 'ongetemde' problemen om een 'lerende overheid' vraagt die de ruimte neemt om zulke problemen aan te pakken en die zich realiseert dat domesticatie van problemen werk, discussie en de inbreng van uiteenlopende ervaring vereist, is in het publieke beeld van de politiek de nadruk juist komen te liggen op snelheid, daadkracht, op direct controleerbare prestaties en 'afrekenen'. Terwijl de problemen die in het geding zijn de inzet en deskundig- 
heid van velen vereisen, is politici in dit klimaat er veel aan gelegen te beklemtonen dat alleen zij de keuzes maken en verantwoordelijk zijn - ook in die gevallen waarin daar objectief beschouwd weinig reden voor is. De kiezer moet te vriend worden gehouden, het beleid moet primair worden verdedigd als een getrouwe uitdrukking van de wensen van het electoraat en niet als een gewogen oplossing van de problemen waarmee de samenleving zich ziet geconfronteerd. Waar inhoudelijke en normatieve oriëntaties voorop zouden moeten staan, wordt de nadruk gelegd op de legitimiteit van de procedures die gevolgd zijn, wordt risicovermijdend gedrag gestimuleerd, en wordt aan routineoplossingen de voorkeur gegeven boven een nader onderzoek van de zaak die zorg verdient.

Het primaat van de politiek krijgt in deze situatie een specifieke invulling. In een vertegenwoordigende democratie behoort geen misverstand te bestaan over de vraag wie de keuzes maken en wie er uiteindelijk verantwoordelijk is. Die eis krijgt nu een specifieke vorm. Argwaan komt voorop te staan. De scepsis van de kiezer jegens de politiek wordt in het politieke bedrijf zelf doorvertaald. Parlementariërs die hun verantwoordelijkheid niet uit de weg willen gaan, zijn het als hun voornaamste taak gaan zien de regering te controleren. Dus leidt elk incident dat in de media wordt gerapporteerd tot Kamervragen. Een minister die aarzelt of zegt nog even na te moeten denken toont zo bezien slechts zwakte. Daadkracht, doortastend optreden, 'zeggen wat je denkt', is politiek succes mede gaan bepalen. Monomane, snelle en directe beslissingen uit naam van de kiezer concurreren om aandacht in de media. Informeel overleg met betrokken maatschappelijke groeperingen is als 'achterkamertjespolitiek' te boek komen te staan. Deskundigen worden op afstand gezet, overleg en advies worden strikt van elkaar gescheiden. Het ambtelijke apparaat wordt nog eens gewezen op zijn bescheiden ondersteunende en uitvoerende taken. Voortaan zijn het de kiezers in samenspraak met politici en bestuurders die bepalen wat gedaan moet worden.

Nieuwe instrumenten zoals de gekozen burgemeester en referenda worden voorgesteld en ingezet om burgers directer bij de politiek te betrekken. De aandacht gaat daarbij hoofdzakelijk uit naar een instrumentarium dat beoogt de burger als klant te bedienen: hij moet snel zijn stem kunnen laten horen en bij één loket een antwoord kunnen krijgen op al zijn vragen. Voor een groot aantal ongetemde problemen waarvoor de overheid staat biedt deze aanpak echter geen soelaas. Ongetemde problemen vragen niet om een inventarisatie van reeds bestaande meningen, maar om beter inzicht, om meer kennis en om goed verwerkte ervaring met de problematiek. Een BSE-crisis wordt niet langs de weg van een referendum opgelost, medisch-ethische vraagstukken eisen een langdurig en geïnformeerd debat, niet een loket waar kant-en-klare antwoorden kunnen worden gegeven.

De nadruk is in toenemende mate eenzijdig op procedures en het correct volgen daarvan komen te liggen. Legitimiteit wordt procedureel ingevuld. De discussies richten zich op het tijdpad, de representativiteit van vertegenwoordigers, de manier waarop verslag wordt gedaan. Transparantie, verantwoording en bestuur- 
lijke zuiverheid worden van nuttige en noodzakelijke middelen tot doelen op zich. De aandacht verschuift van de problemen die moeten worden opgelost naar de processen waarin naar oplossingen wordt gezocht. Het perspectief van de politiek verschuift daarmee van de lange naar de korte termijn. Inhoudelijke en normatieve vraagstukken ontaarden in discussies over de te volgen juiste regels.

De 'flinkheid' waarmee politici zich manifesteren kan gezien worden als een verwoede poging het primaat van de politiek te herstellen binnen een gedistribueerd beleidsproces. Dat primaat hoort in een democratie niet ter discussie te staan. Minder vanzelfsprekend is echter dat vertoon van politieke daadkracht de meest geëigende vorm is om het te bevestigen. Daadkracht veronderstelt doelen, direct in te zetten welomschreven middelen om die doelen te bereiken, en procedures om tot de juiste beslissingen te komen. Bij ongetemde problemen staan overheid en politiek wat dat betreft echter vaak geruime tijd met lege handen.

\subsection{POLITIEK-AMBTELIJKE VERHOUDINGEN}

De nadruk op daadkracht, snelheid, transparantie en het afrekenen op prestaties is in de afgelopen decennia vertaald naar een nieuwe visie op de manier waarop het overheidsapparaat dient te worden georganiseerd. Die visie staat in de internationale literatuur bekend als new public management (NPM). Het overheidsapparaat is in Nederland - en in diverse andere landen - in de afgelopen decennia langs de lijnen van deze nieuwe bestuursfilosofie gereorganiseerd. Een bestuursfilosofie die ook steeds meer het handelen van politici is gaan domineren.

NPM is regeren door te presteren, waarbij prestaties worden gemeten aan de hand van globale indicatoren. Daarnaast staat de verantwoordelijkheidstoedeling van actoren centraal. Dit gegeven leidt tot het versterken van de parlementaire democratie over de ambtelijke macht, hetgeen pregnant tot uitdrukking komt in een strikte scheiding tussen beleid en uitvoering, tussen politiek en ambtenarenapparaat en in kerndepartementen met strategische eenheden (Van der Meer en Toonen 2005: 842). NPM onderkent de complexiteit van het beleidsproces, door te streven naar het verhelderen van de onderliggende politieke en bestuurlijke structuren. Feitelijk poogt NPM daarmee het ideaaltypische lineaire beleidsmodel tot norm te verheffen. Dat zien we bijvoorbeeld als we naar de bijbehorende competenties kijken. Bij NPM horen competenties gericht op leiderschap en managementcapaciteiten geënt op het bedrijfsleven (Lodge en Hood 2005: 780). Ambtenaren moeten primair goede uitvoerders te zijn, ze behoren te beschikken over de vaardigheid vooropgezette doelen te behalen, en moeten daar zo mogelijk ook op afgerekend worden. Het vermogen problemen te duiden maakt geen onderdeel uit van hun repertoire.

NPM heeft zijn waarde bewezen als het gaat om het efficiënt organiseren van processen, het controleren van eenvoudig uit te voeren taken en het stimuleren van ondernemerschap om meer prestatiegericht te werken binnen vooropgestelde kaders. Maar wanneer doelen en middelen gaandeweg geformuleerd 
dienen te worden, schiet deze beleidsopvatting ernstig tekort. Door de strikte scheiding tussen beleid en uitvoering isoleert de politiek zich in toenemende mate van de kennis en kunde van het ambtenarenapparaat. Het gevaar dat daardoor ontstaat is dat politici zich eenzijdig gaan richten op de inhoudelijke en normatieve preferenties van kiezers. Door de procesmatige kant van het functioneren van het ambtenarenapparaat te versterken ten gunste van cognitieve competenties, raakt vervolgens ook het ambtenarenapparaat zelf geïsoleerd van het beleidsveld waarvoor het in de eerste plaats in het leven is geroepen. Het gevolg is verwaarlozing van de inhoudelijke kant van het beleidsproces en de intrede van ambtenaren die zelf niet meer inhoudelijk deskundig zijn, maar bedreven zijn in procesmanagement.

De ambtenaar krijgt in de NPM-filosofie een ondergeschikte, faciliterende en ondersteunende rol. Wie er ook gaat over inhoudelijke en normatieve afwegingen, ambtenaren zijn het in ieder geval niet. De staat wordt geacht 'leeg' te zijn. Het ambtelijk apparaat komt geen eigen inhoudelijk-normatieve rol in het publieke domein toe: het is een 'machine' die zodanig goed geolied moet zijn dat hij zijn werk doet, wanneer door de politiek op de startknop wordt gedrukt. De verantwoordelijkheid voor het bestuur ligt bij de politiek. De ambtenaar dient in deze visie aan de ene kant zijn of haar minister zoveel mogelijk uit de wind te houden en aan de andere kant het politieke proces zo goed mogelijk te laten verlopen. Bij gebrek aan voldoende doorzettingsmacht of leiderschap om een visie op problemen te poneren en oplossingen te kunnen doordrukken, wordt met een beschuldigende vinger naar het disfunctionerend ambtenarenapparaat gewezen.

De genoemde beleidsfilosofie leidt tot de nodige problemen. Allereerst zijn de politiek-ambtelijke verhoudingen flink verslechterd. Een exact beginpunt is moeilijk vast te stellen, maar in ieder geval tijdens het eerste paarse kabinet zijn daarvan door ambtenaren en bewindsvoerders de eerste tekenen waargenomen (Nieuwenkamp 2001: 349). Naarmate beleid meer omstreden is, ontstaan oplopende spanningen tussen ministers en ambtenaren en tussen departementen en uitvoeringsinstanties ('t Hart en Wille 2006: 130-131). Het versterken van het politieke primaat en de invoering van new public management lijken bovendien paradoxaal genoeg tot verzwakking van het ministeriële en departementale gezag over de implementatie en dienstverlening te hebben geleid (Hood en Peters 2004). Dit soort spanningen is weinig bevorderlijk als gezamenlijk geleerd moet worden en wederzijds vertrouwen tussen ministers en ambtenaren een voorwaarde is om tot goede resultaten te komen (Jeekel 2005).

Ten tweede wordt het wantrouwen tussen de betrokken actoren versterkt. Een centrale aanname van NPM is dat de praktijk van het menselijk handelen is doortrokken van opportunisme, list en bedrog. Daarnaast versterkt incidentenpolitiek bij politici en bestuurders de gedachte dat uitvoerders hun taken onvoldoende serieus nemen, hetgeen noopt tot de oprichting van instituties om toe te zien op een correcte uitvoering van taken. Dit geïnstitutionaliseerde wantrouwen, geba- 
seerd op het streven naar herstel van het politieke primaat, leidt tot een afrekencultuur, die op vrijwel alle vlakken resulteert in een toename van bureaucratie en allerlei vormen van risicomijdend (indek)gedrag. Binnen een dergelijke context wordt het voor overheid en politiek steeds moeilijker de noodzakelijke steun, inzet en betrokkenheid van burgers en organisaties te realiseren die nodig zijn voor goed beleid.

Belangrijker is echter dat beleidsleren binnen een dergelijk op controle, wantrouwen en snelle oplossingen gericht politiek systeem geblokkeerd wordt. Deels is dat te wijten aan het feit dat de private sector ten voorbeeld wordt gehouden aan de organisatie van de overheid, de diensten die zij levert en de wijze waarop daarover verantwoording moet worden afgelegd. Daardoor worden inherente kenmerken van de overheid en het overheidshandelen als belemmering voor efficiënt optreden beschouwd (zie ook Raad van State 2006).

Vergeleken met de private sfeer van de markt van ruilende subjecten, wordt de overheid gekenmerkt door een grote mate van institutionele verdichting. In belangrijke mate heeft die verdichting te maken met de constitutionele verankering van principes van democratische verantwoording en behoorlijk bestuur, bedoeld om te voorkomen dat de overheid haar monopolie op maatschappelijk ingrijpen in arbitraire zin zou aanwenden. Daar komen vervolgens allerlei problemen van collectieve actie bij. Politiek gedrag verschilt in velerlei opzicht van marktgedrag. Het belangrijkste verschil is het ontbreken van het efficiencyverhogende mechanisme van economische concurrentie. De verhelderende rol van prijzen, de prominentie van terugkerende interacties, het ontbreken van de noodzaak tot coördinatie, het bestaan van relatief korte causale ketens tussen keuzen en uitkomsten, versterkt het vermogen van economische actoren tot zelfcorrectie (Pierson 1994). Via het prijsmechanisme verkrijgen bedrijven onafgebroken ondubbelzinnige feedbackinformatie over hun prestaties. Hiertegenover staat dat de wereld van beleid en politiek de meetlat van de prijs ontbeert. Het is vaak onmogelijk om belangrijke aspecten van beleidsprestaties, succes en falen te observeren en te meten (March en Olsen 1995: 227).

De overheid heeft immers naast primaire taken (het realiseren van de doelen en waarden waarvoor beleid in het leven wordt geroepen), ook secundaire taken (het instandhouden van de economische, sociale en morele voorwaarden die nodig zijn voor het uitoefenen van de eerste taak) en tertiaire taken (het leveren van een bijdrage aan sociaal gedrag en publieke moraal in andere instituties en maatschappelijke sferen) (WRR 2003: 204-205). In een lege staat richt men zich vrijwel uitsluitend op het realiseren van primaire taken en gaat men voorbij aan de neveneffecten die inspanningen op de beide andere genoemde niveaus kunnen hebben. Dit doet tekort aan het besef dat politiek en overheid niet alleen procedureel correcte 'oplossingen' voor 'concrete problemen' moeten leveren, maar oplossingen moeten vinden voor problemen waarvoor inhoudelijke afweging is vereist, die uitstijgen boven de aanpak van individuele gevallen. Men negeert dat politiek erom draait inhoudelijke oplossingen te vinden voor proble- 
men waar verschil van mening over bestaat en die desondanks maatschappelijk gezag moeten verwerven. Als daadkracht van enkele individuen, groepen of organisaties, wat procedures, of het behartigen van eigen belangen zouden volstaan, zou de moeizame weg van het politiek overleg feitelijk overbodig zijn. Politiek is nodig juist waar maatschappelijke routines niet volstaan en de doelen en waarden van het beleid ter discussie staan. Juist om die secundaire en tertiaire taken naar behoren te kunnen vervullen, is het nodig blijvend te investeren in het leervermogen van overheid en politiek. De tweede en derde taak komen immers vooral in beeld als er een bereidheid is om de eigen uitgangspunten aan een onderzoek te onderwerpen en te bezien of de kaders waarbinnen wordt gewerkt wel passen bij de aard van de problemen die op een bepaald moment in het geding zijn.

\subsection{CONCLUSIE}

De overheid wordt voor 'ongetemde' problemen gesteld, waarmee zij moet leren omgaan. Elk van die ongetemde problemen is nieuw, waardoor niet zeker is welke beleidsdoelen en -middelen daaraan toegekend kunnen worden. Het proces waarin deze problemen gedomesticeerd worden, oftewel beleidsrijp worden gemaakt, vereist tijd en de inzet van velen, ook van actoren buiten de overheid zelf: deskundigen, burgers, maatschappelijke organisaties. Een effectieve en legitieme aanpak van 'ongetemde' problemen impliceert naast aandacht voor de onderlinge verhoudingen van de betrokkenen, belangen en de taken die in het geding zijn (relationeel aspect) ook een inhoudelijke benadering (substantief/normatief aspect). Een overheid die 'ongetemde' problemen oplost moet zich daarom zowel rekenschap geven van haar bijzondere positie en haar relaties met tal van andere actoren, als de inhoudelijke en normatieve complexiteit verdisconteren van de problemen waarvoor zij zich gesteld ziet. Dat betekent dat in de praktijk vragen naar de aard en de oplossing van problemen vooraf zullen moeten gaan aan de vaststelling wie voor de aanpak ervan verantwoordelijk is. Deze omkering schept andere handelingsperspectieven en brengt andere probleemdefinities naar voren. De convergentie van doelen, prestaties en beleidsoriëntaties is dan niet meer het startpunt van beleid, maar de uitkomst van door de overheid geïnitieerde samenwerking.

Het huidige politieke klimaat staat hier echter haaks op. De dominante reacties zijn contraproductief. Belanghebbenden worden gepasseerd, de kennis van uitvoerders wordt niet op prijs gesteld, deskundigheid op afstand gezet en maatschappelijke vraagstukken sterk vereenvoudigd voorgesteld. Het gevaar bestaat daardoor dat politiek vis-à-vis ongetemde problemen enerzijds een spel wordt voor de publieke bühne en anderzijds de technische uitvoering van grote reorganisaties en institutionele herzieningen en het doorvoeren van snelle en goed te communiceren oplossingen. Wanneer het antwoord op ongetemde problemen bestaat uit het afkondigen van maatregelen waarvan de effectiviteit in sommige gevallen al bij voorbaat twijfelachtig is, vervreemdt de politiek zich van maatschappelijke actoren en burgers die kennis en draagvlak kunnen scheppen voor beleid. Bestuurlijke onmacht 
en verdere erosie van politiek gezag zijn het betreurenswaardige gevolg. De lege staat wordt alleen nog maar leger, met als gevolg dat belangrijke inhoudelijke en normatieve beslissingen zonder voldoende kennis en inzicht worden doorgevoerd. Die situatie is vanuit democratisch oogpunt bezien bijzonder zorgwekkend.

Het ter discussie staan van de gedachte dat beleid in nette, conceptueel en in de tijd goed onderscheiden fases kan worden vormgegeven, heeft niet geleid tot het op onderdelen aanpassen en wellicht verwerpen van bestanddelen van dit model, maar juist tot maatregelen die de principes die eraan ten grondslag liggen moeten versterken. Dat is naar het oordeel van de raad een onjuiste weg. Naast de problemen die het NPM in de uitvoeringsorganisaties genereert, waarover in Bewijzen van goede dienstverlening (WRR 2004) reeds is gerapporteerd, heeft de gekozen aanpak en het daarmee samenhangende politieke discours waarin van politici in de eerste plaats 'daadkracht' wordt verwacht, ongewenste effecten voor het functioneren van de politiek en de democratie, vooral waar dat het domesticeren van de vele ongetemde problemen van de samenleving betreft. Toch is er geen reden tot grote wanhoop of kritiek. In feite is, zoals in de komende hoofdstukken zal worden betoogd, de praktijk rijker dan de theorie veronderstelt. Om daadwerkelijk van een lerende overheid te kunnen spreken, en een begin te maken aan het versterken van die aspecten van de politiek die kunnen bijdragen aan het domesticeren van ongetemde problemen, is het expliciteren van die praktijk als een - nooit perfecte maar redelijke - vorm van bestuur een eerste vereiste. Dat vraagt echter, zoals in het komend hoofdstuk betoogd zal worden, om een meer omvattende visie op de politiek dan de gangbare. 


\section{HORIZONTALE EN VERTICALE TRADITIE} VAN POLITIEK

\subsection{INLEIDING}

In het voorgaande hoofdstuk zijn de dominante reacties op ongetemde problemen beschreven. Aan deze reacties ligt een bepaald beeld ten grondslag over politiek. Daarbij horen tevens specifieke verklaringen voor het falen van het optreden van de politiek en de effectiviteit van het overheidshandelen. In paragraaf 3.2 zullen deze verklaringen, te weten gebrek aan deskundigheid of onvoldoende doorzettingsmacht, besproken worden. Vervolgens bespreken we in paragraaf 3.3 twee politieke tradities om het huidige, dominante beeld van politiek te nuanceren en uit te breiden met enkele waardevolle elementen. Politiek is veel rijker dan we doorgaans denken, maar zowel in het oordelen over politiek als in voorstellen tot het verbeteren van het functioneren van overheid en politiek, zoals respectievelijk in paragraaf 3.4 en $3.5 \mathrm{zal}$ worden betoogd, komt dat gegeven nauwelijks tot uitdrukking. Waar in het denken over politiek de complexiteit van het politieke bedrijf in een moderne samenleving onvoldoende wordt verdisconteerd, en overheid en politiek er niet in slagen ongetemde problemen voldoende op te lossen, bestaat de kans dat cynisme over politiek het logische sluitstuk gaat vormen.

\subsection{KLASSIEKE VERKLARINGEN VOOR HET FALEN VAN DE POLITIEK}

Op de vraag waarom de overheid minder slagvaardig is dan velen verwachten doen verschillende antwoorden de ronde. Er duiken verschillende soorten verklaringen op (Chavannes 1994; Van Doorn 1998; Toonen en Hendriks 2005), maar twee verklaringen zijn dominant: het zou politici aan deskundigheid ontbreken, of er zou sprake zijn van onvoldoende doorzettingsmacht.

De klacht dat politici de deskundigheid missen die nodig is om goed te kunnen besturen mag wel klassiek worden genoemd. Hij is reeds in Plato's Politeia te vinden. Discussiërend over de vraag of politiek een vak is introduceert Socrates daar het beeld van een schip waarvan de kapitein door een onderling ruziënde bemanning aan de kant is geschoven. Van navigeren heeft de bemanning geen verstand en zij ontkennen zelfs dat enige scholing op dit terrein nodig is.

Uiteindelijk komt degene die zich het meest populair heeft gemaakt aan het roer te staan. Na zich ook nog van de lading meester te hebben gemaakt, vaart het genootschap al drinkend en feestend zwalkend verder (Plato: 489c-497a).

Het beeld zou eeuwenlang als argument tegen democratie worden gebruikt.

Plato's mening is duidelijk. De samenleving zou bestuurd moeten worden door degene die het juiste inzicht heeft, die de waarheid kent en die weet wat goed en rechtvaardig is. Plato heeft de filosoof, de intellectueel, op het oog. Die suggestie vindt nog maar weinig weerklank. 
Plato veronderstelt dat bij de ideale bestuurder kennis over het ware en het goede in een hand verenigd zijn. Uiteindelijk gaat hij ervan uit dat beide samenvallen. Ook die veronderstelling is niet meer van deze tijd. Karakteristiek voor moderne, gerationaliseerde samenlevingen, aldus een inmiddels evenzeer klassiek argument van Max Weber (1968), is juist dat over het ware en het goede in onderscheiden instituties - namelijk wetenschap en politiek - gesproken wordt en dat daarbij verschillende standaarden een rol spelen. Wie het rationaliseringsproces niet geheel aan zich voorbij heeft laten gaan, onderkent dat tussen beide een kloof gaapt: kennis van de feiten, van wat het geval is, levert nog geen inzicht in wat het geval behoort te zijn. Terwijl rond cognitieve aangelegenheden van werkelijke deskundigheid gesproken kan worden, kan in normatieve kwesties niemand claimen de wijsheid in pacht te hebben. Daar spelen waarden, overtuigingen en morele en politieke idealen een niet te elimineren rol en daar kan niet van objectieve waarheid worden gesproken. Waar in politieke kwesties altijd ook normatieve vraagstukken een rol spelen, komt deskundigen in de politiek dan ook slechts een beperkte rol toe. Zij kunnen adviseren over efficiënte middelen, het formuleren van de juiste doelen van handelen is echter uitdrukkelijk niet hun taak. Die moeten in de politieke sfeer worden geformuleerd en in een democratische samenleving gebeurt dat op basis van een mandaat van het electoraat. Ook de evaluatie van het beleid moet door de politiek geleverd worden. De kernvragen van het beleid - werkt het, past het, mag het en hoort het? - moeten dus uiteindelijk door regering en parlement worden beantwoord, niet door deskundigen. In deze visie zijn macht en deskundigheid dus duidelijk onderscheiden, maar is hun onderlinge verhouding tegelijk nauwkeurig geregeld, waarbij de politiek het primaat toekomt.

Plato's scepsis over politici wordt in Webers visie dus niet gedeeld. Van politici worden andere dan puur cognitieve kwaliteiten gevraagd. Zij moeten visie hebben, leiderschap tonen, beslissingen durven nemen, met macht kunnen omgaan. Op een ander punt wordt Plato's gedachtegang echter wel overgenomen. Ook Weber (1988) gaat ervan uit dat het in de politiek om het besturen van het 'schip van staat', om leiderschap, gaat.

Dat leidt automatisch tot de tweede verklaring van het veronderstelde falen van het overheidsbestuur. Van een mede op basis van deskundig advies goed uitgezette koers zal alsnog weinig terechtkomen, wanneer de instructies van de kapitein niet worden opgevolgd. Politici moeten daarom ook over de nodige doorzettingsmacht beschikken om eenmaal genomen besluiten tot uitvoering te brengen. De tweede verklaring van het veronderstelde bestuurlijke onvermogen van de overheid luidt dat het hedendaagse politici hieraan ontbreekt. Wat zij ontberen is niet deskundigheid, maar doorzettingsmacht.

Deze verklaring kent twee varianten. De eerste is dat politici te weinig leiderschap tonen. Het ontbreekt hen aan charisma. Daarnaast zou de falende overheid te wijten zijn aan verstoorde relaties tussen politiek en ambtelijk apparaat. Het ideaalbeeld van de verhouding van politiek en ambtelijk apparaat dat in deze 
redenering centraal staat komt overeen met Webers klassieke theorie over de bureaucratie (1972). De taak van ambtenaren bestaat volgens die theorie uit het loyaal uitvoeren van regels die door de politiek zijn geformuleerd. De ambtenaar wordt gekenmerkt door neutraliteit, dienstbaarheid en inhoudelijke kennis van specifieke dossiers. Zo'n ambtenaar kent zijn plaats en het terrein dat hem toekomt. Hij heeft een scherp afgebakende taak en omlijnde bevoegdheden om machtsmiddelen te gebruiken en doet zijn werk binnen hiërarchische verhoudingen. Hij richt zich naar de regels en zijn handelen is voorspelbaar. Met het werk van degenen die boven hem staan, of op een andere afdeling werken, bemoeit hij zich niet. De voorspelbaarheid van de bureaucratie vormt een belangrijke waarborg tegen willekeur.

De opdracht van het ambtelijke apparaat bestaat uit loyale uitvoering van politieke besluiten. Ambtenaren zijn er in deze visie dus niet voor de vorming van beleid. Zij kunnen de politieke leiding tijdens de beleidsvoorbereiding desgevraagd vanuit hun deskundigheid adviseren, maar hun rol is dan niet anders dan die van iedere andere expert, dus beperkt. Waar sprake is van een eigenstandige rol van ambtelijke organisaties wordt die dan ook negatief gewaardeerd. Zij zou het gevaar van gebrek aan politieke controle in zich dragen. Crince le Roy (1967) sprak in dat verband zelfs van de 'vierde macht' en die uitdrukking bepaalt tot op de dag van vandaag veel discussies. Overleg en coördinatie behoort in de politieke arena plaats te vinden, niet in de ambtelijke organisatie. Voor eindeloze, tijd- en mankracht verslindende overleggen tussen ambtenaren die hun stammenstrijd uitvechten en het belang van hun dossiers verdedigen behoort geen plaats te zijn: het is aan politici om keuzes te maken, het gewicht aan een zaak toe te kennen en knopen door te hakken. Waar ambtelijke diensten zich toch bredere taken aanmeten en feitelijk eigen beleid ontwikkelen zijn de juiste verhoudingen verstoord en zijn reorganisaties geboden. Een bijkomend voordeel is dat door het schrappen van ambtelijk overleg het overheidsapparaat kan worden afgeslankt.

Ook deze tweede verklaring voor het veronderstelde bestuurlijke onvermogen van de overheid blijkt velen te overtuigen. $\mathrm{Zij}$ is, met name vanaf de jaren tachtig, verweven geraakt met zorgen over de omvang en de kosten van het overheidsapparaat. Samen hebben zij talrijke hervormingsvoorstellen geïnspireerd. De slagvaardigheid van het openbaar bestuur zou winnen door het inperken van het aantal departementen, door een meer krachtige politieke leiding, door het aan banden leggen van de contacten tussen ambtelijk apparaat en het parlement en de media en het benadrukken van de ministeriële verantwoordelijkheid. De overtuigingskracht van zulke voorstellen berust op Webers beeld van de verhouding van politiek en ambtelijk apparaat.

Dit tweede antwoord op de vraag waarom de overheid zou falen is echter gebaseerd op argumenten waarop het nodige valt af te dingen. Is het onderscheid tussen de cognitieve en de normatieve aspecten van de problemen waarvoor de overheid staat en tussen doelen en middelen wel in alle gevallen zo helder als verondersteld wordt? Kan over het onderscheid tussen beleidsvoorbereiding, 
besluitvorming en de uitvoering van beleid niet eenzelfde sceptische vraag worden gesteld? En is de metafoor van het schip van staat, waarin de rol van de politiek vergeleken wordt met die van stuurlui die een koers uitzetten om vlug en veilig de beoogde haven te bereiken, wel zo vanzelfsprekend als ze op het eerste gezicht lijkt?

Een voorbeeld waarin de genoemde vragen ontkennend beantwoord moeten worden is gemakkelijk te geven. De vraag of een nieuwe, potentieel ethisch beladen medische technologie zoals prenatale screening toegelaten moet worden en een plaats verdient in het standaard medische-voorzieningenpakket laat zich niet beantwoorden langs de weg van het achtereenvolgens verzamelen van deskundig advies, het bediscussiëren van de ethische en politieke aspecten, en het nemen van een besluit, waarna het beleid ten uitvoer kan worden gebracht (De Vries 2006). De fraaie rolverdeling die Weber presenteert blijkt in zo'n geval geen stand te houden. Die rolverdeling veronderstelt namelijk dat al duidelijk is wat in het geding is en dat over het te bereiken einddoel al in een vroeg stadium overeenstemming kan worden bereikt. Aan die voorwaarden is op het moment dat zo'n nieuwe technologie zich aandient simpelweg nog niet voldaan. Nieuwe technologieën komen met tal van onzekerheden beladen ter wereld. Voordat geadviseerd kan worden en discussies over de ethische en politieke aspecten kunnen plaatsvinden, moet eerst uitgezocht worden welke zaken precies in het geding zijn en hoe cognitieve en normatieve aspecten daarbij verdeeld zijn. Dat vereist tijd en het werk van uiteenlopende actoren.

Hoe het oordeel over zo'n nieuwe medische technologie zal uitvallen hangt immers samen met zowel de technische prestaties van de test - die zich in de loop van de tijd nog zullen ontwikkelen - als met de manier waarop de uitvoeringspraktijk gestalte krijgt. Deskundigen die vanuit verschillende disciplines werken leggen bovendien vaak uiteenlopende accenten als deze aspecten moeten worden ingeschat of geëvalueerd. Wanneer - zoals in het onderhavige geval plaatsvond de regering op zeker moment een besluit neemt dat in regelingen wordt vastgelegd waarmee het parlement instemt, is dan ook aan dat besluit een lang traject voorafgegaan waarin gaandeweg de nieuwe technologie praktisch werd gearticuleerd. Daarbij is zowel de test als de organisatie van de praktijk waarin zij gebruikt wordt geëvolueerd. De kernvragen van beleid zijn feitelijk voor een belangrijk deel op verschillende momenten, op verschillende plaatsen en door uiteenlopende betrokkenen - medische en ethische deskundigen, patiëntengroeperingen en andere direct betrokkenen zoals verzekeraars, politici en ambtenaren - beantwoord, waarbij uiteenlopende overwegingen een rol hebben gespeeld en er sprake is geweest van een voortdurende ontwikkeling van de oordeelsvorming. Ervaringen met de nieuwe technologie die in de loop van de tijd rond proefprojecten zijn vergaard en nieuwe wetenschappelijke ontwikkelingen spelen daarbij een kardinale rol (De Vries 2006).

Het openbaar bestuur heeft bovendien te maken met het feit dat het een 'product' levert dat, vergeleken met de output van de meeste private organisaties, in het 
algemeen een diffuus en algemeen karakter heeft. De vanzelfsprekende gedachte dat het overheidsbeleid gericht is op het bevorderen van de volksgezondheid vertelt nog niet wat daaronder precies moet worden verstaan. Moet de uitkomst van het beleid gemeten worden in het aantal ziektes, in het aantal zieken dat genezen wordt, of in het aantal ziektes dat voorkomen wordt? Niet alleen is de laatste doelstelling verweven met moeilijk te controleren contrafactische claims, maar ook spelen inhoudelijke kwesties een rol. Kan het voorkomen van de geboorte van kinderen met een ernstige handicap (omdat als zulke handicaps prenataal zijn opgespoord tot abortus kan worden besloten) gelden als een succes van preventiebeleid? De normatieve vraagstukken die zich aandienen zijn onontwarbaar verweven met technische kwesties. Hoe moet ondanks het aanwezig zijn van prenatale screening (door het optreden van zogeheten fout-negatieve uitkomsten) het toch geboren worden van zulke kinderen gewaardeerd worden, en hoe moet beoordeeld worden dat er (door fout-positieven) abortussen plaatsvinden van foetussen die door de screening ten onrechte als gehandicapt worden aangemerkt? Zulke vragen laten zich niet serieus beantwoorden zonder de prestaties van de diagnostiek (in termen van de percentages fout-positieven en fout-negatieven) in de beschouwing te betrekken, en die prestaties zijn in belangrijke mate afhankelijk van de stand van de medische techniek, van de manier waarop de screeningspraktijk wordt uitgevoerd en de kwaliteitscontrole en scholing van professionals plaatsvindt. Aan het begin van het traject zijn zulke kwesties in veel opzichten nog onvoorspelbaar.

Dit was uiteraard niet het soort problemen waaraan Weber dacht toen hij aan het begin van de twintigste eeuw zijn ideeën over de relatie tussen politiek en overheidsbureaucratie uiteenzette. Hedendaagse auteurs hebben zich echter wel te verstaan met het feit dat de overheid moet opereren in een samenleving die in veel opzichten 'ongekend' is en met problemen geconfronteerd wordt die wanneer zij zich aandienen met grote onzekerheden zijn omgeven (Van Gunsteren en Van Ryven 1995; Beetham 1991). Het is gebruikelijk geworden om over de hedendaagse maatschappij te spreken als een 'kennissamenleving'. Dat kan ons gemakkelijk doen vergeten dat die samenleving juist met tal van onzekerheden wordt geconfronteerd. Zij dienen zich niet alleen aan omdat ook de beste deskundigen feilbaar zijn en voor onverwachte ontwikkelingen kunnen worden gesteld. Belangrijker is dat deskundigen die vanuit verschillende disciplines werken, ambtenaren die vanuit verschillende departementen of afdelingen bij de beleidsvorming betrokken zijn, en de uiteenlopende maatschappelijke groeperingen die zich roeren, vaak sterk uiteenlopende inschattingen hebben over de problemen die in het geding zijn. In veel gevallen spelen daarbij naast technische en methodologische kwesties ook normatieve vraagstukken een rol, waarbij niet alleen de standpunten, maar ook de manier waarop de problemen geformuleerd worden sterk uiteenlopen.

Door deze onzekerheden en de verwevenheid van politieke, wetenschappelijke en uitvoeringskwesties zijn de feitelijke verhoudingen tussen experts, ambtenaren en politici rond onderwerpen vaak aanzienlijk gecompliceerder dan de fraaie 
boedelscheidingen die Weber presenteert. Ambtenaren en professionals die zowel in het voortraject als in de latere uitvoering - waarbij het onderscheid tussen beide bovendien glijdend is - een rol spelen, komen daarbij in een positie dat zij prospectieve en evaluerende vragen over het beleid moeten beantwoorden lang voordat de kwestie in het parlement en kabinet onderwerp van formele politieke besluitvorming wordt. Als de politiek zich uiteindelijk over de kwestie buigt en tot formele besluitvorming overgaat, is de praktijk dan ook vaak reeds zodanig geëvolueerd en gearticuleerd dat in veel opzichten van het vaststellen van faits accomplis gesproken moet worden.

In plaats van het beeld op te roepen van de 'koers' die door de 'stuurlui' moet worden bepaald en van door politici geformuleerde instructies die vervolgens in de ambtelijke lijn moeten worden uitgevoerd, ligt het in situaties als deze meer voor de hand van een 'maatschappelijk leerproces' te spreken waarin politiek en overheid - naast deskundigen, uitvoerders en delen van het publiek - uiteenlopende rollen spelen. Sommige problemen zijn simpelweg te groot om in een enkele adviesronde en één parlementair debat te behandelen. Zij eisen nader onderzoek, heroverweging en overleg. En dat kost tijd. De overheid die met de eerste tekenen geconfronteerd wordt van wat later zal worden aangeduid als de BSE-crisis, komt voor talloze raadsels te staan. Wat is de aard van het probleem? Gaat het exclusief om een veterinaire ziekte of is er ook de kans dat mensen gevaar lopen? Langs welke wegen vindt besmetting plaats? Wat is er bekend over de wijdvertakte internationale markten waar vee, vlees en slachtafval verhandeld worden? Wie heeft de kennis over de feitelijke praktijken in de veehouderij, de veevoederindustrie, de slachterijen? Waar kan worden ingegrepen in de complexe ketens die veehouderij en voedselindustrie verbinden om de verspreiding van de besmetting te stoppen (Oosterveer 2005)?

Deze opeenstapeling van onzekerheden typeert ook de vele andere problemen die eerder als 'ongetemde' problemen zijn aangeduid. In het weberiaanse beeld van de politiek, waarin politici het schip van staat besturen en na deskundig advies te hebben ingewonnen besluiten nemen die vervolgens ambtelijk naar de letter worden uitgevoerd, verdwijnt precies deze opeenstapeling van onzekerheden. Dat geldt ook voor de tijd, het werk dat verricht moet worden om opheldering te krijgen, de organisatie en het overleg die daarvoor nodig zijn en de ervaringen die gaandeweg moeten worden opgedaan en die verzameld en verwerkt moeten worden voordat duidelijk is wat precies in het geding is. Dat hiermee de nodige tijd gemoeid is, vormt geen blijk van bestuurlijk onvermogen. Het is inherent aan het feit dat over dergelijke problemen aanvankelijk grote onzekerheden bestaan.

De metafoor van het 'schip van staat' ontleent zijn kracht aan de gedachte dat in de politiek de haven die men wil bereiken wordt vastgesteld en dat de moeilijkheden die zich onderweg aandienen de bekende problemen van weer, wind en zeegang zijn. In veel gevallen is politiek echter een aanzienlijk complexer bedrijf dan uit Plato's metafoor en Webers nadere uitwerking van de verhouding van 
macht en deskundigheid kan worden opgemaakt. Voor de vraag of en zo ja waarom de overheid er slecht in slaagt grote, hardnekkige problemen het hoofd te bieden, doen we er dan ook goed aan een realistischer beeld te krijgen van het politieke leven dan de overgeleverde schema's die daarover bestaan suggereren. Voordat over 'falen' wordt gesproken is het verstandig helderheid te verkrijgen over wat we van politiek en overheid eigenlijk mogen verwachten.

\subsection{TWEE POLITIEKE TRADITIES}

Van politiek valt geen neutrale beschrijving te geven. Wat van politiek verwacht wordt loopt uiteen. Het begrip wordt bovendien in steeds ruimere betekenissen gebruikt voor allerlei zaken die zich op het snijvlak van conflict en coördinatie van handelen afspelen. Ook als, zoals in dit rapport, politiek primair met de overheid en met regering en parlement wordt geassocieerd, verdwijnt het inherent omstreden karakter van het begrip niet. De vraag of een maatschappelijk onderwerp een thema voor de politiek vormt en of de overheid een rol dient te spelen, zal in veel gevallen immers uiteenlopend worden beantwoord. Daarover bestaan binnen de verschillende politieke stromingen uiteenlopende ideeën. Een belangrijk deel van het politieke debat draait om dit soort vragen.

Zulke debatten hebben uiteraard vaak een specifiek inhoudelijk en niet zelden een nogal technisch karakter. Zij worden echter gevoerd tegen de achtergrond van een politiek-filosofisch vocabulaire dat zich in de loop der eeuwen heeft ontwikkeld en waarin begrippen als burgerschap, gemeenschap, gerechtigheid, recht, solidariteit, tolerantie en vrijheid zijn gemunt. Elk van de politieke stromingen maakt door eigen accenten te leggen van dit vocabulaire gebruik om uit te drukken wat zij onder het algemeen belang verstaat, om politieke idealen te verwoorden en om standpunten en keuzes te rechtvaardigen.

Het vocabulaire waarin hedendaagse politieke discussies worden gevoerd is een amalgaam van tradities. Elk van die tradities kent eigen termen en eigen stijlen van argumenteren. Doorgaans wordt er eclectisch mee omgesprongen. Zuiverheid op dit punt mag een vereiste zijn voor academische beschouwingen, in de politieke praktijk is zij vaak niet nodig en mogelijk zelfs onwenselijk (Berlin 1958: 167). Al naar gelang het onderwerp kan uit verschillende tradities worden geput om politieke zienswijzen te articuleren en standpunten te onderbouwen.

Voor de kwesties die in dit rapport behandeld worden is het echter zinvol om een onderscheid te maken tussen twee tradities die hier de 'verticale' en de 'horizontale' traditie zullen worden genoemd. Zij hebben diepe wortels in de geschiedenis van het politiek-theoretische denken en hebben in de loop van de tijd beide eigen, hedendaagse versies gekregen. De beide tradities verschillen in de manier waarop in en over politiek geargumenteerd wordt en in de manier waarop het politieke handelen geacht wordt te zijn georganiseerd. Zij komen met andere woorden beide met een eigen perspectief op de politiek en zijn met een eigen politieke praktijk geassocieerd. 
De verschillen tussen de beide tradities liggen primair op het vlak van de manier van stellen en de aanpak van problemen, niet in de politieke idealen of waarden die worden nagestreefd. Vrijheid, democratie en gerechtigheid zijn idealen die in beide tradities hooggehouden worden, al zal de precieze betekenis van de gebruikte termen verschillen en zullen de problemen die het realiseren van deze idealen in de weg staan op verschillende manieren worden gezien. In alle hoofdstromingen binnen de Nederlandse politiek zijn elementen van beide tradities terug te vinden. Het onderscheid tussen beide valt dus niet samen met het traditionele onderscheid tussen links en rechts. Dat geldt eveneens voor het in debatten van de afgelopen decennia veel gebruikte onderscheid tussen communitarisme en liberalisme (vgl. Viroli 1992; Skinner 1990; Taylor 1997). Het onderscheid tussen beide tradities overlapt verder voor een belangrijk deel met het in de recente politicologische literatuur gebruikte onderscheid tussen government en governance (Pierre en Peters 200o). Van het laatstgenoemde begrip bestaan echter talrijke omschrijvingen. In veel gevallen staan daarbij nieuwe verhoudingen tussen staat, markt en samenleving voorop. Het verschil in perspectief op de aard van politiek komt dan minder goed tot uitdrukking. Om die reden zal hier over het verschil tussen de verticale en de horizontale traditie worden gesproken.

\subsubsection{DE VERTICALE TRADITIE}

Wat wij hier de 'verticale' traditie noemen bepaalt in veel opzichten het hedendaagse, dominante beeld van de politiek. Deze traditie ontstond in de zeventiende eeuw toen de vraag gesteld werd onder welke condities een staat legitiem verplichtingen kan opleggen aan burgers. De staat waar dan over gesproken wordt is een abstracte eenheid, die niet samenvalt met het grondgebied dat wordt bestuurd, noch met de personen die er wonen, en die ook los gezien wordt van degenen die op een gegeven moment het bestuur vormen (Skinner 2002: 368; Viroli 1992).

De centrale vraag in de verticale traditie luidt waarom degene die zo'n abstracte staat bestuurt, kan beschikken over wat traditioneel koningen en prinsen toekomt, namelijk het legitieme gezag over onderdanen, dat wil zeggen de aanspraak om zonder tegenspraak te worden gehoorzaamd. Hobbes, die een van de eersten was die dit probleem formuleerde, probeerde te verklaren waarom burgers zich aan de wet moeten houden, ook als zij zelf handelingen zouden prefereren die door de staat worden verboden. Zijn doel was uit te leggen waarom, ondanks verscheidenheid van belangen en inzichten, toch eenheid moet worden geprefereerd. Bittere ervaringen met de bloedige Engelse burgeroorlogen stonden daarbij op de achtergrond.

Het antwoord, dat in het voetspoor van Hobbes werd ontwikkeld, is bekend. Het bestaat uit het idee dat individuen via een contract hun macht overdragen aan een soeverein. In de macht van de soeverein die namens hen handelt treffen zij dus een afgeleide van hun eigen macht aan. Het alternatief voor zo'n soeverein die de 
touwtjes in handen heeft zou anarchie en chaos zijn, een oorlog van allen tegen allen. Zonder een staatsgezag zou de mensheid weer in zijn natuurlijke toestand vervallen en een bestaan leiden waarin het leven - in de beroemd geworden woorden van Hobbes - "solitary, poor, nasty, brutish, and short" is.

Hobbes' voorstel behelst een normatieve, niet een empirische theorie van de politiek. Het geeft geen antwoord op de vraag hoe de maatschappelijke orde die door de staat belichaamd wordt feitelijk tot stand komt, maar zet uiteen hoe en wanneer de verhouding tussen individuen en een gegeven orde, namelijk de staat, verondersteld kan worden legitiem te zijn geregeld. Hobbes' gedachtegang is in vele varianten verder ontwikkeld en verdedigd. We vinden haar onder meer terug in de nu gangbare gedachte dat een democratische staat de legitimiteit van zijn handelen ontleent aan de procedures volgens welke burgers via vrije verkiezingen regering en of parlement kiezen. De wetten waaraan de burgers zich gebonden weten kunnen via die procedures nu immers ook geacht worden een articulatie te zijn van de wil van de burgers, of van het volk dat zij gezamenlijk vormen. Burgers die de wet gehoorzamen, gehoorzamen in die zin zichzelf.

In de verticale traditie heeft 'politiek' dus betrekking op de manier waarop de verhouding tussen staat en burgers geregeld wordt. Legitimiteit staat daarbij voorop. De relevante actoren zijn - in de hedendaagse versie - burgers die als kiezers optreden, de parlementariërs die hen representeren, de regering en het uitvoerende apparaat. Hun formele rollen en verhoudingen zijn procedureel, in het staatsrecht, vastgelegd. Er bestaat een formele keten van delegatie en verantwoording. Tussen elk van de schakels van deze keten bestaat de verhouding van principaal tot agent. Daarbij is de eerste bevoegd bindende besluiten te nemen. De laatste dient deze besluiten uit te voeren of is door de principaal gemachtigd beslissingen te nemen in zijn naam en plaats. In deze keten vindt in de ene richting delegatie van macht plaats, terwijl in omgekeerde richting sprake is van een verantwoordingsverplichting. De wetgever ontleent zo zijn macht uiteindelijk aan de kiezers; de uitvoerende macht voert uit wat de wetgever heeft besloten. De verticale traditie van denken sluit zo naadloos aan bij Webers opvattingen over de verhouding van politiek en ambtelijk apparaat. De totale keten van delegatie en verantwoording verzekert dat wat de staat uitvaardigt, geacht kan worden de uitdrukking te zijn van de wil van de kiezers of het volk. De procedures binnen de keten van delegatie en verantwoording scheppen de basis voor legitiem gezag.

\subsubsection{DE HORIZONTALE TRADITIE}

De tweede, 'horizontale' traditie van politiek denken die wij onderscheiden, is ouder dan de eerstgenoemde. Zij werd oorspronkelijk ontwikkeld in de Italiaanse steden tijdens de Renaissance en vond in de zeventiende en achttiende eeuw ook in de Nederlanden enthousiaste aanhangers (De Haan 1993; Israel 1995; Van Sas 2004; Kossman 2005). Centraal in deze traditie staat een politieke theorie over 
het besturen van een stad of staat door burgers, in plaats van door een monarch of despoot. Politiek draait hier om zelfbestuur. In de politieke filosofie staat deze traditie als 'republikanisme' te boek (Bock et al. 1990; De Haan 1993; Skinner 2002; Van Gelderen en Skinner 2002). Die term zal hier echter niet worden gebruikt. Niet het zich afzetten tegen de (klassieke, niet-constitutionele) monarchie, maar de specifieke manier waarop in deze traditie politiek wordt geconceptualiseerd staat hier voorop.

De horizontale traditie verstaat onder 'politiek' een bijzondere manier om in een samenleving orde te scheppen en gecoördineerd, gemeenschappelijk handelen mogelijk te maken. 'Politiek' wordt namelijk opgevat als die vorm van besturen waarbij expliciet het bestaan van de verscheidenheid van ervaringen, belangen en meningen die in elke samenleving aanwezig is wordt verdisconteerd. Politiek onderscheidt zich daarmee van andere manieren om maatschappelijke orde te scheppen. Zo'n orde kan immers ook door geweld worden afgedwongen of bijvoorbeeld ontstaan door de invisible hand van de marktwerking. Kenmerkend voor wat de horizontale traditie onder politieke ordening verstaat is dat er eerst geluisterd en overlegd wordt voor er algemeen bindende maatregelen worden genomen. De verscheidenheid van meningen en belangen rond een bepaalde kwestie en eventueel relevante ervaringen moeten daartoe worden gearticuleerd en op enigerlei plaats en tijd - of op meerdere plaatsen - bijeengebracht worden, zodat discussie en overleg over wat met betrekking tot die kwestie het geval is en over de gezamenlijk te volgen koers mogelijk wordt.

Politiek, aldus de horizontale traditie, vereist publieke deliberatie. De despoot die met behulp van geweld orde afdwingt overlegt niet en negeert de verscheidenheid. De markt onderkent verscheidenheid, maar ordent zonder te luisteren; op de markt wordt onderhandeld, niet overlegd. Wie politiek bedrijft, zoekt daarentegen naar een vorm van collectief handelen waarin verschillen worden overstegen of verzoend en waarin geprobeerd wordt uit te drukken wat in het algemeen belang is. Daarin ligt de opdracht van de politicus. Hij moet ervoor zorgen dat de verscheidenheid van meningen, belangen en ervaringen gearticuleerd en bijeengebracht wordt, zodat discussie en overleg mogelijk wordt die tot redelijke en rechtvaardige besluiten kunnen leiden. Dat is geen puur procedurele taak: de politicus heeft een inhoudelijke taak. Hij moet eraan bijdragen dat geschillen beslecht of overstegen worden, en dat een beleid wordt geformuleerd dat op voldoende instemming kan rekenen. In de horizontale traditie staat de kwaliteit van het bestuur voorop.

Een politiek bestuurder kan ook vanuit deze traditie bezien dus niet maar doen wat hem goeddunkt. Hij wordt beperkt in zijn handelen: hij moet met het bestaan van andere opvattingen rekening houden. Zo'n bestuurder moet daarom over bijzondere deugden beschikken - hij moet kunnen luisteren, bereid zijn van ervaringen te leren, geduld hebben, diplomatiek kunnen optreden en onkreukbaar zijn - en hij zal voor het vinden van oplossingen die bestaande verschillen verzoenen of overstijgen de nodige creativiteit aan de dag moeten kunnen leggen. 
Een politicus is in deze visie dus noch iemand die dictaten oplegt, noch iemand die domweg uitvoert wat anderen - bijvoorbeeld kiezers - willen. Hij is een scheppende kracht, een maatschappelijke innovator, die in actie komt als de gevestigde routines voor samenleven onvoldoende blijken of zich onverwacht nieuwe problemen aandienen die om collectief handelen vragen.

Deugdzaamheid zal echter niet elke bestuurder spontaan gegeven zijn. Om de politieke wijze van het scheppen van orde mogelijk te maken is dan ook een constitutie nodig waarin de grenzen van het politieke handelen expliciet zijn vastgelegd. De rechtsstaat en de rechtstatelijke beginselen vormen in deze zin een essentieel kader (WRR 2002; Witteveen en Klink 2002). Waar de grenzen van het politiek handelen niet in acht genomen worden, kan politiek immers ontaarden in despotisme.

Op de vraag welke constitutie de beste garantie voor een goed bestuur schept hebben de theoretici in de horizontale traditie verschillende antwoorden gegeven. Het onderwerp is in praktische termen ook onderwerp van uitvoerige discussie geweest in de periode waarin de Foundings Fathers de Amerikaanse constitutie ontwierpen (Madison, Hamilton en Jay 1987). Er zijn gaandeweg uiteenlopende technieken ontwikkeld om het gestelde doel te bereiken. Dat politici de grenzen niet overschrijden kan bijvoorbeeld bereikt worden door toezicht te organiseren, door hun handelingsbereik te beperken, door tegenmacht te organiseren, door een - al of niet aan verkiezingen verbonden - bestuurlijk rouleersysteem te introduceren, door bepaalde vormen van consultatie verplicht te stellen, of door verantwoording te eisen. Zulke technieken, die constituerend zijn voor een rechtsstaat, vinden we onder meer in hedendaagse rechtssystemen terug in de vorm van de trias politica, in de bescherming van de persoonlijke levenssfeer, in wettelijke procedures voor consultatie en behoorlijk bestuur, et cetera. Zij worden vanuit de horizontale traditie bezien gewaardeerd om hun effecten. Door de onafhankelijkheid van de rechter te garanderen wordt een blokkade tegen despotisme opgeworpen, aldus het fameuze argument van Montesquieu: de burger is nu niet overgeleverd aan de luimen van machthebbers, maar zal, als hij vervolgd wordt, zich kunnen verdedigen. In ieder geval in de rechtszaal zal naar de burger worden geluisterd. Het onderscheid tussen wetgevende en uitvoerende macht en andere vormen van checks and balances vervullen een vergelijkbare rol. Zulke constitutionele voorzieningen dwingen bestuurders om rekening te houden met opvattingen en belangen van anderen.

\subsubsection{DE VERTICALE VERSUS DE HORIZONTALE TRADITIE}

In de horizontale en de verticale traditie worden verschillende accenten gelegd. Hoewel voor een belangrijk deel dezelfde woorden - als staat, burger, vrijheid en bestuur - worden gebruikt, hebben die termen verschillende betekenissen al naar gelang zij in de ene of de andere traditie functioneren. Zelfs 'politiek' betekent iets anders. De kernvraag in de horizontale traditie luidt hoe het mogelijk is in verscheidenheid samen te leven en gecoördineerd te handelen; die van de verti- 
cale traditie is onder welke condities individuen de staat hebben te gehoorzamen. Politiek draait in de verticale traditie niet om het orde scheppen in verscheidenheid, maar om de legitimiteit van de macht.

De verticale en de horizontale traditie leveren dus in de eerste plaats verschillende perspectieven op de politiek. In de verticale traditie staan institutionele verhoudingen voorop en gaat de aandacht in de eerste plaats uit naar de manier waarop in die verhoudingen legitimiteit geregeld is. De horizontale traditie hanteert een perspectief waarin de politicus als scheppende actor en het politieke proces centraal staan. De legitimiteit van de uitkomsten van het handelen wordt er gesitueerd in de constitutie die de politieke handelingsruimte definieert en die moet garanderen dat uiteindelijk redelijke en rechtvaardige besluiten worden genomen.

Door dit verschil in perspectief komen andere aspecten van het politieke leven op de voorgrond respectievelijk de achtergrond te staan en worden uiteenlopende kanten van de politieke praktijk als centraal of bijkomend gewaardeerd. De beide tradities belichten dus verschillende aspecten van de politieke praktijk.

Vanuit de verticale traditie wordt het creatief beraadslagen, dat in de horizontale traditie de crux van de politiek uitmaakt, gezien als onderdeel van de voorbereidingsfase voor de besluitvorming in regering en parlement. Als de nadruk te veel op de voorbereidingsfase komt te liggen, wordt al snel in depriciërende zin van 'gedoe' of zelfs van 'achterkamertjespolitiek' gesproken. In de verticale traditie is de politicus in de eerste plaats iemand die beslissingen neemt, die knopen doorhakt en wetten uitvaardigt, die macht heeft en die daarom dient te worden gecontroleerd. Die controle vindt primair plaats door formeel toezicht en verantwoording te regelen. De plaats die de politicus binnen de keten van delegatie en verantwoording heeft, bepaalt de macht die hem toekomt en aan wie verantwoording moet worden afgelegd.

In de horizontale traditie daarentegen is de politicus vooral een bestuurder die voor de gemeenschap nieuwe vormen van samenleven en collectief handelen ontwikkelt waarin uiteenlopende belangen en inzichten worden verzoend of overstegen. Hij wordt als een creatieve kracht gezien, die over specifieke deugden moet beschikken en wiens handelen door de constitutie wordt ingeperkt. Vanuit de horizontale traditie bezien zijn de aspecten die in de verticale traditie centraal staan, activiteiten die onder specifieke omstandigheden plaatsvinden. Overleg en besluitvorming in regering en parlement zijn vanuit de horizontale traditie bezien speciale vormen van overleg, die naast andere vormen van beraadslaging plaatsvinden. $\mathrm{Zij}$ vormen in veel gevallen het sluitstuk van een politiek proces, maar zijn niet noodzakelijkerwijs de belangrijkste aspecten daarvan. Vanuit de horizontale politiek bezien vormt wat zich afspeelt binnen de formele verhoudingen die de verticale traditie naar voren schuift de afronding van de beraadslagingen, de uitslag die niet voor de wedstrijd moet worden gehouden. Vanuit de horizontale traditie bezien geeft het verticale 
perspectief een gereduceerd, gezuiverd beeld van het politieke bedrijf. Voor reacties op en oordelen over het politieke bedrijf en de maatschappelijke plaats van de overheid maakt het dus nogal uit of vanuit de verticale of de horizontale traditie wordt gekeken.

\subsection{OORDELEN OVER POLITIEK}

De beide tradities leveren elk belangrijke bestanddelen voor de manier waarop de politieke hoofdstromingen, zowel ter linker- als ter rechterzijde, hun standpunten en idealen verwoorden. In de manier waarop over overheid, burgerschap en vrijheid wordt gedacht zien we beide in wisselende mengverhoudingen terug. Verwonderlijk is dat niet. Naast het formele, zich naar het staatsrecht richtende discours dat zich aan de verticale traditie oriënteert, kent Nederland een lange horizontale, 'republikeinse', politieke traditie. In wat binnen politieke kringen wordt gezegd, klinken dus beide tradities door. Zoals in hoofdstuk 4 nog aan de orde komt hebben beide tradities ook hun weerslag op de feitelijke politieke praktijk in ons land. Politiek in Nederland is een gemengd bedrijf.

Het opvallende is echter dat zodra over politiek gesproken wordt en in algemene termen op politieke problemen - zoals het gepercipieerde falen van de overheid wordt gereageerd, dit gemengde karakter vaak uit het zicht verdwijnt. Dan staat de stijl van denken en argumenteren van de verticale traditie doorgaans voorop en raakt de horizontale traditie gemarginaliseerd. Wat de horizontale traditie benadrukt, namelijk het bestuurlijk ordenen van de samenleving, verschijnt dan als een wellicht noodzakelijk, maar niet bijzonder interessant aspect van het nemen van legitieme besluiten.

Dit komt onder meer tot uitdrukking in de hoofdstroom van de politieke wetenschappen. In de meeste politiek-wetenschappelijke paradigma's is politiek het spel om de macht. De dominantie van de verticale traditie als over politiek gesproken wordt komt verder tot uitdrukking als er in de media commentaar gegeven wordt op politieke gebeurtenissen. Legitimiteitskwesties scheppen dan het kader voor de beschouwingen: de aandacht wordt gericht op de conflicten tussen regering en parlement, op de verantwoordelijkheid van ministers voor falend beleid en incidenten. Dat lokt op zijn beurt vertoon van daadkracht bij politici uit.

Door de dominantie van de verticale traditie als over politiek wordt geoordeeld en het daarmee negeren van de politieke rol die elementen uit de horizontale traditie spelen, ontstaat een verschraald en vertekend beeld. Dat wreekt zich met name als onderwerpen ter sprake komen waarin departementsambtenaren en deskundigen een rol spelen. Door de nadruk die in de verticale traditie wordt gelegd op politiek als wilsvorming, macht en verantwoording achteraf, verdwijnt de rol van deze adviseurs, die inhoudelijk aan politiek-bestuurlijke processen bijdragen, achter de coulissen. Twee voorbeelden kunnen dat illustreren: de manier waarop over de verhouding van politici en ambtelijk apparaat wordt 
gedacht en de manier waarop gereageerd wordt op het fenomeen dat bekend is komen te staan als 'de verplaatsing van de politiek'.

Politiek omvat meer dan de keten van delegatie en verantwoording die in het staatsrecht is vastgelegd. Dat zullen ook degenen erkennen die primair geneigd zijn vanuit de verticale traditie over politiek te oordelen. Dat 'meer' wordt door hen echter primair als een aanvulling op, of afwijking van, de officiële, in het staatsrecht vastgelegde politieke verhoudingen gezien. De formele keten van delegatie en verantwoording vormt voor hen de standaard, waartegen de empirische complicaties die zich aandienen als afwijkingen worden beschreven.

Als voorbeeld kan een recent onderzoek van 't Hart et al. (2002) dienen dat de positie van departementsambtenaren en hun relaties met bewindslieden en parlementariërs analyseert. Het door de verticale traditie ondersteunde principaal-agent-model vormde in dit onderzoek het - min of meer vanzelfsprekende referentiepunt. De feitelijke, meer gecompliceerde verhoudingen van ambtenarij en politiek werden vervolgens als afwijkingen van dit model beschreven. Hoewel in dit onderzoek de vraag centraal stond hoeveel van het feitelijke politieke proces zich aan het principaal-agent-model onttrekt, werd de definitie van politiek die in dat model verankerd ligt zonder veel discussie overgenomen. Het model leverde dus enigszins paradoxaal de termen om datgene wat niet in het model past te beschrijven. Waar de verhoudingen zich voegen naar de officiële keten van delegatie en verantwoording, wordt de legitimiteit als onproblematisch aanvaard. De interessante problemen, vooral in politiek opzicht, ontstaan waar afwijkingen geconstateerd worden, bijvoorbeeld waar het beleid feitelijk door ambtenaren wordt bepaald. Een minister die dit laat gebeuren wordt door de auteurs zonder veel nadere discussie als 'zwak' gekwalificeerd.

Vanuit de horizontale traditie bezien krijgt hetzelfde fenomeen een ander gezicht. Deze traditie richt zich zoals we hebben gezien niet in de eerste plaats op de procedures die legitimiteit garanderen, maar op de kwaliteit van het bestuur. Dat heeft consequenties voor de manier waarop over de verhouding van politici en departementsambtenaren wordt gesproken. De samenleving waarmee een bestuurder zich heeft te verstaan is gevarieerd, de problemen complex. Van een goede politieke bestuurder mag dan ook verwacht worden dat hij zich niet alleen van de verschillende meningen die in het parlement klinken op de hoogte stelt, maar ook dat hij de uiteenlopende ervaringen die met een bepaalde problematiek bestaan verdisconteert. Een bewindspersoon die met een beroep op de principaal-agent-verhouding tussen bewindslieden en ambtenaren zijn eigen koers vaart en zijn oor exclusief bij parlementariërs en zijn (partij)politieke adviseurs te luisteren legt en die niet van de ervaringen en expertise die op zijn departement of in uitvoeringsorganisaties aanwezig zijn gebruik maakt, is vanuit het perspectief van de horizontale traditie bezien geen 'sterke' minister, maar in de eerste plaats een slechte bestuurder. 
Een soortgelijke observatie kan worden gemaakt waar het fenomeen besproken wordt dat bekend staat als 'de verplaatsing van de politiek'. Het gaat daarbij om het feit dat in toenemende mate voor de toekomst van de samenleving en haar burgers belangrijke besluiten genomen worden buiten de instellingen die het staatsrecht aanwijst als de legitieme plekken voor zulke beslissingen (Bovens et al. 1995). Vanuit de verticale traditie bezien gaat rond zulke gevallen de aandacht vrijwel automatisch uit naar de vraag hoe de besluitvorming en de machtsvorming die daarbij in het geding is kan worden gecontroleerd.

De vragen waartoe de verticale traditie uitnodigt zijn eenvoudig te formuleren. Hoe kunnen beslissingen die bijvoorbeeld door experts in researchinstellingen genomen worden, of in onderonsjes tussen ambtenaren, bedrijfsleven en ngo's over milieukwesties, onder democratisch toezicht worden gebracht? Hoe kan verzekerd worden dat in zulke bijeenkomsten niet alleen experts het voor het zeggen hebben, maar dat ook het algemeen belang adequaat wordt gerepresenteerd? Moeten daarvoor nieuwe procedures in het leven geroepen worden moet, met andere woorden, de keten van delegatie en verantwoording zodanig worden uitgebreid dat ook deze vormen van besluitvorming eronder gaan vallen? Of moet het democratisch toezicht juist niet naar de plekken gebracht worden waar de 'verplaatste politiek' zich afspeelt, maar moet de 'verplaatste politiek' teruggebracht worden naar de instellingen die voor de democratie waren ingericht? Moet bijvoorbeeld het parlement dusdanige ondersteuning krijgen dat het serieus kan beslissen over technische vraagstukken? Beide strategieën zijn uitgeprobeerd. Als uitwerking van de eerste optie is aanvankelijk in Denemarken en later in diverse andere landen geëxperimenteerd met zogeheten consensusconferenties waarin vroegtijdig discussies tussen experts en uiteenlopende maatschappelijke vertegenwoordigers plaatsvinden (Healy 2005). Het in 1972 in de Verenigde Staten opgerichte (maar in 1995 weer ontmantelde) Office of Technology Assessment beoogde de tweede optie te realiseren (OTA 1995). Het doel van de OTA was het Amerikaanse Congres de middelen te verschaffen die nodig zijn voor serieuze parlementaire behandeling van beleidskwesties rond belangrijke technisch-wetenschappelijke ontwikkelingen. Ook in Nederland zijn pleidooien gehouden voor een forse uitbreiding van de ondersteuning van het parlement en is het aantal stafmedewerkers per parlementariër in de afgelopen jaren uitgebreid (Wille 2005).

Net als de verhouding van politici tot hun adviserende ambtenaren komt vanuit de horizontale traditie bezien ook de 'verplaatsing van de politiek' in een ander licht te staan. Om de verscheidenheid van opvattingen en belangen te articuleren is het in moderne samenlevingen niet altijd nodig dat burgers of hun vertegenwoordigers in een vergaderzaal bijeenkomen om hun standpunten en belangen naar voren te brengen en een gezamenlijk beleid te formuleren. Moderne samenlevingen beschikken over talrijke middelen voor dit doel (Latour en Weibel 2005). Het parlement, waar gekozen representanten beraadslagen, is slechts één van die middelen. Welbewust verscheidenheid van gezichtspunten, ervaringen, belangen en meningen articuleren en bijeenbrengen en het zoeken naar gezichts- 
punten die deze verschillen overstijgen of verzoenen, vindt behalve in het parlement ook plaats in de pers en de media, in voorkomende gevallen in de rechtszaal, in instellingen waar belangenvertegenwoordigers bijeenkomen zoals de SER, in netwerken georganiseerd rondom bijvoorbeeld specifieke milieuproblemen, in adviesorganen als de Gezondheidsraad, en - iets minder evident - ook in statistisch onderzoek en in wetenschappelijke rapporten waarin overzichten worden gegeven van een bepaalde problematiek. Sinds enkele jaren kan daaraan ook het world wide web worden toegevoegd (Marres 2005: hfdst. 4).

Dat de politiek 'verplaatst' is, is vanuit de horizontale traditie bezien dus geen bijzonder verschijnsel. Opmerkelijker zou een moderne samenleving zijn die zou afzien van zulke middelen om verscheidenheid te articuleren en waarin het politiek overleg op slechts een beperkt aantal plaatsen zou zijn geconcentreerd. De feitelijke politieke praktijk laat, zoals de eerder behandelde voorbeelden van prenatale screening en aids toonden, een grote verscheidenheid zien van de plaatsen en de middelen waarmee door een grote verscheidenheid van actoren (politici, ambtenaren, wetenschapsmensen, verzekeraars, patiëntenbewegingen) aan het politieke proces wordt bijgedragen. Die rijke verscheidenheid is op zich genomen natuurlijk geen reden om te denken dat het proces vlekkeloos verloopt, dat de relevante partijen aan bod komen, en dat de diverse inzichten en standpunten adequaat gewogen en beoordeeld worden. Voor de omgekeerde reactie is echter ook geen grond. Wanneer het genoemde proces bezien wordt en problemen worden gesignaleerd, of zelfs van bestuurlijk falen wordt gesproken, is het dan ook verstandig om na te gaan of dit oordeel niet primair wordt ingegeven door het door de verticale traditie gesuggereerde gereduceerde beeld van het politieke bedrijf. Een diagnose die primair door een gereduceerd beeld wordt ingegeven, zal tot therapieën leiden die onwerkbaar zijn, als zij al geen schade aanrichten.

\subsection{VERBETERING VAN HET FUNCTIONEREN VAN OVERHEID EN POLITIEK}

De dominantie van de verticale traditie wanneer over politiek gesproken wordt is geen loutere academische aangelegenheid. Zij komt ook naar voren in de vele voorstellen die zijn gedaan tot verbetering van het functioneren van de politiek en van de overheid. In navolging van Kickert (2005) kunnen daarbij drie verschillende gebieden waarop zulke voorstellen zich richten worden onderscheiden: staatkundige verhoudingen, organisatie en management, en de ambtelijke cultuur.

Al vanaf het begin van de vorige eeuw wordt in Nederland over 'staatkundige vernieuwing' gesproken. Reeds in 1903 doen voorstellen de ronde om de Eerste Kamer af te schaffen en een referendum in te voeren. Na 1945 zijn er diverse staatscommissies geweest die zich hebben beziggehouden met grondwetsherzieningen, uitbreiding van de Tweede Kamer en vergroting van de kiezersinvloed op de beleidsvorming. Zo is in 1989 een parlementaire commissie ingesteld om te adviseren over "staatkundige, bestuurlijke en staatsrechtelijke vernieuwing". In 
het kielzog van deze commissie, naar zijn voorzitter de commissie-Deetman genoemd, is aandacht besteed aan de ministeriële verantwoordelijkheid en de zelfstandige bestuursorganen, de positie van de minister-president en de verkiezing van de burgemeester. Ook in de afgelopen kabinetsperiode stond bestuurlijke vernieuwing nog hoog op de agenda. Behalve om de gekozen burgemeester ging het over het referendum en de wijziging van het kiesstelsel. Na de weinig succesvolle poging van de afgetreden minister De Graaf is door zijn opvolger een zoveelste poging gedaan een 'democratische vernieuwingsagenda' op te stellen, onder andere door de in december 2005 ingestelde Nationale Conventie.

Voorstellen voor het verbeteren van de organisatie en het management van de rijksoverheid kennen een niet minder rijke historie. De commissie-Van Veen, de commissie-Vonhoff, de commissie-Wiegel, de regeringscommissaris voor de rijksdienst, de WRR en tal van ambtelijke werkgroepen hebben zich over deze taak gebogen (voor een overzicht zie Frissen 1996: 32). Er zijn voorstellen gedaan om de verkokering tegen te gaan en onderlinge coördinatie te bevorderen. Steeds terugkerende voorstellen zijn het instellen van kerndepartementen en het werken met coördinerend ministers en het versterken van de positie van de minister-president. In de jaren negentig is bovendien in het kader van een brede efficiency-operatie het management-denken in het openbaar bestuur geïntroduceerd. De filosofie van New Public Management heeft geleid tot de introductie van nieuwe technieken als het baten-lastenstelsel, sturen op resultaat en de nieuwe begrotingssystematiek 'Van beleidsbepaling tot beleidsverantwoording' (VBTB). Daarnaast is een belangrijke impuls gegeven aan de verzelfstandiging van uitvoerende diensten. In het kader van het project Andere overheid zijn in 2004 en 2005 de verschillende departementen gevisiteerd en is een taakanalyse van elk departement gemaakt. Het is de bedoeling dat deze taakanalyses medebepalend zullen zijn voor de toekomstige werkwijze van het rijk: "ontkokerd zonder dubbelwerk, geen stapeling van beleid, oog en oor voor de uitvoering, horizontale werkverbanden, oog en oor gericht op Brussel, flexibiliteit en maatwerk voor het oplossen van maatschappelijke problemen" (Ministerie van Binnenlandse Zaken 2004).

De verschillende commissies die adviseerden over de reorganisatie van de rijksdienst hebben ook aanbevelingen op het gebied van de ambtelijke cultuur gedaan. Deze zijn veelal van algemene aard en minder uitgebreid dan de voorgestelde structuurwijzigingen. De meest in het oog springende verandering is de instelling van de Algemene Bestuursdienst (ABD) die, naar het voorbeeld van de "civil service' in Engeland, de mobiliteit van de top moet vergroten, het esprit de corps moet versterken en verkokering tegengaan. De ABD omvat een groep topambtenaren in dienst van het rijk die "de kwaliteit, professionaliteit en de integriteit van de publieke dienst in samenspraak met het kabinet moet waarmaken" (Ministerie van Binnenlandse Zaken 1996). In eerste instantie is daarbij geprobeerd de ambtelijke professionaliteit te ontwikkelen door de toepassing van generieke Human Resource Management-instrumenten en door formulering van specifieke managementcompetenties. Daarbij is een belangrijke plaats ingeruimd 
voor procesmanagement. De filosofie van New Public Management suggereert namelijk dat de ambtelijke top niet zozeer inhoudsdeskundig moet zijn, maar over generalistische managementcompetenties dient te beschikken. De laatste jaren is er meer aandacht voor politiek-ambtelijke relaties en het beheer daarvan en voor de professionaliteit van de ambtenaar. Een helder profiel van de ambtelijke professionaliteit is er evenwel nog niet.

Al met al rijst het beeld op van een overheid die met regelmaat haar eigen functioneren ter discussie stelt en tracht te verbeteren. De verbetervoorstellen volgen elkaar in een rap tempo op. Evaluatie van vernieuwingen is beperkt en leidt maar in een beperkt aantal gevallen tot op de problemen toegesneden aanpassingen. Er wordt weinig geleerd van voorgaande analyses, voorstellen en implementaties. De resultaten stemmen niet tevreden of worden zelfs niet afgewacht. Ook nu - anno 2006 - bevinden we ons in de aanloop naar de komende verkiezingen weer in een fase van bestuurlijke drukte, met weer nieuwe voorstellen voor een slagvaardig en betrouwbaar apparaat dat minder verkokerd en doelgericht zal functioneren.

Wie het slagveld van veranderingsvoorstellen overziet komt gemakkelijk in de verleiding een strofe uit Bertolt Brechts Lied von der Unzulänglichkeit menschlichen Strebens aan te heffen:

Ja, mach nur einen Plan

Sei nur ein großes Licht!

Und mach dann noch 'nen zweiten Plan

Gehn tun sie beide nicht.

Wie deze vertwijfeling onderdrukt kan echter wel een zekere lijn vaststellen. Om te beginnen kan gesteld worden dat de overgrote meerderheid van de voorstellen uiteindelijk slechts in zeer afgeslankte vorm wordt ingevoerd. Op het moment dat de voorstellen in de politieke arena ter bespreking worden gebracht, lijken alle partijen zich in te zetten voor de afzwakking dan wel wijziging van de voorstellen. Daarbij worden compromissen gesmeed die politiek haalbaar zijn, maar waarvan niet meer wordt beoordeeld of zij ook uitvoerbaar en/of nog voldoende coherent en consistent zijn. Met name voorstellen met een expliciete normatieve en inhoudelijke lading - vooral de staatsrechtelijke voorstellen - halen het uiteindelijk niet, of alleen in een zeer afgeslankte vorm. De lotgevallen van de gekozen burgemeester of het referendum zijn exemplarisch. Het streven naar een verdere decentralisatie en het meer op afstand plaatsen van de uitvoering kunnen hier eveneens worden genoemd. Die voorstellen zijn uiteindelijk (vaak om financieeleconomische redenen) wel ingevoerd, maar een passende governance-structuur ontbreekt en uiteindelijk is er een gebrek aan overeenstemming over wat nu wel en niet en zo ja op welke manier op afstand kan worden geplaatst.

Een tweede trend die zich aftekent is dat waar wordt voorgesteld een bepaald organisatieonderdeel af te schaffen ten gunste van iets nieuws, het nieuwe in 
afgeslankte vorm wel wordt geïntroduceerd, maar het oude zelden wordt afgeschaft. Zo kan het gebeuren dat er verschillende aanvullende coördinatiemechanismen worden ingevoerd, zonder dat de bevoegdheden van de betrokken ambtelijke leiding daaraan wordt aangepast. Een veel gehoorde verzuchting is dan ook dat elk reorganisatievoorstel altijd leidt tot meer en nooit tot minder, terwijl in veel gevallen minderen juist een van de doelstellingen was. Dit mechanisme is met name zichtbaar bij de inrichting van het toezicht en de voorstellen ter verbetering ervan.

Op het gebied van management en organisatie hebben vooral de voorstellen gericht op een verdere professionalisering van procedures navolging gehad. De VBTB is hiervan een goed voorbeeld. Veel minder succesvol zijn de voorstellen die een verandering van de interne machtsverhoudingen tot gevolg hebben. Vrijwel alle voorstellen die een andere inrichting van de rijksdienst bepleiten, zoals verkleining van het aantal departementen, van het aantal ministers of van beide, zijn tot dusverre papier gebleven.

Een aantal voorstellen is wel ingevoerd. Het gaat daarbij zonder uitzondering om voorstellen gericht op de versterking van de positie van vertegenwoordigende organen en de versterking van de positie van de burger: de Nationale Ombudsman, het enquêterecht van het parlement, de dualisering van het gemeentelijk bestel.

De genoemde trends overziend kan vastgesteld worden dat bij alle veranderingsdrift die de overheid in de afgelopen decennia heeft gekenmerkt, één veronderstelling niet ter discussie heeft gestaan: de gedachte dat de verhouding tussen politiek en ambtelijke apparaat op de manier gedefinieerd moet worden die door de verticale traditie wordt gesuggereerd. Alle veranderingen zijn erop gericht de keten van delegatie en verantwoording te stroomlijnen. Voorstellen die het politieke primaat beogen te versterken hebben daarbij een relatief grote slagingskans, introductie van nieuwe technieken binnen de rijksdienst hebben ook een zekere doorwerking gehad. De verhouding tussen politiek en ambtelijke wereld zelf blijkt echter sacrosanct. De klassieke weberiaanse rolopvatting van de ambtenaar is aangevuld met het procesmanagement denken. Voor de inhoudelijke rollen die - zoals in hoofdstuk 4 nog zal blijken - ambtenaren de facto politiek en professioneel vaak spelen, is in de voorstellen echter geen plaats weggelegd. De voorstellen geven ook nauwelijks een analyse van de feitelijke veranderende rol van de ambtenaar. De verhouding tussen bewindspersoon en ambtenaar wordt niet geproblematiseerd en is er geen aandacht voor de ontwikkeling van het ambtelijke werk als gevolg van de veel bredere arena van belanghebbenden en kennisdragers waarmee de overheid te maken heeft gekregen. Over de rollen en verhoudingen die niet binnen de verticale traditie passen, wordt met andere woorden niet gesproken.

De stelling dat de hervormingsvoorstellen zich exclusief afspelen binnen de ruimte die de verticale traditie biedt vindt ondersteuning in de manier waarop in 
de opeenvolgende hervormingsvoorstellen met de maatschappelijke omgeving wordt omgegaan. Hoewel de aanleiding en noodzaak voor een herinrichting van de rijksdienst vaak buiten die dienst worden gezocht (waarbij gewezen wordt op globalisering of de toegenomen politieke rol van Europa of de interacties met tal van maatschappelijke sectoren), keert dit feit in de nadere analyses die aan hervormingsvoorstellen ten grondslag liggen zelden terug. Daarin wordt geen aandacht besteed aan de ordeningsvraagstukken die zich steeds meer op een bovennationaal niveau, of in wisselwerking met niet-overheidsinstellingen afspelen.

Waar de problemen overwegend vanuit het perspectief van de verticale traditie en het daarbij aansluitende weberiaanse perspectief worden gezien, wordt het feit dat de onderlinge verhoudingen van politiek, overheid en samenleving in de loop der tijd aanzienlijk complexer geworden zijn dan in het verleden niet verdisconteerd. De verhouding ten opzichte van Europa is wat dit aangaat tekenend. Waar een toenemend aantal beslissingen in Brussel wordt genomen, waarbij hogere ambtenaren een belangrijke rol spelen, zou verwacht mogen worden dat Haagse voorstellen gericht op het verbeteren van het overheidsfunctioneren daarmee rekening houden. In het vigerende debat over de verbetering van de rijksdienst is daarvan echter nauwelijks iets te merken. De voorstellen van en vooral de discussie over de staatssecretaris voor Europese Zaken zijn voorbeelden van de manier waarop deze bovennationale inbedding versmald wordt tot een vraag van taakverdeling en positionering van bewindslieden. Het feit dat Nederland onderdeel is van de Europese Unie en dat in toenemende mate belangrijke dossiers een Europese dimensie hebben en nieuwe typen van deskundigheid vragen, vertaalt zich niet in een andere oriëntatie van het ambtelijk apparaat, noch in voorstellen waarin de repercussies daarvan voor de rol van ambtenaren wordt verdisconteerd. De Europese aspecten van het beleid blijven de taak van afzonderlijke afdelingen van departementen; de issues die daar behandeld worden veelal als technische vraagstukken afgedaan, de feitelijke rol die internationale netwerken van ambtenaren en technische deskundigen spelen bij de vorming van Europees beleid en de repercussies die dat heeft voor de nationale politiek blijven buiten beschouwing. Als over politiek en overheid wordt nagedacht is Europa nog steeds ver weg.

\subsection{CONCLUSIE}

Binnen de Nederlandse politiek wordt gewerkt vanuit perspectieven waarin de beide in het voorgaande onderscheiden tradities van politiek doorklinken. Voor het verwoorden en rechtvaardigen van standpunten wordt van een vocabulaire gebruik gemaakt waarin noties uit zowel de verticale als de horizontale traditie een rol spelen. Zodra over politiek gesproken wordt, neemt de dominantie van de verticale traditie echter toe en dreigt de horizontale traditie uit het zicht te verdwijnen. Legitimiteitsvraagstukken en het toezicht op de macht komen dan in het centrum van de aandacht te staan. De kernvragen van het beleid worden geacht te worden beantwoord door een zeer beperkt aantal actoren, die een vaste 
plaats hebben in de keten van delegatie en verantwoording die in de verticale traditie de ruggengraat van het politieke bestel vormt. Alles wat niet binnen dit schema past wordt gezien als (problematische) afwijking, als ondermijning van het primaat van de politiek, of op zijn best als stappen die aan de echte politiek voorafgaan. Klassieke leerstukken als het onderscheid tussen advisering en besluitvorming, en de waardevrijheid die de rol van wetenschappelijke experts beperkt tot het aanreiken van middelen, terwijl de keuze van doelen het prerogatief van de politiek zijn, en de met procedurele competenties aangevulde klassieke opvatting van de rol van de ambtenaar, zouden de voorwaarden moeten scheppen voor een juiste boedelscheiding en de correcte definitie van het domein van de politiek. Deze leerstukken berusten echter meer op wishful thinking dan op een serieuze analyse van wat feitelijk plaatsvindt.

Door het politieke leven primair vanuit de verticale traditie te bezien ontstaat een verarmd beeld, dat onze waardering van de politiek en haar rol in de samenleving beperkt. Dit beïnvloedt de oplossingen voor gepercipieerde tekortkomingen van de politiek. Ongenoegen over de kwaliteit van het beleid en het bestuur wordt automatisch vertaald in voorstellen voor het stroomlijnen van de keten van delegatie en verantwoording, in procedurele voorstellen, in het maximaliseren van het toezicht, in de invoering van referenda, het inrichten van websites om de communicatie tussen burgers, politici en overheid te verbeteren, et cetera. Ook de verhoudingen tussen politiek en ambtelijk apparaat worden vanuit dit perspectief eenzijdig beschouwd en voorzien van de bijpassende voorstellen tot verbetering.

Wat vervolgens aan wensen overblijft, kan in deze manier van denken dan alleen nog worden verwoord door een weinig precieze en weinig overtuigende klaagzang over 'ontbrekend leiderschap'. Als de oorzaak van het veronderstelde falen van de overheid niet aan gebrek aan deskundigheid geweten kan worden, en de maatregelen om de doorzettingsmacht van politici door reorganisaties van de rijksdienst te vergroten zijn uitgeput, kan immers nog maar één betrokkene de schuld krijgen: de politicus. Waar in het denken over politiek de verticale traditie domineert en de complexiteit van het politieke bedrijf in een moderne samenleving onvoldoende wordt verdisconteerd, is cynisme over politiek het logische sluitstuk. Dat cynisme leidt tot een gevaarlijke erosie van de democratie. 


\section{POLITIEK IN NEDERLAND: GEMENGD BEDRIJF}

\subsection{VERTICALE EN HORIZONTALE ASPECTEN VAN DE NEDERLANDSE POLITIEK}

De horizontale en verticale tradities die in het voorgaande hoofdstuk zijn onderscheiden maken van oudsher deel uit van het Nederlandse politieke landschap (Lendering 2005). Om idealen te verwoorden en standpunten in concrete politieke kwesties te onderbouwen wordt door alle politieke hoofdstromen gebruik gemaakt van noties uit beide tradities. Hun rol blijft echter niet beperkt tot woorden en perspectieven. Ook in de manier waarop het politieke handelen is ingericht spelen beide tradities een rol. Er is in dit opzicht in Nederland sprake van een 'gemengd bedrijf'.

Om te beginnen komen we elementen van beide tradities tegen in geformaliseerde bestuurlijke arrangementen. In de verhouding tussen regering en parlement, en in de verhouding tussen wetgevende en uitvoerende macht, staat de verticale traditie voorop. Binnen de overheid zijn echter ook allerlei sectoren aan te wijzen waarin het horizontale beginsel van zelfsturing prominent aanwezig is. De waterschappen en het hoger onderwijs zijn hiervan voorbeelden. Ook in de beginselen van behoorlijk bestuur die in de Algemene Wet Bestuursrecht zijn vastgelegd vinden we de horizontale traditie terug. De in Nederland van oudsher aanwezige horizontale traditie kleurt ook de informele politieke omgangsvormen. Bijvoorbeeld wanneer er ongenoegen wordt geuit over een kabinet dat zich op het formele standpunt stelt dat het een Kamermeerderheid achter zich weet en zich daarom niet met anderen - bijvoorbeeld de vakbeweging - hoeft te verstaan.

Participatie van actoren die buiten de statelijke keten van delegatie en verantwoording opereren is een onderscheidend kenmerk van het Nederlandse politieke bestel. Volgens sommigen is het zelfs een vrucht van de horizontale traditie die vanaf de zeventiende eeuw deel uitmaakt van de Nederlandse politieke landschap (Daalder 1989). Op veel beleidsterreinen is sprake van een sterk vervlochten beleidsruimte. Georganiseerde belangen ontmoeten elkaar in overleg- en adviesorganen en delen samen met politieke gezagbekleders en topambtenaren kennis en macht. Een dergelijke vorm van geïnstitutionaliseerde beleidsvervlechting is bijvoorbeeld te vinden op het sociaal-economische terrein.

Niet in alle gevallen zijn de gegeven institutionele voorzieningen echter toereikend. De voorbeelden van aids in hoofdstuk 2 en prenatale screening in hoofdstuk 3 laten zien dat, wanneer nieuwe problemen zich aandienen, veel zo niet alle betrokkenen met grotendeels lege handen staan. Om te kunnen participeren moet je vooraf weten wat je wilt, of de ruimte krijgen om uit te zoeken wat je betrokkenheid bij het betreffende probleem is. Het domesticeren van problemen leidt dan ook vaak tot heel nieuwe organisaties en institutionele structuren. 
Behoedzaamheid bij de participatie van niet-statelijke actoren is uiteraard op zijn plaats. De wijze waarop netwerken van betrokkenen ontstaan waarin ervaringen, belangen en meningen geordend worden, moet evenzeer ter discussie staan als de besluitvorming in regering en parlement.

Omdat in het denken over politiek de verticale traditie vooropstaat, wordt er doorgaans met een zekere vanzelfsprekend van uitgegaan dat de - in de verticale traditie geconcipieerde - staat het omvattende kader vormt voor vormen van horizontale politiek. Waar horizontale elementen zijn geïncorporeerd (bijvoorbeeld zelfbestuur voor een bepaalde publieke sector), wordt dit dan ook verondersteld plaats te vinden binnen 'verticaal' geregelde wettelijke kaders. Horizontale elementen worden geacht een aanvulling te bieden op de kaders en regelingen die hun primaire legitimiteit ontlenen aan de keten van politieke principaal-agentverhoudingen. Uiteindelijk berust de zeggenschap echter bij de verantwoordelijke minister. Voorbeelden zijn gemakkelijk te vinden. De Wet op het Hoger Onderwijs en Wetenschappelijk Onderzoek gunt de universiteiten een zekere bestuurlijke autonomie, ook waar de uitvoering van de taken van de universiteiten en hogescholen voor een belangrijk deel uit rijksmiddelen wordt bekostigd en de minister tal van bevoegdheden en verantwoordelijkheden houdt. In de Sociaal-Economische Raad (SER) wordt overlegd en over economie en werkgelegenheid geadviseerd; uiteindelijk is het echter aan regering en parlement om te besluiten of de SER-adviezen worden overgenomen.

Dat de verticale traditie het kader vormt voor elementen van de horizontale traditie spreekt echter niet vanzelf. Er zijn belangrijke voorbeelden te noemen waarin de verhoudingen feitelijk anders liggen en horizontale elementen al aan bod komen voordat langs verticale weg kaders daarvoor zijn gecreëerd. Ook op nationaal niveau doen zich politieke processen voor waarin het horizontale beginsel de leidraad vormt. 'Politiek' duidt in zulke gevallen dan niet in de eerste plaats op de manier waarop legitieme beslissingen worden genomen, maar op een vorm van besturen of maatschappelijk ordenen waarin expliciet geprobeerd wordt de verscheidenheid van belangen, opvattingen en ervaringen te verdisconteren. Daartoe moeten uiteenlopende meningen, belangen en ervaringen worden gearticuleerd en bijeengebracht. De 'bestuurders' die daarbij in het geding zijn ontlenen hun gezag niet aan een plaats in de officiële keten van principaal-agentverhoudingen of aan de gevolgde procedures, maar aan de kwaliteit van hun bestuurlijke werk. Ze trachten creatieve oplossingen te vinden voor problemen die expliciet als aangelegenheden van algemeen belang worden gezien. Vanuit de verticale traditie bezien zijn zij zelfs geen politici. Strikt genomen wordt vanuit deze traditie bezien politiek bedreven op de verkeerde plaats. Het loont echter de moeite dat snelle normatieve oordeel op te schorten en enkele voorbeelden eens preciezer te bezien.

Een eerste voorbeeld is reeds in hoofdstuk 3 ter sprake gekomen, namelijk de vorming van het beleid op het terrein van prenatale screening. Lang voordat er door regering en parlement besluiten werden genomen, vond al uitvoerig beraad 
over deze nieuwe technologie plaats en werd geëxperimenteerd met de introductie ervan. In dat proces kreeg het overgrote deel van het beleid op dit terrein vorm. Daarmee was de nodige tijd, organisatie en overleg gemoeid. De inzet was vereist van uiteenlopende actoren en de wisselwerking tussen medische onderzoekers, ethici en juristen, ambtenaren en politici. Voordat er binnen de instellingen die de verticale traditie als de legitieme plaatsen voor politiek handelen aanwijst van 'besluiten' gesproken kon worden, moest eerst nog duidelijk worden wat in het geding was. Dat duidt niet automatisch op het falen van de democratie of op bestuurlijk onvermogen. Gezien de onzekerheden die lange tijd met prenatale screening verbonden waren moest voor er een serieus oordeel kon worden gegeven eerst ervaring worden opgedaan.

In de nu volgende paragrafen zullen eerst enkele voorbeelden behandeld worden waarin zich, rond uiteenlopende problemen, overeenkomstige processen hebben afgespeeld en een dialoog tot stand is gekomen tussen verschillende actoren. In veel gevallen leidde dat niet alleen tot betere uitkomsten, maar ook tot een grotere bereidheid de genomen besluiten te aanvaarden. De voorbeelden worden niet inhoudelijk uitputtend behandeld; zij worden hier gepresenteerd als illustraties van de wijze waarop combinaties van elementen uit de verticale en horizontale traditie functioneren. Na het bespreken van deze voorbeelden zal nader worden ingegaan op de voordelen van deze combinaties en op de mogelijke spanningen die ook kunnen ontstaan.

\subsubsection{DE EUTHANASIEPROBLEMATIEK}

Het eerste voorbeeld betreft de ontwikkeling van de euthanasiewetgeving. Tot op heden stelt het Wetboek van Strafrecht euthanasie en de hulp bij zelfdoding strafbaar. In de loop der jaren zijn echter zorgvuldigheidseisen geformuleerd waarmee getracht wordt recht te doen aan de kwestie die naar huidig oordeel in het geding is. Indien aan deze zorgvuldigheidseisen wordt voldaan, wordt niet tot strafvervolging overgegaan.

De genoemde zorgvuldigheidseisen zijn, vanaf de zogeheten zaak Eindhovense arts (1952), in opeenvolgende rechterlijke oordelen tot stand gekomen. Een belangrijke rol daarbij hebben de bijdragen van de Inspecteur voor de Volksgezondheid gespeeld die in de zaak Postma (1973) als getuige-deskundige optrad. Daarnaast hebben onder meer de Nederlandse Vereniging voor Vrijwillige Euthanasie (NVVE) en de Koninklijke Nederlandse Maatschappij tot bevordering der Geneeskunst (KNMG) actief bijgedragen aan de rechtsontwikkeling rond euthanasie. Er is bovendien door tal van individuele deskundigen - ethici, juristen en medici - in de loop der jaren over de problematiek en de opeenvolgende rechterlijke uitspraken gepubliceerd. In een proces dat enkele decennia heeft geduurd zijn de aspecten die bij de euthanasiekwestie in het geding zijn gearticuleerd. Gaandeweg is duidelijker geworden wat rond deze kwestie in het geding is. Daarbij hebben behalve ethische en juridische overwegingen ook de ervaringen in de medische praktijk een belangrijke rol gespeeld. De plaats waar de uiteenlopende 
articulaties van de problematiek bijeen werden gebracht en waar - in de vorm van het formuleren van zorgvuldigheidseisen - expliciet naar bestuurlijke oplossingen die geacht konden worden het algemeen belang uit te drukken werd gezocht is niet het parlement, het kabinet of het ministerie, maar de rechtszaal geweest.

Pas in de jaren tachtig verplaatste de euthanasiediscussie zich naar politiek Den Haag. De kabinetten-Lubbers I en II slaagden er echter niet in om de veranderende opvattingen om te zetten in wetgeving. De Raad van State oordeelde dat het in dit stadium onmogelijk was om inhoudelijke normen te formuleren voor het wettelijk toestaan van euthanasie. De Raad achtte het wenselijk de jurisprudentie af te wachten (Strijers 2003: 30-3). Expliciet werd dus afgezien van het soort politieke beleids- en besluitvorming dat vanuit de verticale traditie bezien zou mogen worden verwacht. Onder de kabinetten-Kok I en II werd de strafuitsluitingsgrond in het Wetboek van Strafrecht ingevoerd (art. 293, tweede lid), waardoor artsen die voldaan hadden aan de zorgvuldigheidseisen niet meer strafbaar waren onder het Nederlandse strafrecht. Daarnaast werd een meldings- en toetsingsprocedure vastgesteld. Dit heeft geleid tot de Wet toetsing levensbeëindiging op verzoek en hulp bij zelfdoding.

De principiële vraag of euthanasie onder voorwaarden aanvaardbaar is, werd niet langs de lijn van de verticale politiek, maar via jurisprudentie beantwoord. De rechter heeft daarbij de rol gespeeld die in de horizontale traditie aan politieke bestuurders wordt toegewezen. Staatsrechtelijk, vanuit de verticale traditie redenerend, past die rol de rechter uitdrukkelijk niet. Hoewel niet constitutioneel gedekt, is de rechter in deze zaak echter opgetreden zoals in de horizontale traditie van een goed bestuurder mag worden verwacht: er is geluisterd, er is rekening gehouden met ervaringen, en er is door de ontwikkeling van zorgvuldigheidscriteria een creatieve oplossing gevonden voor een buitengewoon lastig maatschappelijk probleem. Vervolgens konden gezaghebbende conclusies getrokken worden. Toen de Haagse politiek zich uiteindelijk over de euthanasiekwestie boog, konden de vruchten daarvan worden geplukt. Door de latere wetgeving verwierf het in de rechtszaal ontwikkelde beleid democratische legitimiteit.

Omdat de euthanasiepolitiek lange tijd buiten de Haagse keten van delegatie en verantwoording heeft plaatsgevonden, kon bij het schrijven van de wetgeving behalve van de - sterk verdeelde - gegeven meningen binnen de verschillende politieke partijen ook van de langs de weg van de jurisprudentie gestructureerde ervaringen gebruik worden gemaakt. De combinatie van en wisselwerking tussen een publieke discussie (zij het hoofdzakelijk beperkt tot de kringen van uiteenlopende professionals) en gezaghebbende rechterlijke uitspraken hebben tot een kwalitatieve ontwikkeling van de meningsvorming geleid. Door de rol die de horizontale politieke traditie heeft gespeeld, leerde de Nederlandse samenleving als het ware om te gaan met de morele kwesties bij euthanasie. Dat wil uiteraard niet zeggen dat iedereen met het bereikte resultaat zal instemmen, noch dat de wet die uiteindelijk is aangenomen in alle opzichten onberispelijk is. De Nederlandse euthanasiewetgeving heeft zoals bekend in het buitenland soms verbijste- 
ring gewekt en over de uitvoeringspraktijk worden ook in Nederland de nodige vragen gesteld.

Door de rol die de rechter in deze kwestie heeft gespeeld lijkt echter een kwalitatief niveau van wetgeving en uitvoeringspraktijk te zijn gerealiseerd, dat niet mogelijk zou zijn geweest als de politieke behandeling van de euthanasiekwestie zich alleen had afgespeeld in de gremia die vanuit de verticale traditie daarvoor zijn aangewezen. De rechter heeft een creatieve, politieke rol gespeeld. Hij heeft een context geschapen voor redelijk overleg waarin inhoudelijke verdieping van de problematiek mogelijk bleek en in de vorm van zorgvuldigheidseisen de weg gesuggereerd naar een verzoening van standpunten. Die rol had misschien ook door anderen of langs andere wegen kunnen worden vervuld. Wellicht had intensief beraad in professionele kring of een zorgvuldig gevoerd maatschappelijk debat tot dezelfde verdieping geleid. Dat er bij ingewikkelde kwesties ruimte gemaakt moet worden voor 'horizontale' politiek, impliceert dan ook niet dat de rechterlijke macht de eerstaangewezene zou zijn voor deze politieke rol. Zoals uit later te behandelen voorbeelden blijkt, kan deze rol ook elders worden belegd.

\subsubsection{STAKINGSRECHT}

Dat horizontale politiek zich niet beperkt tot controversiële kwesties op het terrein van de ethiek, maar zich ook kan uitstrekken naar onderwerpen die doorgaans geassocieerd worden met macht en harde economische belangen, kan duidelijk worden wanneer als tweede voorbeeld de ontwikkelingen rond het stakingsrecht in Nederland worden beschouwd. Ook op dit terrein heeft een deel van het politieke proces zich in de rechtszaal afgespeeld. Maar ook andere plaatsen en actoren zijn van belang geweest in het bijeenbrengen, verwoorden en wegen van argumenten.

Hoewel het thema zeker ook de aandacht van de ('verticale') politiek heeft gehad, zijn vooral de werkgeversorganisaties en vakbeweging de leidende actoren in de discussie over dit thema geweest. Een voorstel van de staatscommissie-CalsDonner (1967) om het stakingsrecht een plaats te geven in de grondwet heeft geen gevolg gehad. De feitelijke vormgeving van het (niet in wetgeving vastgelegde) stakingsrecht heeft in Nederland primair plaatsgehad langs de weg van rechterlijke uitspraken. Daarnaast werd de problematiek ook in de publiekrechtelijke SER en de privaatrechtelijke Stichting van de Arbeid gearticuleerd. Articulatie van de thematiek kreeg vorm doordat sociale partners met elkaar en met het kabinet buiten de officiële 'verticale' lijnen in overleg traden. De Nederlandse rechter heeft zich bij zijn uitspraken in deze kwestie mede laten inspireren door het Europees Sociaal Handvest (ESH) dat het recht op het voeren van collectieve actie erkent.

Niet de verticale politiek, maar de rechter heeft uiteindelijk inhoud gegeven aan het stakingsrecht. De rechter functioneerde daarbij - net als in de euthanasiekwestie - echter niet in een maatschappelijk vacuüm. Zo werd de rechter naar 
aanleiding van de kritiek van de FNV op de Douwe Egberts-zaak terechtgewezen door het Comité van onafhankelijke deskundigen, een orgaan van het ESH dat toeziet op een juiste rechtstoepassing in de afzonderlijke lidstaten. De genoemde rechterlijke uitspraak bleek niet in overeenstemming te zijn met het ESH (Batenburg 2005). Er kan wat dit betreft van een leerproces gesproken worden, waarbij gaandeweg juridische en maatschappelijke ervaring is opgebouwd. Door te 'experimenteren' kon het recht voor de Nederlandse situatie stap voor stap verder worden omlijnd.

Vanuit de verticale traditie bezien heeft de politiek in deze kwestie gefaald. Een wettelijke regeling is tot op heden uitgebleven. Recentelijk heeft de regering nog eens bevestigd niet voornemens te zijn te voorzien in een algemene regeling van het stakingsrecht. "De jurisprudentie die zich op het gebied van het stakingsrecht heeft ontwikkeld, is een adequaat substituut gebleken, waarbij - meer dan voor de wetgever mogelijk zou zijn - rekening kon worden gehouden met bijzondere omstandigheden die aan elke collectieve actie eigen zijn" (TK 29 941, nr. 6, 8). Dat is een opmerkelijke uitspraak. Hierin erkent de regering, een vanuit de verticale traditie bezien centrale politieke actor, immers de belangrijke, zo niet onmisbare, rol die de horizontale traditie in de Nederlandse politiek kan spelen.

\subsubsection{HET AKKOORD VAN WASSENAAR}

Als derde voorbeeld kan de geschiedenis rond het Akkoord van Wassenaar dienen. Daarin komt niet alleen de creatieve rol naar voren die politiek vanuit de horizontale traditie kan spelen, maar treden ook de beperkingen van deze vorm van politiek aan het licht.

In de jaren zestig werd het draagvlak van de overlegeconomie tussen werkgevers, werknemers en de overheid, zoals die institutioneel vorm had gekregen in de Stichting van de Arbeid en de SER, gaandeweg uitgehold. De betrokken maatschappelijke organisaties ontwikkelden zich tot professionele belangenbehartigers en het delen van de publieke ruimte kwam in een kwaad daglicht te staan. De keerzijde van beleidsvervlechting werd duidelijk: gevestigde belangenorganisaties maakten gebruik van hun feitelijke 'vetopositie' en ontwikkelden hindermacht. De vereiste noodzaak tot consensusvorming in de vaste podia van overleg en advies ontaardde in traagheid en geblokkeerde besluitvorming (Scharpf 1988). Partijen schoven elkaar de zwartepiet toe: vakbondsvertegenwoordigers beschuldigden werkgevers van een vertrouwensbreuk, werkgevers betwistten de tegenpartij hun plaats aan de onderhandelingstafel, en beiden richtten zich tegen de politiek.

Het telkens weer mislukken van het centrale overleg resulteerde begin jaren zeventig in een fiks aantal looningrepen door de overheid, waardoor het overlegklimaat verder ondermijnd raakte. Toen in de tweede helft van de jaren zeventig actief keynesiaans begrotingsbeleid bovendien geleidelijk aan plaatsmaakte voor een stringenter macro-economisch beleid gestoeld op monetaire inzichten, 
verschoof daarmee de verantwoordelijkheid voor werkgelegenheid naar aanpalende beleidsdomeinen. Dat had ingrijpende gevolgen voor de loonpolitiek en de arbeidsvoorwaardenvorming. Het uitblijven van vrijwillige matiging resulteerde in een stijging van de arbeidsinkomensquote en erosie van de rendementspositie van het Nederlandse bedrijfsleven.

Aan het begin van de jaren tachtig groeide de overtuiging dat een krachtige bijstelling van het beleid onvermijdelijk was. De explosieve groei van de werkloosheid, die rond 1980 met tienduizend personen per maand opliep, samen met het hoge financieringstekort en de verslechterde positie van de Nederlandse bedrijven, bracht een sense of urgency teweeg. Het 'puzzelen' van voorgaande jaren, de teleurstelling over het bijna gesloten centrale akkoord in 1979, verschillende rapporten en de commissie-Wagner hadden al een omslag in het denken opgeleverd. Wat nog ontbrak was het poweren van een nieuwe politieke coalitie om de bestaande institutionele impasse te doorbreken. Het macro-economisch beleid van het 'no-nonsense' kabinet-Lubbers dat na de verkiezingen van 1982 aantrad, verlegde de prioriteit naar het herstel van de rendementspositie van het bedrijfsleven door middel van het terugdringen van de collectieve sector. Met de aangekondigde opschorting van de koppelings- en indexeringssystematiek tussen lonen, ambtenarensalarissen en uitkeringen, herwon het kabinet discretionaire ruimte in het eigen budgettaire beleid.

Onder de dreiging van een nieuwe looningreep sloten werkgevers- en werknemersorganisaties op 24 november 1982 in de Stichting van de Arbeid een overeenkomst getiteld Centrale aanbevelingen inzake aspecten van een werkgelegenheidsbeleid. Die overeenkomst zou later het Akkoord van Wassenaar gaan heten. $\mathrm{Na}$ een decennium van institutionele besluiteloosheid, vonden werkgevers en werknemers elkaar in een ruilpakket van marktconforme loonmatiging en arbeidsduurverkorting ter versterking van de rendementen van het bedrijfsleven en ter leniging van de werkloosheid. Er was een 'horizontaal-politieke' oplossing gevonden, zij het onder de dreiging van ingrijpen door de 'verticale' politiek. Door 'winst en werk boven inkomen' te stellen, doorbrak het Akkoord van Wassenaar twee taboes: aan werknemerskant het recht van de prijscompensatie en aan werkgeverskant de herverdeling van werk. Ook maakte het Akkoord de weg vrij voor bipartiete samenwerking en zelfregulering, waarmee het primaat van de Nederlandse arbeidsverhoudingen werd verplaatst van de nationale politieke arena naar het sectorale niveau (Van den Toren 1996). Het Akkoord van Wassenaar leidde zo niet alleen tot specifieke institutionele arrangementen waarin de arbeidsverhoudingen vorm konden krijgen. Er ging ook een belangrijke morele kracht van uit. De bereidheid om de lonen te matigen bleef hoog, ook toen de werkgelegenheid en de bedrijfsrendementen jaren achtereen gestaag bleven groeien. Het Stichtingsakkoord van 1982 werd dan ook tot ver in de jaren negentig gevolgd door een reeks soortgelijke akkoorden.

Aan het einde van de jaren tachtig was er tijdens de WAO-crisis nogmaals sprake van collectieve besluiteloosheid. De commissie-Buurmeijer (1993) concludeerde 
later dat de sociale partners en de overheid elkaar in een "verlammende greep" hadden gehouden. Vanaf het midden van de jaren negentig werd daarom gekozen voor herstel van het politieke primaat. In toenemende mate werden bestuurlijke problemen toegeschreven aan de onduidelijke verantwoordelijkheids- en bevoegdheidstoedeling in verschillende beleidsdomeinen. Door het eenzijdige ingrijpen van de overheid in de sfeer van de sociale zekerheid is aanzienlijke efficiëntiewinst geboekt. Zonder de hieraan voorafgaande langetermijnstrategie van georganiseerde loonmatiging van dezelfde sociale partners die zich binnen de sociale zekerheid zo hadden misdragen, waren aanpassingen in de verzorgingsstaat echter waarschijnlijk een stuk moeilijker geweest. De belofte van 'werk, werk, en nog eens werk' van het paarse kabinet was een voorwaarde voor hervormingen in de sociale zekerheid. De basis voor de miraculeuze werkgelegenheidsgroei in Nederland was echter in het Akkoord van Wassenaar uit 1982 gelegd (Visser en Hemerijck 1998).

De les van de commissie-Buurmeijer werd het dominante besturingsparadigma onder de paarse kabinetten. Daarmee kwam in het economische beleid de verticale traditie voorop te staan. Maar ook in tal van andere sectoren werden maatschappelijke organisaties en adviesinstellingen geweerd uit de fora van beleidsadvisering, -voorbereiding en -uitvoering. Het op nationaal niveau georganiseerde horizontale beleidsbestel werd opengebroken. Met het scheiden van overleg en advies is echter ook veel inhoudelijke beleidskennis en deskundigheid van intermediaire organisaties verloren gegaan. Het gevolg is een gebrekkige aansluiting met de uitvoeringspraktijk en meer regeldruk en overheidstoezicht en -controle (WRR 2004). Na de commissie-Buurmeijer is de aandacht meer komen te liggen op het afleggen van verantwoording en controle aan de overheid, en minder op de inhoudelijke betrokkenheid van maatschappelijke organisaties bij het oplossen van hardnekkige problemen.

\subsubsection{VOORBEREIDING OP DE INVOERING VAN DE VREEMDELINGENWET 2000}

De voorbereiding op de invoering van de Vreemdelingenwet in de periode 19981999 is het laatste voorbeeld dat wij zullen behandelen van de wijze waarop een proces van wetgevingsvoorbereiding in samenspraak met belanghebbende partijen tot stand kan komen. Interessant aan dit voorbeeld is de doelbewuste inzet van een combinatie van verticale en horizontale praktijken en de relatief korte tijd waarin het wetsvoorstel tot stand kwam. Meer dan in de andere voorbeelden is hierbij ook de invloed van het lokale bestuur aan de orde. Lokale bestuurders zijn bij de voorbereiding niet alleen aangesproken als toekomstige mede-uitvoerders van de Vreemdelingenwet, maar vooral ook als 'ervaringsdeskundigen' met een eigen expertise en met een eigen verantwoordelijkheid in het zorgvuldig omgaan met degenen die onder de Vreemdelingenwet vallen.

De herziening van de Vreemdelingenwet werd in juli 1998 door het tweede kabinet-Kok aangekondigd. Ter voorbereiding op deze herziening werd een projectteam samengesteld bestaande uit vertegenwoordigers van de betrokken directies 
van het ministerie van Justitie en de Immigratie en Naturalisatie Dienst (IND). De leiding van de projectgroep was in handen van een externe projectleider. De keuze van een externe projectleider was niet gebruikelijk en, zowel bij leden van het parlement als bij het ministerie zelf, omstreden. De vraag was of een zo belangrijk proces van wetgeving wel aan een buitenstaander kon worden uitbesteed. De keuze van de toenmalige staatssecretaris (Job Cohen) voor een extern projectleider had echter juist te maken met de aanwezigheid van veel verschillende belangen, de complexiteit van de materie en de wens om vooraf maatschappelijk draagvlak te krijgen voor de nieuwe wet.

Het projectteam had als taak de ontwikkeling van een wetsvoorstel, de bijbehorende uitvoeringswet en de lagere regelgeving. Bovendien was het de taak van de projectgroep om de implementatie van de nieuwe regels in het veld voor te bereiden. Van meet af aan werd bepaald dat het team zoveel mogelijk organisaties diende te betrekken bij de totstandkoming van de wet en de lagere regelgeving (Gerritsen et al. 2001). Dit gebeurde in de praktijk door middel van verschillende brainstormsessies met deskundigen en gesprekken met alle betrokken organisaties aan het begin van het wetgevingsproces. Zoals blijkt uit het projectplan en uit informatie van direct betrokkenen was het oogmerk van deze aanpak tweeledig: zo goed mogelijk gebruik maken van de kennis en ervaring van betrokkenen, opdat er een betere en beter werkbare wet tot stand zou komen en het verkrijgen van een zo breed mogelijke acceptatie van de wetswijziging.

Niet alleen bij aanvang van het werk van het projectteam, maar ook na vaststelling van het eerste wetsontwerp is gebruik gemaakt van de kennis en ervaring van betrokken organisaties. Nadat het eerste wetsontwerp in het voorjaar 1999 in de ministerraad werd vastgesteld en voor advies naar de Raad van State gestuurd, werd het voorstel ook voorgelegd aan instanties die in de toekomst met de wet in aanraking zouden komen. Omdat de uitvoering van de wet door gemeenten ter hand genomen diende te worden, werd in deze fase meer in het bijzonder ook aandacht besteed aan het de rol en positie van het lokaal bestuur. In samenspraak met het lokaal bestuur werd gekeken naar de uitgangspunten van het wetsontwerp en naar de gevolgen ervan voor de feitelijke uitvoering.

Met deze werkwijze is een unieke combinatie gerealiseerd. Door te kiezen voor een aparte projectstructuur werd het mogelijk de verticale aanpak van het wetgevingsproces te combineren met meer horizontale elementen. Dit gebeurde door actoren te mobiliseren en in te schakelen die op grond van deskundigheid en ervaring een bijdrage konden leveren aan de oplossing van een ingewikkeld en omstreden maatschappelijk vraagstuk. Interessant van dit voorbeeld is bovendien de wijze waarop met het proces van meningsvorming en beïnvloeding door partijen is omgegaan. Hoewel het projectteam op de hoogte was van de standpunten van alle betrokkenen, zijn ze niet allemaal ook gehonoreerd. Toch had de gekozen aanpak aanzienlijke voordelen. De gevolgde werkwijze heeft "niet altijd geleid tot acceptatie maar wel bijgedragen aan begrip voor gemaakte keuzes" (Gerritsen et al. 2001: 11). Het projectteam heeft zelf een proces van afweging en 
beoordeling georganiseerd. De uiteindelijke beslissing werd genomen door de verantwoordelijke bewindspersonen. Deze werkwijze bleek ook door de Tweede Kamer gesteund te worden. De vaste commissie voor Justitie organiseerde, net als het projectteam, rondetafelbijeenkomsten met de betrokkenen, waaronder uitvoeringsorganisaties, het lokaal bestuur, rechtbanken en belangenorganisaties van vluchtelingen, en ging met deze groepen in gesprek over de voor- en nadelen van het voorliggende wetsvoorstel.

Het projectteam was niet alleen belast met de ontwikkeling van het wetsvoorstel, maar ook met de uitvoeringswet en de implementatie. Dit werd van groot belang geacht, omdat uit de evaluatie van de Vreemdelingenwet van 1994 bleek dat er sprake was van allerlei uitvoeringsproblemen. Door de verschillende belanghebbenden opnieuw bij dit onderdeel van het werk te betrekken, is een aantal condities geformuleerd die gerealiseerd moesten zijn bij de invoering van de nieuwe wet. Het projectteam is op verschillende tijdstippen nagegaan in hoeverre deze condities in het veld waren vervuld.

Inmiddels is de nieuwe Vreemdelingenwet geëvalueerd (Commissie Evaluatie Vreemdelingenwet 2006). Hoewel de gevolgde procedure bij de ontwikkeling van de wet bijdroeg aan begrip voor de gemaakte keuzes, lijkt de maatschappelijke acceptatie van het beleid te zijn afgenomen. Voor een deel is dit waarschijnlijk te wijten aan externe omstandigheden. De daling van het aantal asielaanvragen en verharding van het politieke klimaat zijn mede van invloed op de feitelijke beoordeling van het functioneren van de huidige wet. Een van de belangrijke aspecten die daarbij waarschijnlijk een rol heeft gespeeld is de wijze waarop met afgewezen asielzoekers zou moeten worden omgegaan.

\subsubsection{INTELLIGENTE COMBINATIES}

Resumerend kunnen we vaststellen dat in elk van de in het voorgaande behandelde voorbeelden sprake is geweest van een combinatie van horizontale en verticale politieke praktijken. In veel gevallen voltrok de horizontale praktijk zich voor een belangrijk deel buiten de kaders en instellingen die de verticale traditie voor legitieme politiek aanwijst. Daarbij heeft steeds het probleem dat aan de orde was vooropgestaan. Door de tijd te nemen, door ervaringen te articuleren en te verzamelen en overleg te voeren, werd gaandeweg duidelijk wat er aan de hand was. Vervolgens kon worden vastgesteld van wie, waarover, wat voor soort beslissing mocht worden verwacht. Er kan daarbij van een zoektocht gesproken worden waarin de kaders ontdekt moesten worden waarbinnen over een kwestie beslist zou kunnen worden. Binnen dit maatschappelijke leerproces wordt kennis verworven, ontstaat inzicht in de normatieve aspecten van het probleem en komen bestuurlijke middelen beschikbaar die het mogelijk maken de zaken beter aan te pakken dan voorheen.

De verhouding tussen verticale en horizontale politieke praktijk is er dus niet bij voorbaat een waarin de laatste door de eerste wordt gecontroleerd. Dat kán het 
geval zijn, zoals bij het zelfbestuur van universiteiten dat zich afspeelt op terreinen en binnen grenzen die door de wetgever uitdrukkelijk zijn vastgelegd. In andere gevallen, vooral bij problemen waarover nog weinig bekend is, lijkt een andere beschrijving meer adequaat, namelijk die waarin de rol van de verticale politieke praktijk een voortzetting van horizontale politiek vormt op bijzondere plaatsen en met bijzondere middelen. Horizontale politiek hoeft immers niet bij de deur van de Tweede Kamer stil te houden. Als zulke politiek daar arriveert, kan echter van (wetgevende en controlerende) middelen gebruik worden gemaakt die niet op andere plaatsen beschikbaar zijn. Er kan in een ander register worden gesproken, van bestuurlijke technieken (zoals wetgeving) gebruik worden gemaakt die elders niet beschikbaar zijn. Vanuit de horizontale traditie bezien vormen regeringsbesluiten en parlementaire behandeling dus een bijzondere fase van een proces dat eerder door anderen, op andere plaatsen en met andere middelen, is begonnen en dat mogelijk daarna ook weer elders zal worden voortgezet.

De voorbeelden illustreren dat. In het geval van de euthanasieproblematiek vond de horizontale politiek niet plaats onder toezicht van regering en parlement. Zij vond plaats in de rechtszaal, in publieke discussies en in vaktijdschriften. Toen de discussies zich uiteindelijk van de rechtszaal naar het parlement verplaatsten, vormde de parlementaire behandeling het sluitstuk van de ontwikkeling van horizontale politiek. Toen de euthanasiekwestie op die plaats was aangeland, kon van een belangrijk nieuw middel gebruik worden gemaakt: de eerder opgebouwde, inhoudelijk gestuurde oordeelsvorming die tot dusverre in jurisprudentie was neergeslagen, kon in het parlement in wetgeving worden vastgelegd.

Ook in het geval van de ontwikkeling van het stakingsrecht kan niet gesproken worden van onderschikking van de horizontale politiek aan de verticale instellingen. In dit geval heeft, zoals ter sprake is geweest, de regering er recent zelfs nog eens expliciet van afgezien zich het probleem toe te eigenen en is ervoor gekozen de weg van de jurisprudentie te blijven volgen. Die zou naar het oordeel van de regering een adequaat substituut voor wetgeving zijn, waarbij - meer dan voor de wetgever mogelijk zou zijn - rekening kan worden gehouden met bijzondere omstandigheden.

Rond het Akkoord van Wassenaar zijn de verhoudingen gecompliceerder. Het lijdt geen twijfel dat het Akkoord mede tot stand is gekomen onder de dreiging van ingrijpen door het kabinet. De inhoud van het Akkoord kan echter niet door die dreiging worden verklaard, noch zijn daaruit volgende werking: die zijn het resultaat van discussies en onderhandelingen tussen sociale partners, buiten de directe bemoeienis van de regering om.

In het geval van de Vreemdelingenwet 2000 is gekozen voor een 'buitenboordmotor' aan het departement teneinde voldoende kennis en ervaring te kunnen mobiliseren. De verantwoordelijke staatssecretaris heeft daarin een belangrijke rol gespeeld door een deel van het werk buiten het departement en buiten de 
politiek te laten plaatsvinden met uiteraard voldoende terugkoppelingsmechanismen. Aldus ontstond er ruimte om een wetgevingsproces in gang te zetten dat voldoende rekening hield met de praktijk en de feitelijke uitvoering. In dit opzicht is de voorbereiding van de nieuwe Vreemdelingenwet een goed voorbeeld van een productieve vervlechting van beleid met uitvoering.

In een complexe samenleving heeft de overheid, zoals in hoofdstuk 2 al is opgemerkt, uiteenlopende rollen te vervullen. Daarmee is echter nog niet gezegd hoe die rollen moeten worden geconceptualiseerd en hoe de onderlinge verhoudingen moeten worden gezien. De behandelde voorbeelden brengen naar voren dat er verschillende verhoudingen mogelijk zijn. Soms vindt horizontale politiek plaats binnen kaders die in de verticale politiek zijn vastgelegd. Dan staat het 'primaat van de (verticale) politiek' voorop. In andere gevallen heeft de horizontale traditie echter een eigenstandige plaats naast de verticale of legt zij de basis voor latere verticale politiek. In sommige gevallen kan de verticale politiek om inhoudelijke redenen ook beslissen zich afzijdig te houden. Zo heeft de regering in het geval van het stakingsrecht na zich enige tijd als speler te hebben gemanifesteerd besloten zich niet als regisseur op te werpen, maar toeschouwer te worden.

De vraag welke rollen de overheid heeft te spelen vormt voor de horizontale en de verticale traditie dus een verschillende uitdaging. Vanuit de verticale traditie bezien brengt de verscheidenheid van rollen die de overheid speelt in de eerste plaats een lastig legitimatieprobleem voort. Hoe kan gegarandeerd worden dat, waar de overheid zich naast anderen als speler op het politieke toneel manifesteert, het primaat van de politiek niet in gevaar komt? Hoe kan voorkomen worden dat, als de overheid met tal van andere maatschappelijke actoren in zee gaat om een oplossing te vinden voor maatschappelijke problemen, de democratische legitimiteit van overheidsbeslissingen erodeert?

Vanuit de horizontale traditie bezien dienen zich andere vragen aan. Hoe moeten horizontale bestuurlijke processen vormgegeven worden als het streven is de beraadslagingen te laten uitmonden in overleg tussen regering en parlement? Door wie kan dat bestuurlijke proces worden gedragen, in welke gremia kan het zich ontplooien? De voorbeelden laten zien dat het antwoord hierop niet eensluidend is. De rechtszaal, geformaliseerd overleg, informeel overleg tussen belangengroepen, de wisselwerking tussen officiële adviesorganen en uiteenlopende professionele gremia, individuele onderzoekers en politici, en brainstormsessies en groepsgesprekken zijn reeds ter sprake geweest. Dat geeft al aan dat er vele mogelijkheden zijn. In het ene geval kan het verstandig zijn om bij het definiëren van problemen vanuit burgers en bedrijven te rederenen en in het andere geval om gespecialiseerde deskundigen te raadplegen of experimenten op te zetten. Bij sommige kwesties zullen overleggen met milieuorganisaties en ambtenaren een dergelijke rol kunnen vervullen. Niet elke plek, wijze van onderzoek en vorm van samenwerking is geschikt om bruikbare oplossingen voor problemen te formuleren. In paragraaf 4.3 zal daarom nader ingegaan worden op de vraag hoe 
zulke uiteenlopende vormen van politieke interactie leereffecten kunnen bewerkstelligen.

Ook de relatie tussen horizontale en verticale politiek roept de nodige vragen op. Wanneer moet tussen beide geschakeld worden? Op welk moment moet het bespreken van de kernvragen omtrent beleid - werkt het, past het, mag het en hoort het? - dat zich op tal van plaatsen heeft afgespeeld naar de Tweede Kamer worden verplaatst, zodat het overleg daar in de vorm van wetgeving kan worden afgesloten? Hoe kan verzekerd worden dat de inhoudelijke rijkdom van de horizontale beraadslagingen bij dit transport naar de instellingen van de verticale politiek niet in procedurele kwesties weer teloorgaat? Of omgekeerd, wanneer moet de verticale politiek afzien van de voor parlement en regering beschikbare middelen en het politieke proces - binnen wettelijke kaders, of zonder uitdrukkelijk geformuleerde wettelijke kaders - aan bestuurders buiten de keten van delegatie en verantwoording overlaten? Afhankelijk van het probleem moet steeds een inhoudelijke afweging worden gemaakt. Dat is natuurlijk een waarheid als een koe. In het denken over politiek is dit ogenschijnlijk triviale gegeven echter op de achtergrond geraakt. In het huidige politieke klimaat overheersen de verticale, hiërarchische reflexen.

\subsection{VERANDERENDE ROLLEN VAN AMBTENAREN}

De verhouding tussen de horizontale en verticale politiek heeft niet alleen gevolgen voor politici en andere bestuurders, maar ook voor ambtenaren. Ook voor hen is de feitelijke situatie waarin zij moeten opereren gecompliceerder dan het door de verticale traditie gedomineerde denken over overheid en politiek veronderstelt. Ministers en hoge ambtenaren zien hun onderlinge verhoudingen dan ook al lang niet meer uitsluitend in weberiaanse termen (Jeliazkova en Hoppe 1996; 't Hart en Wille 2006; 't Hart et al. 2002). Naast de klassieke rol als ondergeschikt deskundige en uitvoerder van beleid worden ook diverse andere rollen onderscheiden. Voor de discussie kunnen we ons beperken tot de rollen van de procesmanager en de professionele ambtenaar. Deze rollen zijn in de loop der tijd naast elkaar ontstaan. Het gevolg is dat over de rol en positie van de moderne ambtenaar de nodige onduidelijkheden bestaan. Ambtenaren worden zowel aangesproken op hun weberiaanse taakopvatting als op processturing en politieke gevoeligheid. $\mathrm{Zij}$ moeten daarbij aan verwachtingen voldoen die niet altijd sporen.

\subsubsection{PROCESMANAGER EN PROFESSIONELE AMBTENAAR}

Beperken we ons tot de hogere echelons van het ambtelijke apparaat, dan vormt de procesmanager de belichaming van het besturingsparadigma van het New Public Management. Zijn rol is nog volledig binnen de verticale traditie te formuleren, zij het dat daarbij de nadruk meer op de bestuurlijke processen dan op de uitvoering van regels wordt gelegd. In die verschuiving kan een erkenning gezien worden van het feit dat bestuurlijke processen complexer zijn dan in Webers theorie is verondersteld. Anders dan bij de klassieke ambtenaar is het uitgangs- 
punt hier niet zozeer specifieke dossierkennis, regelgebondenheid en hiërarchie, alswel het boeken van voortgang en het organiseren van een effectief en efficiënt besluitvormingsproces met inachtneming van de procedurele vereisten. De procesmanager heeft vooral de opdracht om tot een goede fasering in de tijd te komen, en op het juiste moment zaken die voor het politieke optreden van de minister van belang zijn te agenderen. Het procesmanagement kan ook het leggen van verbindingen met andere departementen en eventuele partijen buiten de overheidsorganisatie vereisen, teneinde het proces op gang te houden en te zorgen dat op het juiste moment de juiste mensen bij elkaar worden gebracht. Het leggen van zulke contacten is er echter op gericht de processen binnen het overheidsapparaat te verbeteren en de besluitvorming in de verticale politieke lijn soepel te laten verlopen. De verhouding tussen politiek en ambtelijk apparaat wordt door de intrede van de procesmanager niet in het geding gebracht.

Terwijl de procesmanager vooral bezig is met het sturen van beleid, gaat het bij de professionele ambtenaar om het sturen met beleid. Mertens (1996) spreekt over 'beleidsadviseurs in vaste dienst'. Kenmerkend voor de rol van de professionele ambtenaren is dat zij door te adviseren met kennis van zaken en vanuit een eigen positie inhoudelijk bijdragen aan het proces van beleids- en besluitvorming. De professionele ambtenaar wordt daarbij geacht niet zijn eigen voorkeuren te laten spreken. Hij dient daarentegen een goed oog te hebben voor wat in de samenleving leeft. Politieke vraagstellingen zijn waardegebonden en daardoor sterk onderhevig aan wisselende preferenties. Het vermogen dit op het spoor te komen en te doorgronden is een belangrijk onderdeel van het vakmanschap van de professionele ambtenaar. Professionaliteit vraagt om systematische reflectie en dus ook om een zekere distantie. Zij eist vaak ook een wijdere tijdshorizon dan de vierjarige cyclus die het politieke leven beheerst. Het onderkennen van het politieke karakter van elke vraagstelling is dus essentieel. Tegelijkertijd gaat het bij de professionele ambtenaar om het vermogen om andere probleemdefinities en oplossingen naar voren te brengen dan welke door de politieke ambtsdragers in eerste instantie worden gepresenteerd.

De professionele ambtenaar werkt vanuit het besef dat er voor elk maatschappelijk probleem meer dan één oplossing is en dat geen enkele oplossing ideaal is, omdat er altijd sprake is van een context van verschillende posities en belangen. Hij kent deze posities en belangen en weet ze te duiden. De professionele ambtenaar moet daarom over kennis van zaken beschikken, die bij voorkeur uit verschillende bronnen (actoren in het beleidsveld) afkomstig is. Dit laatste betekent dat de professionele ambtenaar zelf actief op zoek gaat naar kennis en informatie, niet alleen binnen zijn eigen organisatie maar juist ook daarbuiten. Daarbij volstaat vanzelfsprekend niet het raadplegen van de traditionele en doorgaans goed georganiseerde beleidspartners. Juist bij nieuwe en onzekere vraagstukken is het van belang om buiten de geïnstitutionaliseerde paden te treden, relevante publieken op te sporen en gegeven probleemrepresentaties kritisch te beschouwen. De professionele ambtenaar moet helpen ervaringen, oordelen en meningen te articuleren en die verzamelen. Idealiter is hij zowel een 'expert' die zich 
beroept op zijn eigen professionele analytische deskundigheid als een 'beleidsfilosoof' die het als zijn verantwoordelijkheid beschouwt de politieke leiding en zijn collega's bewust te maken van soms tegengestelde manieren van denken over beleidsproblemen en oplossingen (Jeliazkova en Hoppe 1996).

Feit is dat de professionele ambtenaar zijn intrede in het overheidsapparaat heeft gedaan. Als we de klassieke ambtenaar als het vertrekpunt beschouwen voor de rol van de ambtenaar, dan heeft er een uitwaaiering plaatsgevonden naar enerzijds een grotere betrokkenheid bij de inrichting van het besluitvormingsproces en anderzijds een grotere invloed op de inhoud van het besluitvormingsproces. Deze uitwaaiering van rollen doet zich vooral gelden onder bestuurlijke condities die gekarakteriseerd kunnen worden als grensvervaging, ambiguïteit in de probleemdefinitie en interpretaties van maatschappelijke kwesties die normatief zeer omstreden zijn (Noordegraaf 2004). Als gevolg hiervan zullen ambtenaren eerder zelfstandig kennis moeten opdoen en polsen wat de slaagkans is van nieuw beleid door antwoorden op de vier beleidsvragen te formuleren. Hun werk veronderstelt aan de ene kant puzzling: het zoeken naar passende oplossingen voor problemen, en aan de andere kant gaat het om powering: het sluiten van politieke deals en verwerven van voldoende politieke steun voor oplossingen (Heclo 1974). In het door het verticale denken gedomineerde beeld van de verhoudingen van politiek en ambtelijk apparaat is voor deze meer zelfstandige rol echter geen plaats.

De rol van de professionele ambtenaar overschrijdt de grenzen die de verticale traditie stelt, en dat heeft uiteraard gevolgen voor de aard van de politiek-ambtelijke verhoudingen en voor de verhoudingen van ambtenaren met maatschappelijke actoren die in het publieke domein actief zijn. Denk bijvoorbeeld aan het beginsel van de ministeriële verantwoordelijkheid. De minister is verantwoordelijk voor alles wat er binnen het gebied van zijn portefeuille wordt gedaan en nagelaten. Het parlement kan de minister naar huis sturen op het moment dat het niet langer overtuigd is van diens vermogen om op zijn terrein politiek leiding te geven. Om hier goed mee om te kunnen gaan en de risico's klein te houden, dient er door de minister daadwerkelijk leiding te worden gegeven en sprake te zijn van beïnvloeding van het ambtelijke apparaat. De politieke gezagsdrager treedt dus op als principaal/opdrachtgever (politiek primaat), het ambtelijk apparaat adviseert desgevraagd en voert als agent/opdrachtnemer zo goed mogelijk uit (ambtelijke loyaliteit). De politiek verantwoordelijken moeten ervan uit kunnen gaan dat de ambtenaren hun taken professioneel nauwgezet en binnen de regels van de wet uitvoeren, maar dat ook doen conform zijn politieke opvattingen. Dit laatste geldt des te meer als ambtenaren het niet eens zijn met de bewindspersoon.

\subsubsection{VERANDERENDE VERHOUDINGEN}

Naarmate de rol van de ambtenaar professioneler en dus politieker wordt, verandert zijn rol van ondergeschikte (agent) in die van nevengeschikt aan de politieke 
leiding. Hij is niet alleen uitvoerder van beleid maar ook coproducent ervan. Daar komt bij dat de afhankelijkheid van de politieke leiders van het ambtelijk apparaat enorm is toegenomen (Van Thijn en Cardoso Ribeiro 2004). Tegenover het beeld van de 'almachtige' politieke leider en de 'uitvoerende, ondergeschikte' ambtenaar moet het beeld worden geplaatst van politici als lekenbestuurders tegenover een omvangrijk, complex en deskundig ambtenarenapparaat (Van Gunsteren 1994). Hun afhankelijkheid van deze deskundigheid is groot.

De relaties met andere actoren veranderen ook. Er is meer actief verkeer en beïnvloeding. De kennis en opvattingen die daarbij worden opgedaan, worden ingebracht in de politiek-ambtelijke relatie met als gevolg dat die relatie diffuser wordt. Naast de klassieke democratische kanalen worden kennis, belangen en maatschappelijke ervaringen nu ook via de ambtelijke lijn in het politieke besluitvormingsproces ingebracht. Deze vorm van beïnvloeding van zowel de probleemdefinitie als de mogelijke oplossing is minder zichtbaar en controleerbaar, maar wint wel aan belang en gewicht.

Hoewel de betrokken ambtenaren en politieke ambtsdragers beseffen dat het weberiaanse model niet meer voldoet ('t Hart et al. 2002), handhaven ze niettemin de klassieke verhouding en rolopvatting van de ambtenaar als normatief ijkpunt (zie ook hoofdstuk 3). De nieuwe rollen van de ambtenaar worden als een aanvulling op het klassieke model gezien, waarna wordt opgemerkt dat het relatief zelfstandig opereren van ambtenaren het beginsel van de neutraliteit zou kunnen ondermijnen en politieke controle op hun handelen in de weg staat. De klassieke visie op de posities van politici en ambtenaren blijft vooropstaan. De feitelijke complementariteit die empirisch kan worden vastgesteld, wordt geacht vorm te krijgen binnen een hiërarchisch gedefinieerde relatie waarbij uiteindelijk de politieke dominantie centraal staat.

Diezelfde houding kleurt het denken over de verhouding tussen ambtenaren en het parlement. Dat parlement moet de regering controleren. Op dit moment krijgt het formeel zijn informatie via de bewindspersonen: zij vormen het kanaal waarlangs informatie dient te stromen. Dit is expliciet vastgelegd in de Aanwijzingen inzake externe contacten van rijksambtenaren die in 1998 door het kabinet-Kok zijn geformuleerd. De Aanwijzingen zijn ingegeven door verticaal denken over politiek en hadden als oogmerk het onderscheid tussen de ministeriele verantwoordelijkheid versus de ambtelijke verantwoordelijkheid nadrukkelijker te markeren. Overigens zijn deze aanwijzingen door velen begrepen als een beperking voor ambtenaren: in principe worden er geen directe contacten tussen parlementariërs en ambtenaren onderhouden. Ze beogen een halt toe te roepen aan een sluipend ontstane horizontale praktijk. Niessen (2003) geeft aan dat hiervan in de praktijk niet veel sprake van is geweest maar de beeldvorming over de relatie politici-ambtenaren is er wel door bepaald. De richtlijn is synoniem geworden voor de beperking van het onderling contact (Bureau Algemene Bestuursdienst 2006). Deze aanwijzingen hebben daarom ook onbedoelde negatieve bijeffecten. Tweede Kamerleden hebben een beperkte ondersteuning voor 
hun werk. Zij moeten hun aandacht over een groot aantal dossiers verdelen, zeker als zij deel uitmaken van een relatief kleine fractie. Als het raadplegen van ambtenaren over een zaak omstreden is, staan hen slechts twee wegen open om toch de informatie te krijgen die voor hun controlerende taak noodzakelijk is: zij kunnen Kamervragen stellen, of hun informatie ontlenen aan burgers, belangengroepen en uiteraard de media. Het gevolg is incidentenpolitiek: geruchten en mediaberichten leiden tot Kamervragen, omdat er geen andere manier is om de informatie te verifiëren.

Dat leidt op zijn beurt tot verdere negatieve gevolgen, zoals cynisme en een negatieve beoordeling van wederzijdse kwaliteiten. Ambtenaren worden ertoe verleid Tweede Kamerleden niet serieus te nemen. De vele Kamervragen kunnen bij deskundige ambtenaren de indruk wekken dat parlementariërs de klok hebben horen luiden, maar niet weten waar de klepel hangt. Dat maakt het moeilijk het parlement op andere momenten als een inspiratiebron voor de ontwikkeling en uitvoering van beleid te waarderen. Op hun beurt worden parlementariërs ertoe gebracht departementen te gaan zien als instellingen die er in de eerste plaats op uit zijn zaken 'onder de pet' te houden. Het leidt bovendien tot een bevestiging van de afrekencultuur: als er dingen fout gaan, gaan parlementariërs met de wijsheid achteraf op zoek naar de schuldigen. Het bestuur vlucht in defensief gedrag ('t Hart en Wille 2006) en zo ontstaat een klimaat dat zich slechts moeizaam leent voor reflectie en het leren van fouten.

Voorstellen om via enkele nieuwe procedures parlementaire controle meer systematisch te organiseren bieden ondertussen weinig soelaas: de introductie van de verantwoordingsdag op de derde woensdag in mei en de oprichting van het onderzoeks- en verificatiebureau van de Tweede Kamer zijn maatregelen die de controle op het overheidsbeleid vergroten, maar als zodanig geheel binnen het verticale denken passen. De vrijwel exclusieve oriëntatie op de verticale traditie van denken leidt ertoe dat de feitelijke verhoudingen tussen politiek en ambtelijk apparaat onvoldoende serieus kunnen worden genomen. Bij het nadenken over voorstellen om die verhoudingen te verbeteren worden daardoor belangrijke kansen gemist. Het initiatief van de ABD om de dialoog tussen ambtenaren en politici weer op gang te brengen, vormt wellicht een kentering omdat daar juist de investering in de onderlinge verhoudingen wordt gewaardeerd (Bureau ABD 2006).

\subsection{EEN RIJK BESTUURLIJK ECOSYSTEEM}

Door het naast elkaar bestaan en door elkaar lopen van de verticale en de horizontale traditie biedt het Nederlandse politiek-bestuurlijke landschap een nogal onoverzichtelijke aanblik. In de grondwet en in het staatsrecht mogen de delegatie- en verantwoordingsrelaties helder vastliggen, de bestuurlijke praktijk is complexer, grilliger dan wat aan het papier is toevertrouwd. 


\subsubsection{ONOVERZICHTELIJK?}

De verleiding is uiteraard groot om te denken dat deze onoverzichtelijkheid de voornaamste bron vormt voor politiek falen en hardnekkige bestuurlijke problemen. Waar overzicht ontbreekt en de bestuurlijke verantwoordelijkheden niet helder zijn, kan immers niet adequaat worden gereageerd. Signalen van falen bereiken de politiek verantwoordelijken in zo'n situatie niet op tijd, gaan onderweg naar de verantwoordelijke top verloren, of arriveren daar - vervormd als hype - alleen via de media. De implementatie en uitvoering van besluiten is niet minder modderig. Wat aan de top besloten is, wordt in eindeloze overleggen in en tussen uitvoeringsinstanties aangelengd en niet conform de intenties uitgevoerd. Bestuurlijk onvermogen is het resultaat. De Maistre's uitspraak “ C'est l'opinion qui perd les batailles, et c'est l'opinion qui les gagne" indachtig rest de politicus dan nog slechts aandacht te besteden aan de beeldvorming. Wie indruk wil maken hoeft slechts het beeld dat nagelaten wordt naar zijn hand zetten. Waar onoverzichtelijkheid heerst en serieus besturen feitelijk onmogelijk is, moeten spindoctors de schijn ophouden.

Wie zich niet bij cynisme wil neerleggen lijkt slechts één weg te kunnen gaan: hij moet de complexiteit van de politiek-bestuurlijke verhoudingen te lijf, overzicht creëren en helderheid scheppen. Om de betrouwbaarheid en slagvaardigheid van politiek en overheid te verbeteren is dan leiderschap nodig, heldere verantwoordingslijnen, eenvoudiger en transparanter bestuurlijke structuren. Het primaat van de politiek moet herbevestigd worden, het aantal departementen gereduceerd, en er moet worden gekapt in het woud van adviesorganen en intermediaire organisaties. Alleen zo zou er een directere terugkoppeling tussen uitvoering, politiek en burgers gegarandeerd kunnen worden, kan falen eerder worden gesignaleerd, sneller worden afgestraft en beter worden gecorrigeerd. Waar deze middelen geen soelaas brengen, omdat de taken waarvoor de overheid staat feitelijk te complex zijn om langs hiërarchische, bureaucratische lijnen te worden gecoördineerd, is het beter overheidstaken naar de markt over te hevelen. De economische theorie leert immers dat marktwerking wél tot snelle aanpassingen leidt. Privatisering vormt in dit opzicht een alternatief voor bestuurlijk leiderschap en transparantie. Zij levert bovendien het voordeel dat het beslag op de rijksbegroting - zij het niet noodzakelijkerwijs het beslag op de huishoudportemonnee van de burger - wordt beperkt.

Deze reactie op bestuurlijke problemen kan zoals in voorgaande hoofdstukken reeds is gesteld op een grote aanhang rekenen. Een lange reeks van hervormingsvoorstellen is er bovendien door geïnspireerd. Het politieke discours in Nederland in het afgelopen decennium is er door getoonzet. Het aantal hervormingsvoorstellen in deze lijn dat het werkelijk gehaald heeft en het beoogde effect heeft gesorteerd is echter gering. Dat kan gemakkelijk geïnterpreteerd worden als een nieuw bewijs van de stroperigheid van de Nederlandse verhoudingen, zo niet als teken dat de betrokkenen meer belang aan behoud van verworven posities hechten dan aan een goed werkende overheid. 
Klopt die redenering echter wel? Daarover is gerede twijfel mogelijk. Beschouw bijvoorbeeld het ontstaan van de rol van de 'professionele ambtenaar'. Dat deze rol zijn intrede heeft gedaan en hoge ambtenaren zich dus niet meer louter naar het klassieke weberiaanse rolmodel richten maar bestuurlijke taken op zich nemen die in de verticale traditie uitsluitend gekozen politici toekomen, is niet een gevolg van het bestaan van ambtelijke koninkrijkjes. Eigen koninkrijkjes bestonden ook in de bureaucratieën uit het verleden. Het ontstaan van de rol van de 'professionele ambtenaar' heeft een andere oorzaak. Het is een effect van het feit dat de klassieke rol van de ambtenaar niet meer passend is voor een samenleving waarin politiek en overheid in toenemende mate met ongetemde problemen worden geconfronteerd. In zulke gevallen wordt wat er werkelijk aan de hand is pas na het opdoen van de nodige ervaring, na onderzoek en reflectie duidelijk en kunnen verstandige doelen en middelen van beleid dus ook pas gaandewegvaak in samenspraak met niet-statelijke actoren en soms pas tijdens de uitvoering van aanvankelijk geformuleerde beleid - worden geformuleerd. Een boedelscheiding tussen beleidsvoorbereiding, besluitvorming en uitvoering is dan niet staande te houden; een helder onderscheid tussen zaken die deskundigheid vragen en zaken die op het bord van de politiek thuis horen evenmin. In deze niche is de rol van de professionele ambtenaar ontstaan.

De onoverzichtelijkheid van het politiek-bestuurlijke landschap, die onder meer tot uitdrukking komt in het optreden van de 'professionele ambtenaar', is met andere woorden niet veroorzaakt door intern disfunctioneren, maar een effect van het feit dat de overheid moet opereren onder omstandigheden die complexer zijn en met meer onzekerheden zijn beladen dan in het verleden het geval is. De reactie die 'transparantie' en 'verantwoording' vooropstelt, negeert de voorwaarden waaronder de moderne overheid haar werk moet doen. Precies daarin ligt haar tekort.

Het neoliberale gedachtegoed is op dit punt een stap verder. Het onderkent die voorwaarden wel, maar trekt daaruit de conclusie dat de taken te complex zijn voor bureaucratische organisaties en dat de invisible hand van de marktwerking de uitkomst moet brengen die niet langs de weg van de politiek kan worden gerealiseerd. Het vrije spel der maatschappelijke krachten moet de rol gaan vervullen die voorheen aan publieke deliberatie en besluitvorming werd toebedacht; prijsmechanismen nemen de plaats in van overleg en argumentatie. Het neoliberalisme trekt zijn modern klinkende conclusie echter op basis van een wel heel klassiek en in feite verouderd beeld van de overheid.

\subsubsection{COLLECTIEVE LEERPROCESSEN}

Wat in deze beide reacties op de complexiteit en de daaruit voortspruitende onoverzichtelijkheid van de Nederlandse politiek-bestuurlijke verhoudingen over het hoofd wordt gezien, is dat complexiteit niet altijd schadelijk is. De aanwezigheid van zowel verticale als horizontale elementen in ons politieke bestel, de wisselende vormen waarin zij samen optreden en de hoge institutio- 
nele dichtheid waarmee dat gepaard gaat, bieden niet alleen onoverzichtelijkheid, maar ook een rijk bestuurlijk ecosysteem. Daarin bestaat ruimte voor variatie, voor lokale aanpassingen en voor het leggen van contacten die inhoudelijk in plaats van formeel-procedureel zijn geïnspireerd. Dat bestuurlijke ecosysteem mag een onoverzichtelijke aanblik bieden, het biedt ook een omgeving waarin op verschillende niveaus kan worden geleerd en waarin een ruime variëteit aan aanpassings- en correctiemechanismen bestaat. Naast eerste-orde-leerprocessen, waarbij het erom gaat middelen efficiënt af te stemmen op doelen, biedt het ook ruimte voor hogere-orde-leerprocessen, waarin doelen (en daarbij behorende middelen) worden onderworpen aan processen van herijking. Bij zulke hogere vormen van leren worden de (veronderstelde) causale relaties achter de beleidsproblemen en de normatieve uitgangspunten ter discussie gesteld. Leren biedt zich dan aan als het op basis van een rijke verscheidenheid van ervaringen herformuleren van normatieve en cognitieve oriëntaties, van de routines en de spelregels van het beleidsproces.

Een analogie kan dit verhelderen. Een van de meest geavanceerde en succesvolle collectieve leerprocessen die de samenleving kent, wordt zonder enige twijfel gevormd door de moderne wetenschappen. Het wetenschapssysteem vormt, net als de moderne overheid, echter een nogal onoverzichtelijk geheel. Het is een lappendeken van disciplines en subdisciplines, waarin onderzoeksprogramma's ontstaan en weer verdwijnen, individuele onderzoekers in hoge mate hun eigen plan trekken, en waarin elke vorm van centrale regie ontbreekt. Vooruitgang wordt hier niet geboekt door rigoureuze taakverdeling en controle, maar juist doordat onderzoekers in een niet centraal gestuurd proces samenwerken en concurreren. $\mathrm{Zij}$ produceren ervaringen en zorgen door te publiceren ervoor dat andere onderzoekers er kennis van kunnen nemen en die ervaringen kunnen beoordelen, bewerken, corrigeren en verzamelen. Omdat er wordt gepubliceerd ontstaat uit de bijdragen van talloze individuele onderzoekers een niet centraal geleid collectief leerproces. Er vindt feitelijk coördinatie plaats zonder dat er van een coördinator kan worden gesproken.

Dit collectieve leerproces kan zich op verschillende niveaus voordoen. Vaak gaat het om incrementele veranderingen binnen door de beoefenaren van een specialisme geaccepteerde cognitieve en institutionele kaders: instrumenten worden verfijnd, de laatste cijfers achter de komma van de waarde van een parameter worden bepaald. Dit is wat de wetenschapshistoricus Thomas Kuhn (1962) normal science noemt. In andere, meer uitzonderlijke gevallen richt het leerproces zich echter op de kaders die geaccepteerd werden, op de manier waarop problemen werden gesteld, op de stijl van argumenteren en onderzoeken, en daarmee op zaken die impliciet voor vanzelfsprekend werden gehouden. Kuhn spreekt daarbij van revolutionary science. Zulke ingrijpende veranderingen 'paradigmaveranderingen' - blijken zich steeds op verschillende niveaus tegelijkertijd te voltrekken: er ontstaan nieuwe vocabulaires om over een onderwerp te spreken, nieuwe meetmethoden en standaarden, nieuwe vormen van onderlinge communicatie, samenwerking en concurrentie. En dat alles vindt plaats zonder 
centrale regie. Verantwoording vindt steeds op lokaal niveau plaats - met name door het systeem van peer review waarbij wetenschappelijke artikelen vóór publicatie inhoudelijk door collega's worden beoordeeld - en daarbij worden, afhankelijk van de discipline en de stand van het onderzoek, uiteenlopende maatstaven gehanteerd. Op buitenstaanders mag het wetenschapssysteem als geheel de indruk maken van chaos en inefficiëntie. Ondertussen is het wel het meest innovatieve systeem dat zich ooit heeft gemanifesteerd.

Het wetenschapssysteem heeft een aantal kenmerken die doorgaans ook aan de markt worden toegeschreven. Ook daar is (bij een perfect functionerende markt) sprake van een zichzelf corrigerend systeem, dat ontstaat door de aanwezigheid van concurrentie en door het prijssysteem dat onderlinge vergelijking mogelijk maakt, en daarmee dus een vergelijkbare rol speelt als het publicatiesysteem in de wetenschappen (Polanyi 1962). Er bestaat ook een belangrijk verschil. Op de markt vormt wat Hirschman (1972) aanduidt als exit het belangrijkste leermechanisme. Als geproduceerde goederen niet aan de verwachtingen van de klant voldoen of te duur zijn, zal de klant zich tot een andere firma richten. Als de producent zijn producten niet verbetert, zal faillissement volgen. De onderneming die dit lot treft, leert een harde les.

Hirschman wijst er echter op dat naast exit er een ander, meer subtiel terugkoppelingsmechanisme bestaat, dat hij voice noemt. Waar verwachtingen niet worden bewaarheid, kan teleurstelling ook op een andere manier dan door het weglopen naar de concurrent worden gearticuleerd, namelijk door die teleurstelling te verwoorden en inhoudelijk te specificeren. Voice mag traditioneel de manier zijn waarop in de publieke sector op teleurstellende resultaten wordt gereageerd - het vormt een grondtrek van ons politieke systeem -, maar volgens Hirschman zou het onjuist zijn te denken dat mensen met betrekking tot het functioneren van private organisaties alleen de exit-optie hebben. Voor veel private institutionele praktijken geldt namelijk ook dat wie ontevreden is niet meteen naar de concurrent loopt. Het feit dat mensen trouw blijven, ook al zijn zij ontevreden, drukt Hirschman uit in een derde concept: loyalty. Ook op 'de markt' resulteert ontevredenheid niet altijd in exit. Mensen gaan ook met private organisaties voor een kortere of langere termijn relaties aan die behalve een functionele ook een symbolische en emotionele betekenis hebben. Zij verbreken zulke banden niet zomaar. Loyalty geeft een organisatie krediet en gunt haar tijd om te reageren op falen.

Zonder voice-optie vormt loyalty echter geen stimulans om over de kwaliteit en prijs van het aanbod na te denken. Om leerprocessen te stimuleren moeten mensen ongenoegen kunnen uiten. Voice is informatief: zij biedt een organisatie concrete, inhoudelijke aanknopingspunten voor verbetering. Voice kan variëren van klagen tot ervaringen uitwisselen en participatie in de vormgeving van een organisatie. Dit impliceert overigens niet dat iedereen maar voortdurend zijn ervaringen moet communiceren. Effectieve leerprocessen, zo stelt Hirschman, zijn gebaat bij dosering. Dat geldt voor exit, maar ook voor voice. Als iedereen bij 
het eerste het beste falen wegloopt, overleeft een organisatie eenvoudig niet en worden geen leerprocessen in gang gezet. Als iedereen bij voortduring commentaar heeft op van alles, wordt commentaar routinematig en verliest het zijn betekenis.

De wetenschappen kunnen beschouwd worden als een systeem waarin zo'n mix van loyalty, voice en exit bestaat. Een onderzoeker die bij de eerste de beste moeilijkheid waarmee zijn theorie wordt geconfronteerd die theorie aan de kant gooit, zal de wetenschap niet verder brengen. Loyaliteit aan het paradigma en nauwkeurige specificatie in welke opzichten verwachtingen niet bewaarheid werden brengt de wetenschap verder. Voice is de weg die hier moet worden gegaan. De wetenschap als institutioneel systeem functioneert doordat individuele onderzoekers uitgebreid en inhoudelijk articuleren waarin de moeilijkheden die zich aandienden bestaan. In de wetenschappen wordt daarom veel tijd en energie besteed aan het bespreken van - in de ogen van buitenstaanders wellicht onbenullig lijkende - details. Wie daarvoor niet het geduld kan opbrengen zal weinig bijdragen. Uiteraard kan er een ogenblik komen waarop de conclusie getrokken moet worden dat om de problemen op te lossen een radicale herziening van uitgangspunten en dus een paradigmawisseling vereist is. Dat moet echter niet te snel gebeuren. Institutioneel leren gedijt het beste wanneer - in economische termen gesproken - de exit-opties weerspannig zijn en van een zekere mate van institutionele inelasticiteit sprake is.

De leerprocessen waarin overheid en politiek betrokken zijn kunnen niet op alle punten vergeleken worden met die in de wetenschappen. Aan de wetenschappen kan echter in de eerste plaats het besef worden ontleend dat fouten en falen op verschillende manieren, langs verschillende wegen en met uiteenlopende consequenties tot verbeteringen kunnen leiden. Bedrijven mogen in het algemeen het gevoeligst zijn voor de signaalfunctie van exit; in andere sectoren - zoals de wetenschappen - speelt voice een centrale rol. Dit onderkennen mag ook de vanzelfsprekendheid ondermijnen waarmee privatisering en marktwerking als panacee voor het falen van de overheid om complexe taken op een aanvaardbare manier aan te pakken. Naast exit kan ook het verbeteren en organiseren van voice het vermogen om te leren versterken.

In de tweede plaats kan aan de besproken analogie het inzicht worden ontleend dat het verbeteren van voice om meer gecompliceerde leerprocessen mogelijk te maken niet een kwestie is van het simpelweg kanaliseren van informatiestromen tussen overheid en burger door - bijvoorbeeld - het introduceren van referenda. Als voice wordt gestandaardiseerd tot het drukken op de ene of de andere knop, gaat precies het karakter van deze vorm van terugkoppeling verloren - voice ontaardt dan in een vorm van exit. Voice wordt mogelijk als er een systeem bestaat waarin individuele, lokale en op inhoudelijke overwegingen gemaakte afwegingen publiek worden gemaakt, waardoor de verscheidenheid van ervaringen onderling vergeleken, gecombineerd en gecorrigeerd kan worden. Voice vereist dus geduld en een organisatie waarin de tijd wordt genomen om details te 
bespreken. Bij voice is het niet alleen relevant dat er wordt geklaagd, maar ook waarover, in welk opzicht en vanuit welke verwachtingen en welk perspectief. Van voice wordt dus onvoldoende gebruik gemaakt waar ervaringen worden gebureaucratiseerd - waar klachten alleen geuit kunnen worden via voorgedrukte formulieren of een van tevoren bepaalde keuze wordt voorgelegd - of waar informatie wordt gepolitiseerd - waar klachten uitsluitend in beschuldigende termen worden geuit en de enige vraag is wie voor het falen gestraft dient te worden. Wie voice serieus wil nemen zal zich bovendien rekenschap moeten geven van het feit dat in voice altijd zowel cognitieve als normatieve aspecten aan de orde zijn.

Voice moet - net als dat in de wetenschappen het geval is - ondersteund worden door een organisatie waarin ervaringen van falen kunnen worden gearticuleerd en verzameld. Dat kan op uiteenlopende manieren. Zo kan er welbewust gebruik worden gemaakt van maatschappelijke experimenten om ervaringen met beleid te genereren en te evalueren; waar zich klachten aandienen kan mediation helpen om helderheid te krijgen over wat over en weer mag worden verwacht, articulatie kan bevorderd worden door onderzoek naar best practices en het expliciet organiseren van de uitwisseling van ervaringen, door introductie van nieuwe vormen van rapportage (bijvoorbeeld niet alleen van fouten maar ook van near-misses) kan het domein waarover gestructureerde ervaring bestaat aanmerkelijk worden uitgebreid. Hoewel de media bij voice een cruciale rol spelen, vooral in het vragen van aandacht voor incidenten, moet onderkend worden dat ook andere kanalen daarvoor beschikbaar zijn. De afhankelijkheid van de media die hun eigen (onder meer commerciële) logica's kennen, versmalt de oriëntatie van de overheid op problemen. Die versmalling moet niet alleen vanuit democratisch gezichtspunt, zoals vaak gesteld wordt, maar vooral ook in inhoudelijk en normatief opzicht, als zorgwekkend worden gezien. Politici en andere overheidsbestuurders moeten zich realiseren dat er een grote verscheidenheid van middelen bestaat om terugkoppeling via voice te organiseren.

Geïnspireerd door een vergelijking met de wetenschappen heeft Hall (1993) een drietal fases onderscheiden waarin de publieke sector op beleidsfalen reageert. Een verandering van de eerste orde bestaat uit minieme technische bijstellingen van beleidsinstrumenten om de beleidsontwikkeling op het rechte spoor te houden. Wanneer zich beleidsproblemen voordoen, zullen beleidsmakers eerst proberen oplossingen te vinden door kleine wijzigingen in de afstelling van de beleidsinstrumenten aan te brengen. De overkoepelende normatieve legitimiteit van de centrale beleidsdoelen en de cognitieve geldigheid van de beleidstheorie worden niet in twijfel getrokken. Een bezuiniging op de sociale uitgaven of een verlaging van uitkeringen, zonder de wettelijke regelingen aan te passen, zijn voorbeelden van zulke eerste-orde-veranderingen. Wanneer blijkt dat een technisch-incrementele bijstelling onvoldoende soelaas biedt, zullen beleidsmakers naar andere instrumenten omzien en oplossingen langs andere wegen en binnen andere instellingen zoeken en kan van tweede-orde-veranderingen worden gesproken. Als aanpassingen van de eerste en tweede orde niet de gewenste normalisering van beleid opleveren, wordt gaandeweg het gezag van het overkoe- 
pelende beleidsparadigma aangetast. Het besef groeit dat de bestaande instellingen falen en dat een paradigmawisseling nodig is. De politieke druk op het beleidsbestel om een alternatief paradigma te ontwikkelen wordt hoger als het aantal beleidsfiasco's toeneemt. De centrale ideeën achter het beleid en de geaccepteerde normatieve oriëntaties worden nu ter discussie gesteld. Zo'n verandering van de derde orde is de meest radicale stap. Het gevoel van urgentie geeft daarbij voeding aan een publiek bewustwordingsproces, waarbij een politiek en academisch debat ontstaat over de cognitieve geldigheid en normatieve rechtvaardiging van het beleidsparadigma. Terwijl eerste en tweede orde kunnen plaatshebben binnen de bestaande netwerken van het beleidsbestel, kan een verandering van beleidsparadigma, gegeven de hoge mate van politisering van derde-orde-veranderingen, onmogelijk beperkt blijven tot de beleidsgemeenschap van hoge ambtenaren, sectorspecialisten en de politieke elite. Zo'n verandering vereist andere politieke processen dan de keten van delegatie en verantwoording die de verticale traditie biedt.

\subsubsection{VOORDELEN VAN GEMENGDE PRAKTIJKEN}

De besproken combinaties van horizontale en verticale politiek kunnen tegen deze achtergrond opnieuw worden bezien. De vraagstukken die prenatale screening in de jaren tachtig en negentig opwierp konden niet simpelweg beantwoord worden met de bestaande politieke middelen. Algemeen werd onderkend dat de onzekerheden over deze technologie nog te groot waren om een politiek eindoordeel te kunnen geven. Voordat een oordeel mogelijk was, diende er praktische ervaring met de nieuwe techniek te worden verzameld en de normatieve vraagstukken die in het geding zijn in kaart worden gebracht. Dat vereiste de nodige tijd en veel werk. Ook de euthanasiekwestie verzette zich tegen snelle besluiten. Ook hier moesten zowel nieuwe instrumenten - zorgvuldigheidsvereisten in dit geval - als nieuwe normatieve denkbeelden worden ontwikkeld. Met het stakingsrecht was het niet anders. Het besef dat arbeidsconflicten sterk contextafhankelijk zijn heeft de wetgever in dit geval er zelfs toe gebracht definitief af te zien van een regeling binnen het standaard bestuurlijke paradigma van nationale wet- en regelgeving. Lokale, context-afhankelijke beoordeling door de rechter zou de subtiliteit kunnen leveren die met algemeen geldige regelingen niet tot stand zou kunnen worden gebracht.

De veranderingen in het Nederlandse beleidsbestel in de eerste helft van de jaren tachtig laten leerprocessen van de derde orde zien. De werkloosheidscrisis van begin jaren tachtig, de verkiezingen van 1982, de zogeheten 'no-nonsensebenadering' van de nieuwe centrumrechtse coalitie onder premier Lubbers en het Akkoord van Wassenaar, kunnen met reden worden beschreven als een belangrijke omslag in het Nederlandse sociaal-economische beleid. Daarbij is - net in de meeste andere industriële landen - een overgang tot stand gekomen van keynesianisme naar monetarisme, een verandering van het centrale beleidsparadigma van de sociaal-economische politiek. Die overgang is niet alleen een verandering in economisch denken geweest, maar heeft ook institutionele gevolgen gehad. 
Het Akkoord van Wassenaar behelsde immers ook een verschuiving in de manier waarop arbeidsvoorwaardenbeleid tot stand komt: het was een centrale afspraak tot decentralisatie. Door de reeds bestaande vormen van horizontale politiek kon deze overgang in Nederland geleidelijker verlopen dan bijvoorbeeld in het Verenigd Koninkrijk. Het gevolg is geweest dat de winnaars in Nederland minder hoog van de toren bliezen dan elders en de verliezers er minder onder hebben geleden. De Nederlandse economie heeft in de jaren negentig in de vorm van een ongekende groei van de werkgelegenheid de vruchten daarvan kunnen plukken.

De Vreemdelingenwet ten slotte laat een combinatie van verschillende vormen van leren zien. Er was zowel sprake van instrumentele aanpassing als de inzet van nieuwe beleidsmiddelen, met name in de uitvoering. Er is daarbij een belangrijke plek ingeruimd voor evaluatie. De kennis en ervaring van de uitvoerende instanties en anderszins betrokken organisaties met de voorgaande wet zijn gebruikt om verbeteringen aan te brengen en de juiste condities te realiseren waaronder de herziene wet ingevoerd kon gaan worden. Tegelijkertijd kwam een nieuw wetsvoorstel tot stand. Door introductie van externe projectleiding is in de voorbereidende fase expliciet de mogelijkheid opengehouden van derde-orde-leren. Immers, door expliciet het proces van meningsvorming en beïnvloeding door partijen tot onderdeel van het project te maken, is een groot aantal verschillende visies en standpunten gearticuleerd en verzameld op een ingewikkeld en omstreden maatschappelijke vraagstuk. Dat het huidige debat zich heeft verplaatst naar het beleid rondom afwijzing en uitzetting en zich daarbij niet alleen op de uitvoerbaarheid maar ook op de morele aanvaardbaarheid richt, lijkt aan te geven dat het vreemdelingenvraagstuk zich vooralsnog tamelijk permanent in het stadium van fase van hardnekkig probleem bevindt.

Bestuurlijke dichtheid mag dus het bezwaar van onoverzichtelijkheid met zich meebrengen, zij kan ook belangrijke voordelen bieden. Door niet-statelijke organisaties en deskundigen, bedrijven en soms ook georganiseerde burgers expliciet bij de vorming van het overheidsbeleid te betrekken, kan de democratische staat de doelmatigheid van zijn beleid verhogen en een scherper idee ontwikkelen over de normatieve kwesties die rond een probleem in het geding zijn. Dit gebeurt door toevoeging van elementen als kennis van het veld, discussie over ervaringen met degenen die de consequenties van het beleid zullen hebben te dragen, door verbreding van het sociale draagvlak en beleidscontinuïteit en het stimuleren van een positieve waardering van betrokkenheid bij het gezamenlijk oplossen van problemen. Door gebruik te maken van horizontale praktijken verkrijgt de overheid toegang tot additionele deskundigheid en essentiële informatie. Het vergemakkelijkt de communicatie over de cognitieve en normatieve aspecten van complexe beleidsaangelegenheden en bevordert interorganisatorische bestuurlijke coördinatie in de uitvoering.

Het op het eerste gezicht onoverzichtelijke politiek-bestuurlijke bestel biedt dus mogelijkheden om te leren, niet alleen als het om de efficiënte afstemming van middelen op doelen gaat, maar ook op de niveaus die hiervoor als tweede- en 
derde-orde-leren zijn aangemerkt. Er is inhoudelijk overleg op diverse niveaus mogelijk, er kan op relatief kleine schaal geëxperimenteerd worden, niet elke kinderziekte van het beleid leidt tot een epidemie. Het is mogelijk de regels van het spel aan te passen, ervaringen uit te wisselen, gangbare cognitieve en normatieve concepties bij te stellen, zonder dat dit steeds met grootschalige politieke veranderingen gepaard hoeft te gaan. Door de institutionele verdichting wordt het mogelijk om inhoudelijk uit te zoeken wat rond een bepaalde kwestie precies in het geding is en wat het object is waarover de verticale politiek zich uiteindelijk dient te buigen en waarover beslissingen genomen moeten worden. Gedistribueerd over vele actoren en contacten kan collectief het werk worden verzet, en kunnen de ervaringen worden gearticuleerd en verzameld die nodig zijn om nieuwe oplossingen voor de nieuw gedefinieerde problemen te ontwikkelen. In dit proces kunnen compromissen worden geformuleerd die vanuit het gezichtspunt van elk van de betrokken partijen vermoedelijk als second best verschijnen, maar die inhoudelijk kunnen worden uitgelegd als de beste collectieve oplossing die onder de gegeven verhoudingen uit de bus kon komen. In de uitleg van de verdiensten van de output van dit bestuurlijke proces ligt een belangrijk deel van de legitimiteit van de Nederlandse politiek.

\subsection{SPANNINGEN BINNEN HET GEMENGD BEDRIJF}

Het zijn niet de complexiteit en de daaruit voortspruitende onoverzichtelijkheid van de politiek-bestuurlijke verhoudingen in het Nederlandse 'gemengde' politieke bedrijf die het leervermogen van de overheid in de weg staan. Het bestaan van een politiek-bestuurlijk bestel waarin een grote variëteit van actoren actief is en waarin communicatie langs diverse wegen - formeel zowel als informeel plaatsvindt, biedt juist grote kansen voor serieuze leerprocessen. Met dat rijke bestuurlijke ecosysteem moet niet ondoordacht worden omgesprongen. Politieke processen vereenvoudigen, daadkracht vergroten en de bestuurlijke lijnen kanaliseren mogen op het eerste gezicht nastrevenswaardige doelen zijn. Bij hun uitwerking wordt echter al snel de stelregel geschonden die door de eeuwen heen de leidraad van ware heelmeesters is geweest: Primum non nocere, "om te beginnen, breng geen schade toe."

Dat complexiteit van bestuurlijke verhoudingen niet de bron vormt van politiek falen en hardnekkige bestuurlijke problemen wil uiteraard niet zeggen dat er niet andere problemen zijn die om aandacht vragen. Waar twee tradities naast elkaar bestaan, zullen zich immers niet alleen hun verdiensten aandienen, maar ook hun tekorten.

Sommige van die tekorten zijn gemakkelijk aan te wijzen. De horizontale traditie is opmerkelijk zwijgzaam over vraagstukken van legitimiteit. Zonder veel discussie wordt ervan uitgegaan dat, als de uiteenlopende constitutionele voorzieningen worden gerespecteerd en besturen op een kwalitatief juiste wijze plaatsvindt, de uitkomst gezaghebbend is en als algemeen bindend wordt aanvaard. In samenlevingen waarin pluriformiteit niet alleen aanwezig is, maar ook assertief wordt 
beleden, is dat een nogal optimistische veronderstelling. Het serieus nemen van voice en het zorgvuldig gebruiken ervan - zonder dat elke klacht op face value wordt aanvaard, maar juist als aanleiding wordt gezien voor nader onderzoek - is voor het verkrijgen van legitimiteit een eerste vereiste. Uitgebreide uitleg over compromissen die bereikt worden en die voor de betrokken partijen second best maar voor de samenleving als geheel optimaal zijn, zal bovendien nodig zijn om draagvlak te verzekeren. In een democratie dienen mensen serieus genomen te worden. Dat wil niet zeggen dat zij op iedere wenk worden bediend, maar dat uitgelegd wordt in welke opzichten met hun wensen rekening is gehouden en ook waarom in voorkomende gevallen die wensen niet zijn gehonoreerd.

De verticale traditie kent een blinde vlek die in zeker opzicht hiervan het directe tegendeel vormt. De vraag hoe de voor kwalitatief goede besluitvorming noodzakelijke kennis en normatieve inzichten gemobiliseerd worden, krijgt binnen deze traditie weinig aandacht. Daarvoor wordt simpelweg naar verkiezingen, parlementair overleg en het beraad in kabinet verwezen. De feitelijke rol die niet-statelijke actoren zoals experts en ngo's spelen, blijft buiten zicht. In hedendaagse samenlevingen beschikken echter niet alleen burgers over de nodige assertiviteit, dat geldt ook voor experts en ngo's. Hun rol in de manier waarop de politieke agenda tot stand komt en beleid vorm krijgt kan niet worden genegeerd.

Bij alle nadruk die de verticale traditie op legitimiteitskwesties legt, wordt tamelijk achteloos omgegaan met een belangrijke voorwaarde voor het feitelijk functioneren van de democratie in een moderne samenleving. Namelijk met het feit dat een groot deel van de politieke problemen die zich aandienen de inbreng vereist van deskundigheid die niet in de keten van delegatie en verantwoording gevonden kan worden. Terwijl in de horizontale traditie onvoldoende aandacht bestaat voor de vraag wie uiteindelijk verantwoordelijkheid voor de regie neemt, verdwijnt in de verticale traditie het zicht op het gegeven dat de overheid, naast anderen, ook de rol van speler vervult.

Andere gevaren dienen zich eveneens aan. De voordelen van een politiek-bestuurlijk stelsel met een hoge dichtheid kunnen gemakkelijk tenietgedaan worden als er zich situaties voordoen waarin partijen elkaar in een verlammende greep houden. De cognitieve en normatieve voordelen die intensieve uitwisseling van ervaringen en overleg bieden, kunnen bovendien gemakkelijk in hun tegendeel omslaan. Dat gebeurt bijvoorbeeld wanneer zulk overleg alleen in kleine kring plaatsvindt - bewust, omdat men geen pottenkijkers duldt, of onbedoeld, omdat de bestuurlijke haarvaten die communicatie met andere maatschappelijke sectoren zouden moeten verzorgen, zijn dichtgeslibd. In het maatschappelijk middenveld zijn voorbeelden aan te treffen van structuren die hierdoor gekenmerkt worden. Ook hier kan op een pendant voor de verticale traditie worden gewezen. Een overheid die primair oog heeft voor haar interne functioneren, en alle energie investeert in het beter laten verlopen van de eigen processen, sluit zich gemakkelijk af van relevante maatschappelijke ontwikkelingen die zich buiten de eigen gezichtskring afspelen. Het kan ook tot gevolg hebben dat obsolete horizontale praktijken ondersteund worden ten koste van nieuwe initiatieven. 
Geen van de genoemde problemen wordt echter verlicht door de - door de dominante verticale traditie in het denken over politiek geïnspireerde - aanpak die in het voorgaande reeds enkele malen is bekritiseerd. Verstandiger lijkt het te onderkennen dat een spanning kan bestaan tussen het horizontale idee dat in redelijkheid en gericht op kwaliteit bestuurd moet worden en de verticale notie dat de legitimiteit van overheidsbeslissingen uiteindelijk bij de kiezers berust. Die spanning kan zich in verschillende vormen manifesteren. Daarbij gaat het steeds om inhoudelijke en normatieve afwegingen die moeten worden gemaakt, niet om procedureel falen.

Dat kan geillustreerd worden door twee vormen waarin die spanning zich aandient nog eens onder de loep te nemen: in de eerste plaats die tussen deskundigheid en democratische legitimiteit en in de tweede plaats die tussen de wens in te spelen op specifieke, bijvoorbeeld lokale contexten ('maatwerk') en de eis van gelijke behandeling die met de rechtsstaat is verbonden.

\subsubsection{DESKUNDIGHEID VERSUS DEMOCRATISCHE LEGITIMITEIT}

Een eerste vorm waarin de spanning tussen de horizontale en de verticale traditie zich aandient kan als een simpele vraag worden geformuleerd: moet de legitimiteit van het overheidsbeleid over (technisch) ingewikkelde aangelegenheden zeg: de veiligheid van kernenergie, of de wenselijkheid van de introductie van een nieuwe vorm van prenatale screening - in de eerste plaats gezocht worden in een zo ruim mogelijke democratische betrokkenheid, of dienen beslissingen hierover te worden genomen op basis van het raadplegen van de beste experts die beschikbaar zijn?

Het - triviale - antwoord op deze vraag luidt uiteraard: beide zijn nodig. Een moderne overheid heeft voor haar beleid zowel deskundig advies als politiek draagvlak nodig. De vraag is hoe in een specifiek geval beide verenigd kunnen worden en de balans tussen kennis en macht moet worden bepaald. Dat antwoord - en wat kan er meer worden gezegd? - biedt uiteraard weinig verlichting. Waar slechts oninteressante antwoorden gegeven worden, deugt echter vermoedelijk de vraagstelling niet. Daarop moeten we dan ook om te beginnen onze aandacht richten.

Waar, zoals in bovenstaande vraag, 'kennis' en 'macht', of het 'horizontaal' raadplegen van deskundigen en het 'verticaal' in meerderheid parlementair beslissen tegenover elkaar worden gesteld, draait het uiteindelijk om de vraag tegenover wie - deskundigen of leken - bestuurders hun besluiten moeten legitimeren. Die vraag is echter eenvoudig te beantwoorden. De verticale traditie levert hierop het antwoord - hetgeen niet verwonderlijk is, want deze traditie is precies met het oog op dit soort vragen ontstaan. Het antwoord is dan ook klip en klaar. Deskundigen mogen adviezen geven, beslissen doet de politiek. Uiteraard zullen politici er verstandig aan doen om goed naar de geleverde adviezen te luisteren, maar politieke vertegenwoordigers hebben zich uiteindelijk te verantwoorden tegen- 
over de kiezers en niet tegenover hun adviseurs. Ook waar neoliberale economen pleiten voor het overdragen van politieke beslissingen naar de werking van de markt, staat niet ter discussie dat privatisering een politiek besluit vereist dat door regering en de Kamer moet worden genomen en waarover politici zich tegenover kiezers dienen te verantwoorden. Ditzelfde geldt voor de opstelling van deskundigen. Toen het kabinet in november 2003, met latere steun van de Kamer maar tegen het advies van de Gezondheidsraad en de mening van het overgrote deel van de betrokken professionals in, besloot het aanbod van kansbepalende prenatale screening te beperken tot vrouwen boven 36 jaar, was de legitimiteit van dat besluit op geen enkele manier in het geding. Zeker, er werd gemopperd en in de media is de wijsheid van het genomen besluit betwist. De betrokken medische professionals hebben zich echter bij het politieke oordeel neergelegd, en hun organisaties hebben zich - met de overheid - vervolgens gebogen over de wijze waarop het democratisch tot stand gekomen beleid kon worden uitgevoerd. Het besef dat als het op politieke beslissingen aankomt regering en parlement het laatste woord hebben is - gelukkig - feitelijk onomstreden. De spanning waar de gestelde vraag van uitgaat doet zich, als we ons op het legitimeren van een gegeven besluit richten, daarom feitelijk niet voor.

In de situatie waarin nog niet duidelijk is welke aspecten bij een kwestie die in het geding is relevant zijn, is het antwoord minder simpel. Een verstandig bestuurder zal zowel luisteren naar wat deskundigen te berde te brengen hebben, als wat uiteenlopende maatschappelijke groeperingen die met de kwestie van doen hebben - of zullen hebben - inbrengen. Daarbij kan uiteraard een spanning optreden tussen de gezichtspunten van experts en van betrokken groepen. Meestal zijn de scheidslijnen echter grilliger. Juist in kwesties waarover onzekerheid heerst zullen zowel betrokken maatschappelijke groeperingen als deskundigen ook onderling van mening verschillen. Wat zich in deze situatie aandient is daarom een tegelijkertijd inhoudelijk en bestuurlijk probleem, namelijk de vraag hoe bevorderd kan worden dat relevante ervaringen, belangen en gezichtspunten op een serieuze en evenwichtige manier gearticuleerd en bijeengebracht kunnen worden. Wiens oordelen en meningen moeten worden gemobiliseerd, wie moet in de oordeelsvorming betrokken worden, welke deskundigen en welke maatschappelijke groeperingen moeten - naast degenen die zich reeds spontaan meldden - expliciet worden uitgenodigd om hun visies te geven?

Bij die vraag draait het er niet om dat iedereen zijn zegje heeft kunnen doen. De inhoudelijke vraag welke ervaringen en inzichten nog ontbreken voor een redelijk besluit genomen kan worden dient voorop te staan. Behalve van degenen die zich luid en duidelijk roeren, dienen relevante ervaringen en gezichtspunten naar voren gebracht en verzameld te worden van partijen die zich niet spontaan melden, maar die wel tot het relevante publiek gerekend moeten worden, omdat zij met de gevolgen van een kwestie te maken hebben. Het bestuurlijke probleem dat moet worden opgelost is hoe voice op een zodanige manier kan worden georganiseerd dat de relevante gezichtspunten naar voren komen en elk op hun waarde kunnen worden onderzocht. Dat is geen bestuurskundig probleem dat 
door een rondje medezeggenschap te organiseren kan worden opgelost, maar een inhoudelijke kwestie. Het issue dat aan de orde is bepaalt in zekere zin van wiens inzichten en ervaringen gebruik moet worden gemaakt om een beter zicht te krijgen op de zaak. One size fits all-oplossingen zijn hiervoor niet beschikbaar. Een bestuurder die voor volksgezondheidsproblemen wordt gesteld zal andere partijen moeten uitnodigen dan zijn collega die de milieu- of werkgelegenheidsproblemen op zijn bord heeft.

De eerder behandelde voorbeelden kunnen wederom als illustratie dienen. In het geval van de euthanasiekwestie heeft de rechter deze bestuurlijke rol op zich genomen. In de rechtszaal zijn in opeenvolgende processen getuigen-deskundigen geraadpleegd, in de publieke discussies die zich naar aanleiding van de rechterlijke uitspraken hebben ontwikkeld zijn de uiteenlopende partijen aan het woord geweest, en die discussies hebben in daaropvolgende processen weer een rol gespeeld. Al met al is de tijd genomen voor een evenwichtige oordeelsvorming. In het geval van de prenatale screening heeft het proces zich - zonder centrale regie - voltrokken door de intensieve wisselwerking tussen onderzoekers, de Gezondheidsraad, ambtenaren, medische beroepsgroepen en ethici. Ook hier is sprake geweest van een zich ontwikkelende meningsvorming, zijn gaandeweg nieuwe inzichten geformuleerd en is gebruik gemaakt van ervaringen die in pilot-studies zijn opgedaan.

Voor het genoemde inhoudelijk-bestuurlijke probleem bestaat dus geen sluitende oplossingsregel. Het zijn uiteindelijk de kwaliteiten van de betrokken politici-al of niet ondersteund door geformaliseerde raadplegingseisen - die voor het goede verloop van de oordeelsvorming garant moeten staan. Daarbij mag verwacht worden dat zij enerzijds de tijd nemen om serieuze oordeelsvorming mogelijk te maken, maar anderzijds in het besef handelen dat in een moderne samenleving moesjawara geen optie is. Uiteindelijk zal het 'horizontale' politieke proces in een besluit moet uitmonden. In die fase aanbeland gelden de hierboven gemaakte kanttekeningen. Voor het nemen en legitimeren van uiteindelijke besluiten bestaan de 'verticale' procedures van de parlementaire democratie. Van een spanning tussen deskundigen en leken kan zo beschouwd niet worden gesproken. Hooguit bestaat er een spanning tussen politici die haast hebben en degenen die van oordeel zijn dat er langer moet worden nagedacht voor een besluit genomen kan worden dat niet alleen legitiem, maar ook als redelijk kan worden aangemerkt.

\subsubsection{RECHTSSTAAT EN POLITIEK MAATWERK}

Een overeenkomstige beschouwing kan worden gegeven voor een tweede vorm waarin de spanning tussen horizontale en verticale politiek zich aandient, namelijk die tussen enerzijds de eis dat in een rechtsstaat gelijke gevallen gelijke behandeling behoeven en anderzijds het idee dat 'maatwerk' noodzakelijk is, dat rekening gehouden moet worden met contextuele factoren, zoals lokale omstandigheden. Ook hier wordt de soep echter niet zo heet gegeten als ze wordt opgediend. 
Om te beginnen is het weinig zinvol deze spanning buiten de inhoudelijke kwestie die in het geding is om te bespreken. Dat er in verschillende gemeenten niet dezelfde tarieven bestaan voor wie na verlies van zijn paspoort een nieuw aanvraagt, zal niet meteen tot opwinding leiden; zulke verschillen brengen de rechtsstaat niet in gevaar. De burger mag echter wel eisen dat de voorwaarden waaronder een verzoek tot uitreiking van een paspoort ingewilligd, respectievelijk geweigerd wordt, in alle gemeenten dezelfde zijn. Daarbij is de rechtszekerheid van de burger wel in het geding. De kwestie is in de eerste plaats dus een zaak van maatvoering.

Ook hier is het van belang de fases waarin het politieke proces zich bevindt te onderscheiden. Als we de aandacht richten op een gegeven kwestie levert de verticale traditie ook in dit geval het algemeen geaccepteerde antwoord. De vraag wat de bevoegdheden van lokale bestuurders zijn en over welke kwesties zij lokaal kunnen beslissen is immers landelijk, wettelijk geregeld. Het zijn dus uiteindelijk regering en parlement die beslissen hoe deze verhoudingen liggen. Zo kan de landelijke politiek beslissen dat een groot aantal beleidsvraagstukken en uitvoeringskwesties die voorheen onder de AWBZ vielen, vanaf 1 januari 2007 op basis van de nieuwe Wet Maatschappelijke Ondersteuning (WMO) onder de verantwoordelijkheid van de gemeenten zullen vallen (Peters 2006). Zodra de WMO is aangenomen, kan - vanuit het perspectief van de verticale traditie bezien - niet langer van een 'spanning' tussen rechtsstatelijke beginselen en lokaal maatwerk gesproken worden. Er is democratisch besloten eventuele verschillen tussen gemeenten die als gevolg van deze wet zullen ontstaan op dezelfde manier te bezien waarop de variëteit in de paspoorttarieven wordt beschouwd. Dat oordeel kan uiteraard in de loop van de tijd - als er meer ervaring met de uitvoering van de WMO bestaat - veranderen; in dat geval zal de wet eventueel moeten worden aangepast. Aan het principe doet dat echter niets af: de (landelijk vastgestelde) wet definieert wat onder de 'rechtsstaat' valt en dus wat burgers op het gebied van rechtszekerheid mogen verwachten.

Dat uiteindelijk de landelijke politiek de regels stelt waarbinnen lokale overheden opereren, vertelt echter weinig over de manier waarop, en de onderwerpen waarover, voorafgaand aan zo'n besluit tussen landelijke en lokale bestuurders, alsmede - in het geval van de WMO - een brede kring van betrokkenen (zoals gehandicapten- en ouderenorganisaties, uitvoeringsorganisaties en deskundigen op het terrein van de sociale zekerheid) over een dergelijke kwestie moet worden overlegd. Een beroep op de verticale legitimiteit, op afspraken in een regeerakkoord en een te verwachten parlementaire meerderheid, zijn dan weinig zinvol, zo niet contraproductief, voor serieus inhoudelijk overleg. Voor het bespreken van de kwesties die in het geding zijn, de voorwaarden waaronder het voorgenomen beleid succesvol uitgevoerd kan worden en de rechtsstatelijke en (lokaal)politieke consequenties die de Wet op de Maatschappelijke Ondersteuning zal hebben, behoren - vanuit de horizontale traditie bezien - behalve degenen die een afspraak in het regeerakkoord hebben gemaakt, ook degenen aan het te woord komen die met de vermoedelijke consequenties van zo'n afspraak geconfronteerd 
zullen worden. Dat gezien het regeerakkoord er een parlementaire meerderheid voor een wet zal bestaan, is vanuit die traditie bezien onvoldoende grond om van redelijk bestuur te kunnen spreken. De spanning tussen gelijkheid voor de wet en maatwerk is dus ook in dit geval een inhoudelijk politiek probleem dat politiekbestuurlijke kwaliteiten eist. Het kan niet door een formele beslisregel worden beslecht. Waar het (verticaal gemotiveerde) machtswoord te vroeg valt, wordt vanuit de horizontale traditie bezien geen politiek bedreven, maar is sprake van misbruik van politieke middelen.

De Wet bijzondere maatregelen grootstedelijke problematiek, ook wel de 'Rotterdamwet' genaamd, biedt in dit opzicht een interessante casus. De gemeente Rotterdam heeft op grond van deze wet speciale bevoegdheden gekregen om maatregelen te nemen op het terrein van de criminaliteitsbestrijding, veiligheid, sociale cohesie en allochtonenbeleid. De wet spruit voort uit een constatering die door het Rotterdamse college van Burgermeester en Wethouders in 2003 als volgt is verwoord.

\footnotetext{
"Het absorptievermogen van bepaalde wijken wordt overschreden door een blijvende instroom van kansarmen en het vertrek van kansrijken die zich kunnen veroorloven elders te gaan wonen. Samen met de overlast, illegaliteit en criminaliteit is dat voor ons de kern van het probleem. [...] Buurten in nood vereisen wetgeving die toegesneden is op de bijzondere omstandigheden. Daartoe moet generieke wetgeving de mogelijkheid bieden uitzondering te bieden naar tijd, plaats en omstandigheden." (geciteerd in Hertog 2006)
}

Het kabinet is daarom gevraagd om de Huisvestingswet zodanig te veranderen dat de gemeente sociaal-economische minimumeisen kan stellen aan degenen die zich in Rotterdam willen vestigen.

Die eis is - met enige aanpassingen - door het kabinet en het parlement gehonoreerd: gemeenten hebben (tijdelijk) de mogelijkheid gekregen om in gebieden met leefbaarheidsproblemen inkomenseisen te stellen aan woningzoekenden. Door onder meer de Raad van State, het Landelijk bureau ter bestrijding van rassendiscriminatie en de Commissie Gelijke Behandeling is echter forse kritiek op de wetsvoorstellen geuit: deze zouden kunnen leiden tot beleid dat in strijd is met de Algemene wet gelijke behandeling en daarmee op gespannen voet staan met elementaire rechtsstatelijke beginselen. Het kabinet heeft die bezwaren echter naast zich neergelegd.

Over de legitimiteit van de inmiddels aangenomen Rotterdamwet kan geen misverstand bestaan. Die heeft kracht van wet. Bij het bestuurlijke proces kunnen wel de nodige kanttekeningen worden gemaakt. Daarbij is niet de vraag of de politiek wel voldoende besef heeft gehad voor de spanning tussen de door het Rotterdamse college naar voren gebrachte overwegingen en het gelijkheidsbeginsel. Door de commentaren die onder meer vanuit de Raad van State zijn geleverd kan over die spanning geen misverstand bestaan. Ook het kabinet en de 
Kamer zijn zich daar uiteraard bewust van geweest. De vraag is of dit besef niet tot een andere vorm van politiek gedrag had kunnen leiden, namelijk een waarin het besef dat die spanning bestaat als een serieus te nemen politiek probleem zou zijn onderkend, in plaats van dit besef per fiat te negeren.

De maatregelen die in de Rotterdamwet zijn vastgelegd hadden bijvoorbeeld expliciet als experiment kunnen worden ingericht. Daarbij gaat het om meer dan het afspreken van een termijn waarna men de zaken nog eens bekijkt en op basis van het al dan niet halen van eerder vastgestelde 'targets' conclusies trekt. Bij een serieus experiment zouden de ervaringen die met de gesignaleerde spanning verbonden zijn op lokaal en nationaal niveau verzameld moeten worden en onderwerp van overleg moeten zijn. Gaandeweg zou dan een beter zicht ontstaan op doelen en middelen en hun onderlinge verhouding. De Nederlandse samenleving had zo kunnen leren hoe met dit belangrijke en gevoelige onderwerp kan worden omgegaan. Daarbij had onderzocht kunnen worden of en zo ja op welke manier, door het herformuleren van de problemen, het nader specificeren van doelen of het nemen van additionele maatregelen, aan de aanvankelijk in principiële termen geformuleerde bewaren tegemoet had kunnen worden gekomen. Hoe kan het rechtsstatelijke gelijkheidsbeginsel naar specifieke lokale omstandigheden worden vertaald? Welke vormen van verantwoording - door de lokale en door de nationale overheid - zijn dan gepast? Vereist een inperken van het gelijkheidsbeginsel wellicht de introductie van nieuwe mogelijkheden om in beroep te gaan? Of zijn de beschikbare voorzieningen toereikend? Het antwoord op zulke vragen is allerminst zeker. Door ze niet in enigerlei vorm te stellen, heeft de wetgever zichzelf echter de mogelijkheid ontnomen te laten zien dat in deze kwestie in redelijkheid is bestuurd. De haast waarmee de wet is ingevoerd en het gemak waarmee de principiële bezwaren aan de kant zijn geschoven, wijzen erop dat onvoldoende onderkend is dat er onzekerheid bestaat over de manier waarop de problemen waarvoor het Rotterdamse college zich gesteld zag en de rechtsstatelijke beginselen op elkaar moeten worden afgestemd.

\subsection{CONCLUSIE}

De onoverzichtelijkheid van het bestuurlijke en politieke landschap in Nederland hoeft op zichzelf geen probleem te zijn. Deze biedt juist kansen voor maatschappelijke leerprocessen waarbij de politiek - horizontaal en verticaal - een creatieve en doorslaggevende rol speelt. Problemen dienen zich aan daar waar de publieke zaken die de overheid behartigt inhoudelijk en normatief onvoldoende worden onderkend en waar - om wat voor reden dan ook - niet of nauwelijks gebruik wordt gemaakt van de bestaande deskundigheid. De tijd die nodig is om uit te zoeken wat precies in het geding is wordt niet genomen. De ervaringen met bestaand beleid worden onvoldoende gearticuleerd, verzameld en op hun belang geschat. Bij een overheid die complexe problemen serieus neemt, horen geen pleidooien voor het vereenvoudigen van politieke processen, het vergroten van daadkracht en het kanaliseren van bestuurlijke verhoudingen. Hetzelfde geldt voor shortcuts die erop gericht zijn om - mogelijk ondoordachte - kiezerswen- 
sen, zonder dat zij kritisch worden beschouwd, in daden om te zetten. Bij complexe problemen geldt nu eenmaal dat niet het eerste idee dat wordt geuit ook altijd het beste is, noch dat wat het luidst wordt geroepen de hoogste kwaliteit heeft. In een democratie hebben kiezers het laatste woord; van serieuze bestuurders mag echter gevraagd worden dat zij ervoor zorgen dat daarvóór de geluiden kritisch worden beoordeeld.

Een gemengd politiek bedrijf biedt mogelijkheden voor een bestuur dat zich richt op inhoudelijke redelijkheid en democratische legitimiteit. De spanningen die zich daarbij voordoen dienen aanleiding te zijn voor inhoudelijk overleg en bestuurlijke creativiteit. Om deze mogelijkheden optimaal te kunnen benutten, en spanningen binnen het gemengd bedrijf constructief aan te wenden, is het nodig dat op het juiste moment wordt geschakeld tussen horizontale en verticale praktijken. Ook de vormgeving van horizontale processen is van belang. Voice moet ondersteund worden door een organisatie waarin ervaringen van falen kunnen worden gearticuleerd en verzameld. Door niet-statelijke actoren te betrekken bij de vorming van overheidsbeleid kan een collectief leerproces ontstaan waarin de democratische staat de doelmatigheid van zijn beleid verhoogt en een scherper idee ontwikkelt over de normatieve aspecten van problemen. Een belangrijke voorwaarde voor het welslagen van dit leerproces is het serieus nemen van de feitelijke rol van ambtenaren. Democratie mag - naar het cliché - geen systeem zijn voor bange mensen; het is ook geen systeem voor gemakszuchtige bestuurders. 


\section{EEN PROBLEEMGERICHTE BENADERING}

\section{$5.1 \quad$ INLEIDING}

Politiek en overheid, zo hebben wij in de vorige hoofdstukken laten zien, functioneren in een complex krachtenveld. Met de hier gepresenteerde aandacht voor werkwijzen die niet alleen uitgaan van het primaat van het bevoegd gezag en de hiërarchie, maar juist ook de meer horizontale praktijken koesteren, vragen we aandacht voor een andere benadering van problemen. We streven daarmee naar herstel van de uitgesproken trots op de overheid als organisatie en op wat overheid en politiek bijdragen aan het welbevinden van burgers.

Politiek en overheid vervullen verschillende rollen: zij zijn tegelijk opdrachtgever en uitvoerder, wetgever en dienstverlener, en borgen de toegankelijkheid en kwaliteit van voorzieningen die zij zelf niet leveren. Die verschillende rollen doen zich vooral gelden bij maatschappelijke vragen en problemen die normatief omstreden of onhelder zijn en cognitief onzeker, dat wil zeggen ongetemde problemen. Overheid en politiek behoren immers niet alleen in staat te zijn gezaghebbend te oordelen en besluiten te nemen, maar ook in staat te zijn langdurig en goed georganiseerd te leren hoe maatschappelijke problemen aan te pakken. Bij normatief omstreden kwesties is er sprake van verschil van opvatting over de definitie van het probleem en/of over de beoordeling van de gewenste uitkomst of oplossing. Bij cognitief onzekere problemen is er sprake van onvoldoende kennis over de aard van het probleem, de oorzaken ervan of de meest effectieve oplossing. We hebben voorbeelden genoemd zoals de invoering van de Vreemdelingenwet, het economisch beleid in de jaren tachtig en negentig, de euthanasieproblematiek en het stakingsrecht.

Overheid en politiek leveren een bijdrage aan oplossingen voor deze ongetemde en soms ook hardnekkige maatschappelijke problemen, maar zij doen dat niet alleen. Ook andere actoren zijn hard nodig om tot een maatschappelijk aanvaardbare uitkomst te komen. De paradox is dat voor het oplossen van deze hardnekkige problemen overheid en politiek primair als hoogste gezag worden aangesproken, terwijl zij bij uitstek in die situatie het minst bij machte zijn om die rol te vervullen. Alleen in samenspraak met anderen zijn legitieme en effectieve oplossingen mogelijk.

Het vervullen van verschillende rollen is naar het oordeel van de raad inherent aan het wezen van overheid en politiek. Juist bij ongetemde problemen is het kunnen putten uit verschillende repertoires die passen bij de aard van het vraagstuk, van belang. Bijvoorbeeld naast vormen van centrale sturing ook het werken met een meer open agenda met in eerste aanleg algemene afspraken en richtlijnen, het organiseren van feedback-mechanismen om te leren van experimenten en eerste ervaringen, het benutten van de kennis en ervaring van verschillende 'publieken' (Dewey 1927) zoals groepen burgers, bedrijven of instellingen en de 
meer formele dan wel informele samenwerkingsverbanden waarin zij participeren. We hebben in de vorige hoofdstukken voorbeelden van deze repertoires beschreven.

In het huidige discours wordt het belang van het gebruik van verschillende repertoires niet zonder meer erkend. Integendeel, het verbeterprogramma voor politiek en overheid wordt gearticuleerd in een taal die de politiek als het hoogste gezag aanmerkt en de overheid als efficiënt uitvoeringsorgaan. Een onderscheid naar de aard van het probleem wordt daarbij meestal niet gemaakt. Wat nodig is zo luidt een thans veel gehoorde opvatting - is daadkracht en doorzettingsmacht, een regering die leiderschap toont en weet waarvoor zij staat, een politiek die handelt naar wat de kiezer wil en die ook weet te realiseren wat is besloten. Hier gaat het om het herstellen en borgen van de legitimiteit van overheid en politiek. Het verbeterprogramma is in deze lijn van denken gericht op een verbetering van de effectiviteit van het overheidshandelen. Dit neemt de vorm aan van een duidelijke scheiding tussen beleid en uitvoering, tussen politiek en ambtenaren, een beter beheer van en controle op de uitvoering en daar waar dat doelmatiger is, het overhevelen van taken naar de markt. Pas dan is ook de legitimiteit van het overheidshandelen veilig gesteld. Het parlement is vooral gericht op zijn controlerende taak en de overheid vooral op het managen van processen. Dat is waar ze zich in toenemende mate op laten voorstaan, en daar worden zij ook op aangesproken.

Naar het oordeel van de raad leidt zo'n pleidooi tot een vorm van politiek en overheidshandelen die inhoudelijk en normatief 'leeg' is. De maatschappelijke kwesties worden onvoldoende aan een kritisch onderzoek onderworpen, er wordt te weinig gewikt en gewogen. Normatieve vragen en inhoudelijke afwegingen verdwijnen naar de achtergrond ten gunste van een benadering die het proces, de procedure, het resultaat en (bij voorkeur kwantitatieve) verantwoording centraal stellen. Dit alles wordt versterkt door de behoefte - de noodzaak zelfs - aan duidelijke profilering om de kiezer gunstig te stemmen. In zo'n klimaat wint de keuze voor de stellige uitspraken het van lastige boodschappen, de constructieve dialoog, de bezinning en het onderzoek. Hiermee is uiteraard niet gezegd dat beslissen en doorzetten altijd verkeerd zouden zijn. De analyse uit de voorgaande hoofdstukken laat echter zien dat vooral bij ongetemde problemen aanvullende benaderingen mogelijk en gewenst zijn. In die situaties is niet het gebrek aan doorzettingsmacht, daadkracht en snelheid de kern van het probleem waar politiek en overheid mee worstelen. Kernprobleem is het verlies van een inhoudelijke en normatieve oriëntatie, en daarmee het verlies aan weerbaarheid en veerkracht om ingewikkelde kwesties situationeel - dat wil zeggen op maat gesneden - aan te pakken.

Juist wanneer politiek en overheid worden aangesproken op hun vermogen met hardnekkige maatschappelijke problemen om te gaan, is het van belang dat ze vanuit schijnbaar strijdige rollen weten te oordelen en handelen. Met ons pleidooi voor een inhoudelijke en meer normatieve oriëntatie kiezen wij daarom voor een probleemgerichte benadering. De aanpak is geënt op een analyse van het 
probleem zelf, procedures bieden een context waarbinnen een inhoudelijk standpunt wordt ontwikkeld. Het zoeken naar passende probleemdefinities, het betrekken van verschillende publieken en het verzamelen van verschillende bronnen van kennis en ervaring 'wint' het als het ware van een benadering waarbij posities het vertrekpunt zijn.

De vele voorgenomen en soms ook gerealiseerde reorganisaties van en binnen de rijksdienst gaan juist de kant op van het versterken van het denken in termen van posities en structuren. Zo zou bijvoorbeeld het instellen van kerndepartementen of het geven van meer bevoegdheden aan bewindslieden op bepaalde 'dossiers' of het versterken van de positie van de minister-president als structuurmaatregel zonder meer bij moeten dragen aan het probleemoplossend vermogen van de overheid. Bij deze voorstellen is niet de inhoudelijke agenda van overheid en politiek het vertrekpunt, maar de verantwoordelijkheidsverdeling. Maar als niet eerst een inhoudelijk programma wordt opgesteld, waar juist vanuit verschillende perspectieven naar bijvoorbeeld jeugd of veiligheid wordt gekeken, heeft het weinig zin een nieuwe organisatiestructuur voor te stellen. Juist bij kwesties die normatief omstreden zijn en cognitief onzeker, is het van belang de wendbaarheid, veerkracht (Van Gunsteren 2006) en de expertise van de overheid op verschillende plaatsen te borgen en te versterken.

Dit hoofdstuk is als volgt opgebouwd. In de volgende paragraaf (5.2) geven we een korte samenvatting van onze belangrijkste bevindingen. In het bijzonder gaan we in op de rijkdom van het 'gemengd bedrijf' en de eenzijdige beoordeling ervan. Vervolgens gaan we in paragraaf 5.3 in op wat naar ons oordeel de gevolgen hiervan zijn voor het leervermogen van politiek en overheid. Paragraaf 5.4 bespreekt de omslag die nodig is om een meer inhoudelijke en normatieve oriëntatie centraal te stellen en daarbij de verschillende rollen van politiek en overheid optimaal te benutten. Hierbij gaan wij specifiek in op de gevolgen van deze omslag voor het functioneren van de politiek, de regering en het ambtelijk apparaat. Deze omslag is vooral van belang voor het kunnen aanpakken van ongetemde problemen die nu en in de toekomst nadrukkelijk op het bord van de overheid terechtkomen.

\subsection{HET GEMENGD BEDRIJF}

\subsubsection{TWEE TRADITIES}

In onze analyse van het functioneren van politiek en overheid hebben wij een onderscheid gemaakt tussen twee tradities die wij de verticale en de horizontale traditie hebben genoemd. De beide tradities verschillen in de manier waarop over politiek geargumenteerd wordt en in de manier waarop het politieke handelen dient te zijn georganiseerd. Elke traditie hanteert een eigen perspectief op politiek en propageert een daarbij horende praktijk. De beschrijving van deze twee tradities komt uitvoerig aan de orde in hoofdstuk 3 . We geven hier een korte samenvatting. 
In de verticale traditie heeft 'politiek' betrekking op de manier waarop de verhouding tussen staat en burgers geregeld wordt. Formele legitimiteit gericht op posities (de wie vraag) staat daarbij voorop. De relevante actoren zijn burgers die als kiezers optreden, de parlementariërs die hen representeren, de regering en de uitvoerende macht. Hun formele rollen en verhoudingen zijn procedureel, in het staatsrecht vastgelegd. Er bestaat een formele keten van delegatie en verantwoording. Tussen elk van de schakels van deze keten bestaat de verhouding van principaal tot agent. Daarbij is de eerste bevoegd bindende besluiten te nemen. De laatste dient deze besluiten uit te voeren of is door de principaal gemachtigd beslissingen te nemen in zijn naam en plaats. In deze keten vindt in de ene richting delegatie van macht plaats, terwijl in omgekeerde richting sprake is van een verantwoordingsverplichting. De wetgever ontleent zo zijn macht uiteindelijk aan de kiezers; de uitvoerende macht voert uit wat de wetgever heeft besloten.

De horizontale traditie verstaat onder 'politiek' een bijzondere manier om in een samenleving orde te scheppen en gecoördineerd, gemeenschappelijk handelen mogelijk te maken. 'Politiek' wordt opgevat als die vorm van besturen waarbij expliciet het bestaan van de verscheidenheid van ervaringen, belangen en meningen die in elke samenleving aanwezig is, wordt verdisconteerd. Kenmerkend voor wat de horizontale traditie onder politieke ordening verstaat, is dat er eerst geluisterd en overlegd wordt voor er algemeen bindende maatregelen worden genomen. De verscheidenheid van meningen en belangen rond een bepaalde kwestie en eventueel relevante ervaringen moeten daartoe worden gearticuleerd en op enigerlei plaats en tijd - of op meerdere plaatsen - bijeengebracht worden, zodat discussie en overleg over wat met betrekking tot die kwestie het geval is en over de gezamenlijk te volgen koers mogelijk worden. Zoals wij hebben laten zien vindt het bijeenbrengen van meningen en ervaringen niet alleen plaats binnen het kader van staatsrechtelijke instituties maar ook daar buiten. Politiek wordt op vele plaatsen bedreven, door verschillende maatschappelijke actoren, al dan niet in georganiseerd verband en op de meest uiteenlopende wijzen. In de horizontale traditie gaat het om de substantiële legitimiteit (de wat en hoe vraag). De focus ligt op een meer inhoudelijk beoordelingskader.

Vanuit elk van deze twee tradities worden verschillende aspecten van het politieke leven en de politieke praktijk in de schijnwerpers gesteld. In de horizontale traditie gaat het om besturen en is de politicus de bestuurder die nieuwe vormen van collectief handelen ontwikkelt waarin uiteenlopende inzichten worden verzoend. In die traditie richt politiek zich op wikken en wegen en op het kunnen bouwen op de kennis van anderen. In de verticale traditie gaat het om beslissen en is de politicus degene die de knopen doorhakt en wetten uitvaardigt, die macht heeft en daarom moet worden gecontroleerd. Die controle vindt plaats door formeel toezicht en verantwoording te regelen. In de verticale traditie draait politiek om het nemen van legitieme beslissingen. 


\subsubsection{EEN GOED KLIMAAT OM TE LEREN}

Naast het formele, zich naar het staatsrecht richtende discours dat zich op de verticale traditie oriënteert, kent Nederland een lange horizontale politieke traditie. Beide tradities hebben ook hun weerslag op de feitelijke politieke praktijk in ons land. Politiek in Nederland, zo hebben wij laten zien, is een gemengd bedrijf. De participatie van actoren die buiten de statelijke keten van delegatie en verantwoording opereren is een onderscheidend kenmerk van het Nederlandse beleidsbestel.

We hebben aan de hand van voorbeelden laten zien hoe een gemengde praktijk werkt. Deze voorbeelden zijn illustratief voor de vervlechting van de verticale met de horizontale traditie. In deze gemengde praktijk komen de verschillende rollen van politiek en overheid op verschillende manieren tot uitdrukking. De verhouding tussen beide tradities wordt bepaald door de aard van het probleem en de context waarbinnen dat probleem zich afspeelt. Er zijn verschillende varianten die van elkaar verschillen in de mate waarin kaders waarbinnen besluitvorming plaatsvindt verticaal vooraf of achteraf zijn bepaald. Elders heeft de raad bij zijn rapport over het vertrouwen in de buurt (WRR 2005) hier ook aandacht aan besteed. We noemen enkele varianten.

- De horizontale praktijk vindt plaats binnen de kaders die verticaal zijn vastgesteld. Het primaat van de (verticale) politiek staat dan voorop. Deze werkwijze is op tal van terreinen aan de orde. Een voorbeeld is de wijze waarop de nieuwe Vreemdelingenwet van 2000 is voorbereid. Onder leiding van een onafhankelijke voorzitter maar in opdracht van de toenmalige staatssecretaris voor Justitie, is met raadpleging van zoveel mogelijk belanghebbende partijen de nieuwe Vreemdelingenwet tot stand gekomen. In samenspraak met anderen is gewerkt aan afweging en oordeelsvorming. Bovendien is getracht de uitvoeringspraktijk in te brengen in het proces van voorbereiding van wetgeving.

- In andere gevallen speelt de horizontale traditie een eigenstandige rol naast de verticale traditie. Het voorbeeld van de euthanasie laat zien hoe de direct betrokken partijen via beraadslagingen en afwegingen die zich onder meer in de rechtszaal hebben afgespeeld een code hebben ontwikkeld voor de euthanasiepraktijk.

- Zoals in het geval van de prenatale screening en de euthanasie bleek kan het werk buiten de formele politiek de basis leggen voor latere wetgeving. In dit verband kan de ervaring met het overleg tussen belanghebbenden zoals in de SER worden gezien als een geïnstitutionaliseerde manier om andere partijen een voorbereidende rol te geven in wat later eventueel door de politiek gelegitimeerd kan worden.

- In sommige gevallen kan de politiek ook beslissen om zich afzijdig te houden. In het geval van het stakingsrecht heeft de regering besloten zich niet als besluitvormer op te werpen. Behalve een keuze voor afzijdigheid kan ook sprake zijn van bewust beleid om bepaalde kwesties niet (meer) te definiëren als een overheidsverantwoordelijkheid. 
Binnen deze varianten is, door tijd te nemen, ervaringen te articuleren en overleg te voeren, gaandeweg duidelijk geworden wat in het geding was en van wie, waarover, wat voor soort beslissing mag worden verwacht. Tal van actoren hebben daaraan een bijdrage geleverd. Soms vindt dat plaats in geïnstitutionaliseerd verband, maar de praktijk laat ook zien dat steeds vaker afzonderlijke instellingen en bedrijven en/of groepen burgers een belangrijke rol spelen. Verhoeven (2006) analyseert voorbeelden van betrokkenheid en inbreng van burgers en noemt dit alledaags politiek burgerschap. Alledaags heeft daarbij betrekking op het feit dat de kwesties waar het om gaat zich afspelen in de dagelijkse leefwereld van betrokkenen. Met de toevoeging 'politiek' wordt gewezen op het feit dat burgers met hun inbreng en activiteiten de politieke arena betreden. In de eerdere adviezen van de raad Bewijzen van goede dienstverlening (2004) en Vertrouwen in de buurt (2005) zijn veel voorbeelden te vinden van gemengde praktijken. Het proces van afweging en besluitvorming heeft zich niet zonder meer afgespeeld binnen kaders die door regering en parlement werden gesteld. Ook blijken regering en parlement niet te allen tijde de centrale en boven de andere partijen verheven besluitvoorbereidende en besluitvormende actoren te zijn. Eerder is van een collectieve zoektocht sprake naar de kaders waarbinnen over een kwestie beslist zou kunnen worden.

Dit grote repertoire aan mogelijkheden om problemen op te lossen is gunstig voor leren. In gemengde praktijken kan het voorkomen dat verhoudingen diffuus zijn, dat de besluitvormingsprocessen niet zo overzichtelijk zijn, dat tijdens de rit de probleemdefinities veranderen en dat meerdere partijen in wisselende samenstelling bij het totale proces worden betrokken. Maar juist dan is er ruimte voor variatie, voor een situationele benadering met op maat gesneden aanpak, voor lokale aanpassingen, voor het leggen van contacten die inhoudelijk in plaats van formeel-procedureel zijn geïnspireerd. Naast de eerste-orde-leerprocessen, waarbij het erom gaat middelen efficiënt af te stemmen op doelen, bieden gemengde praktijken ook ruimte voor hogere-orde-leerprocessen, waarin doelen (en daarbij behorende middelen) worden onderworpen aan processen van herijking. Het zijn juist deze hogere-orde-leerprocessen die ingezet moeten worden bij hardnekkige problemen. Juist dan is het nodig ruimte te maken voor uiteenlopende normatieve perspectieven zonder deze meteen 'dicht te timmeren' en zijn aandacht en tijd voor analyse en kennisverzameling essentieel om tot inhoudelijke afweging en beoordeling te komen. Bij dit repertoire hoort overigens het belang van het leerproces zelf. Van belang is niet alleen dat er oog en oor is voor de kwaliteit van wat zich buiten de geijkte politieke en bestuurlijke instituties afspeelt, maar ook dat er condities worden gecreëerd voor evaluatie en vormen van feedback en dat de terugkoppeling van resultaten ook daadwerkelijk wordt gebruikt om het beter te doen. Het gaat hierbij om twee soorten leereffecten (Sabel 2004): allereerst kan er intern geleerd worden door ingezet beleid goed te monitoren. Er kan ook extern geleerd worden door ervaringen en evaluaties met anderen te delen dan wel in te zetten in andere contexten. 


\subsubsection{MISKENNING GEMENGDE PRAKTIJK: VERTICALE TRADITIE DE MEETLAT}

In het praten over politiek en het beoordelen van het politieke handelen is op dit moment de verticale traditie de meetlat. De gemengde praktijk wordt eerder als probleem dan als kans gezien. Niet de rijkdom aan mogelijkheden om kennis uit te wisselen en ervaringen te delen, maar het feit dat beslissingen onvoldoende traceerbaar en controleerbaar zouden zijn, staat in de beoordeling centraal. De kans bestaat dat met deze beoordeling 'het kind met het badwater wordt weggegooid'. Terecht kan kritiek geleverd worden op een gemengde praktijk van probleemoplossing in gesloten institutionele circuits met intermediaire organisaties en koepels van belangengroepen. Daarbinnen ontbreekt vaak evenzeer een onderzoekende en zelfkritische houding. Bovendien bestaat het risico dat nieuwe belangen, die ontstaan rond ongetemde problemen, onvoldoende aan bod komen door de dominantie van reeds bestaande, helder geformuleerde en goed georganiseerde standpunten. We hebben echter laten zien dat de gemengde praktijk, mits de processen open en toegankelijk zijn voor verschillende actoren, juist meerwaarde heeft en goede voorwaarden biedt om complexe maatschappelijke thema's te adresseren. Juist bij ongetemde problemen is het nodig om gebruik te maken van een combinatie van kennis en ervaring die zowel binnen het 'klassieke' terrein van politiek en overheid beschikbaar is als daarbuiten.

Door de dominantie van de verticale traditie in het oordelen over de politiek ontstaat een vertekend beeld. De mogelijkheden van het vervlechten van horizontale en verticale praktijken worden onvoldoende in de beoordeling betrokken. Dit vertekende beeld werkt door in de wijze waarop de ambtenaar wordt gepositioneerd, in de vele reorganisaties van de rijksdienst en in het functioneren van de politiek. Wat betreft de rol en positie van de (hoge) ambtenaar doet zich dan ook een paradoxale situatie voor. Aan de ene kant is het belang van zijn rol als expert en adviseur toegenomen. De complexiteit van de maatschappelijke verhoudingen en de aard van de problemen die uiteindelijk bij de overheid terechtkomen, hebben geleid tot een grote mate van inhoudelijke professionalisering van ambtenaren (Jeker 2005). In de vele voorbeelden uit de gemengde praktijk zien we de ambtenaar als inhoudelijk adviseur ook steeds terugkeren. Mertens (1996) spreekt over 'beleidsadviseurs in vaste dienst'. Zij adviseren over inhoud en richting van beleid en doen dat met kennis van zaken en vanuit een eigen positie. Zij leveren een inhoudelijke bijdrage aan het proces van beleidsvorming. Aan de andere kant is de beoordeling van het werk van de (hoge) ambtenaar voornamelijk gebaseerd op zijn vermogen om processen van besluitvorming goed te managen. Hij is verantwoordelijk voor efficiënte besluitvorming met inachtneming van de procedurele vereisten, en draagt zorg voor een goede fasering in de tijd, afstemming met andere departementen en weet op het juiste moment zaken te agenderen die voor het politieke optreden van 'zijn' minister van belang zijn.

Voor het huidig functioneren van de ambtenaar betekent deze situatie dat, terwijl zijn inhoudelijke inbreng meer dan ooit gewenst is, hij vooral wordt aangesproken op relatieflege procesexpertise. De inhoudelijke expertise is vooral 'coulissen- 
werk', het managen van processen daarentegen wordt veelal als het 'echte werk' gezien. Deze voorkeur voor de rol van procesmanager situeren wij in de verticale traditie van het functioneren van politiek en overheid. Het is de moderne variant van het klassiek weberiaans model van de ambtenaar, waarbij de neutraliteit van de ambtenaar, de strikte scheiding tussen politiek en apparaat en de noodzakelijke afstand tussen ambtelijke ondersteuning en het politieke bedrijf centraal staan.

De voorkeur voor procesmanagement is ook steeds meer de feitelijke praktijk. Op nationaal niveau zou een roulatiesysteem in de hogere regionen van het ambtelijk personeel moeten bijdragen aan een esprit de corps en een body of knowledge op het niveau van de rijksdienst als geheel. Op deze manier leren ambtenaren de andere departementen kennen en kan verkokering worden tegengegaan. Ambtenaren vanaf een bepaalde schaal zijn dan niet meer in dienst van één ministerie of één minister maar in dienst van het rijk. De voordelen van het roulatiesysteem - het voorkomen dat ambtenaren te zeer vereenzelvigd raken met een dossier of directoraat en dat ministers en staatssecretarissen partijpolitieke benoemingen doorvoeren - dienen echter afgezet te worden tegen de mogelijke nadelen. Een van de risico's van de gevolgde werkwijze is dat de inhoudelijke kennis van een beleidsterrein minder relevant en gewaardeerd wordt, en uiteindelijk ook minder beschikbaar is. Gaandeweg worden in de carrousel van functies de procescompetenties belangrijker en raken de inhoudelijke kennis, ervaring en expertise op de achtergrond.

Een soortgelijke conclusie kan worden getrokken ten aanzien van de vele voorstellen ter verbetering van het functioneren van de rijksdienst. De meerderheid van de voorstellen is gericht op een verbetering van de procedures in de keten van toezicht en verantwoording. Ook zijn er vele voorstellen gedaan voor meer coördinatie tussen de departementen (ontkokering) en voor een verbetering van de relatie tussen beleid en uitvoering. In feite zijn veel van de reorganisatievoorstellen te beschouwen als een poging om de gegroeide diffuse gemengde praktijken te ontwarren en te vervangen door heldere lijnen met duidelijk afgebakende bevoegdheden en verantwoordelijkheden. Wederom is de verticale traditie het uitgangspunt en wordt vooral gewerkt aan het vergroten van het vermogen van politiek en overheid om te beslissen. Het vermogen om met beleid te wikken en te wegen en vervolgens tot een passende beoordeling en afweging te komen is hiermee niet altijd gediend.

In het WRR-rapport Bewijzen van goede dienstverlening (2004) zijn we ingegaan op de ervaring dat meer transparantie en verantwoording uiteindelijk schadelijk zijn voor het noodzakelijke vertrouwen in de kwaliteit van de dienstverlening. Iets dergelijks geldt voor het aanzien en het functioneren van de politiek. De Beus (2006) wees recentelijk op de negatieve gevolgen van de overmatige waarde die in de parlementaire en bestuurlijke besluitvorming aan transparantie wordt gehecht. Hij betoogt dat politici zich op vele manieren aanpassen aan de nieuwe eisen van transparantie. Veel van die manieren kunnen schadelijk zijn voor de democratie. Hij noemt onder meer het mijden van doelen en inzetten op regels 
en procedures. Politiek bedrijven kan dan versmald raken tot een discussie over verschillende uitvoeringstrajecten. De noodzakelijke ruimte voor inhoudelijke en normatieve afwegingen wordt gemeden.

\section{$5 \cdot 3$ LEERVERMOGEN ONDER DRUK}

Een eenzijdige nadruk op de verticale traditie als meetlat voor goede politiek brengt een aantal risico's met zich mee. Het leervermogen van overheid en politiek komt steeds meer onder druk te staan. Er is weinig ruimte voor het ter discussie stellen van bestaande kaders en voor het reflecteren op de assumpties die aan die kaders ten grondslag liggen. Een overheid die leert kan op basis van opgedane en verwerkte ervaringen problemen waarvoor zij zich gesteld ziet anders (en beter) aanpakken dan voorheen. We noemen vijf risico's.

\section{Bestuurscentrisme}

Het eerste risico is dat eenzijdig binnen de gebaande bestuurlijke paden wordt gedacht en gewerkt zonder oog en oor voor inbreng van andere partijen en zonder discussie over de bestaande bestuurlijke principes. Oplossingen voor problemen, handelingsalternatieven worden primair gezocht binnen de bestaande definitie van de situatie. Die definitie staat niet ter discussie en behoeft hooguit adstructie. Voor zover verbeteringen nodig zijn, worden die gevonden in het versterken van het primaat van de politiek, het verbeteren van de keten van toezicht en verantwoording, het vergroten van de transparantie en het verder verfijnen van het systeem van verdeling van bevoegdheden en verantwoordelijkheden. Deze manier van denken en doen laat zich illustreren aan de hand van de wijze waarop wordt geoordeeld over en gewerkt met de verschillende bestuurslagen. De verhouding tussen rijk en gemeente wordt in hoofdzaak in termen van beleid en uitvoering (Peters 2006) geduid. Het gemeentelijk niveau is niet meer en niet minder dan een uitvoeringsruimte van nationaal beleid. Hooguit is er discussie over de grenzen aan die ruimte.

Het gegeven dat het gemeentelijk beleid een praktijk sui generis voortbrengt die ook benut kan worden op een ander bestuurlijk niveau, wordt niet of nauwelijks onderkend. Dat wekt verbazing. Er zijn talloze voorbeelden te noemen van initiatieven die op het gemeentelijke niveau zelf ontstaan en inzichten bieden in de wijze waarop ingewikkelde maatschappelijke vraagstukken kunnen worden aangepakt. Op het niveau van de gemeente is uiteraard ook sprake van een rijke gemengde praktijk waarbij burgers in samenspraak met overheden tot oplossingen komen. Maar er is meer. Vindingrijkheid bij het oplossen van maatschappelijke vraagstukken is niet alleen te vinden op het lokale bestuurlijke niveau, maar ook op het lokale functionele niveau. We hebben reeds eerder laten zien (WRR $2004 \mathrm{en}$ 2005) dat verschillende sectoren elkaar weten te vinden (bijvoorbeeld onderwijs en arbeid, wonen en zorg, en welzijn en politie) om tot nieuwe oplossingen te komen. Het is opmerkelijk dat deze voorbeelden en initiatieven vooral in termen van uitvoering en specifieke voorbeelden worden beoordeeld, en veel minder als een les en een ervaring die ook op nationaal niveau kan worden ingezet. 
Gemengde praktijken zijn niet nieuw. Anders dan vaak wordt gesuggereerd is er van oudsher sprake van politieke bedrijvigheid op verschillende plaatsen (Dijstelbloem en Meurs 2004). Er zijn als het ware verschillende arena's waar politiek wordt bedreven, die zich door de tijd heen verschillend tot elkaar verhouden, al naar gelang de kwestie die in het geding is. Op dit moment wordt veel gesproken en geschreven over een proliferatie van politiek naar professionele arena's en naar civil society-organisaties/bewegingen die lobbyen voor een bepaald deelbelang (Bovens 2005). In het debat over de verbetering van het functioneren van politiek en overheid wordt deze proliferatie nauwelijks in positieve termen geduid, bijvoorbeeld als een toename van mogelijkheden deskundig advies in te winnen of kennis te nemen van normatieve standpunten. Veeleer is er aandacht voor het democratisch tekort en worden voorstellen gedaan om dit tekort op te heffen door vormen van toezicht en verantwoording te introduceren die juist de positieve bijdrage van deze partijen aan het oplossen van hardnekkige problemen ondermijnt en zelfs tenietdoet.

Een ander voorbeeld van een eenzijdige interne gerichtheid op beslissen op het nationale niveau is ook merkbaar in het debat over 'Europa'. Het is op z'n minst opmerkelijk dat in vrijwel alle voorstellen voor bestuurlijke vernieuwing Europa als een belangrijk motief wordt genoemd voor de noodzaak van verandering. Echter, in de uitwerking blijkt Europa in de meeste gevallen niet meer dan een contextvariabele te zijn. Een fundamentele herijking van het functioneren van politiek en overheid in het licht van Europa vindt niet plaats. De WRR zal in een apart rapport over Nederland in Europa, nader op dit vraagstuk in gaan.

\section{Dominantie van procesdenken}

Een tweede risico is dat politiek en overheid zich steeds meer gaan richten op procedures en regels en op het beheren en beheersen van beslissingsprocessen. De bestuurlijke procesoriëntatie wint het van de maatschappelijke probleemoriëntatie. Dat geldt niet alleen voor het functioneren van de ambtenaar, maar ook voor het functioneren van de politiek en voor de relatie tussen beide. De kritiek op het functioneren van politiek en overheid en het afnemend vertrouwen van burgers worden beantwoord door het tonen van meer daadkracht, het doen van beloftes en het herbevestigen van het primaat van de politiek. De kritiek wordt aldus niet via een inhoudelijke lijn opgepakt maar via een procedurele lijn. Ook politici gaan letten op de procedures, hun feitelijke rol wordt veel meer die van controleur dan van initiator van beleid.

We hebben reeds aangegeven dat het inhoudelijk werk van de (hoge) ambtenaar als beleidsadviseur, steeds meer in het gedrang komt door de grote nadruk op de processturing en op de procedurele zorgvuldigheid. Ook mede daardoor verdwijnt de inhoudelijke expertise van de ambtenaar (Raad van State 2006). De relatie tussen politiek en ambtelijk apparaat wordt primair in positie- en procestermen omschreven en beoordeeld. De ambtenaar staat ten dienste van het politieke proces en is uitvoerder van politieke besluiten. Afwijkingen hiervan, bijvoorbeeld daar waar het beleid in belangrijke mate door ambtenaren wordt 
bepaald en gevoed, zijn dan problematisch. Een minister die dit laat gebeuren wordt in zo'n situatie meestal als 'zwak' gekwalificeerd. De vraag is echter of die kwalificatie in alle gevallen terecht is. Wanneer gewerkt wordt vanuit een meer horizontale traditie is het juist belangrijk dat een minister actief gebruik maakt van de kennis en ervaring die in zijn nabijheid beschikbaar is.

De eenzijdige oriëntatie op processen heeft ook tot gevolg dat maatschappelijke vragen en kwesties eerder in relationele en ruimtelijke termen worden geduid dan inhoudelijk onderzocht. Het duidelijkste voorbeeld hiervan is het denken en praten in termen van 'kloven' en 'afstanden' (Noordegraaf 2006). Zo ongeveer dagelijks wordt herhaald dat er sprake is van een kloof tussen burger en politiek, dat de afstand tussen ambtenaren en werkveld te groot is of dat professionals en managers elkaar niet begrijpen. De oplossingen worden bepaald door de termen waarin het probleem is gedefinieerd: de kloof dichten, de afstand verkleinen. Dit alles om vervolgens beter te kunnen sturen en beslissen, om beter te kunnen voldoen aan de wensen van de burgers.

In onze redenering is niet zozeer de kloof het probleem als wel het feit dat er in die termen over gesproken wordt, zonder dat er een verkenning plaats vindt van wat er inhoudelijk aan de hand is. Verondersteld wordt dat verschillende werelden bij elkaar gebracht moeten worden en dat die nabijheid beter is voor het functioneren van overheid en politiek. Verondersteld wordt dat door beter kennen beter bestuur en beleid wordt gerealiseerd (Noordegraaf 2006). Het is echter een miskenning van het feit dat kennis en ervaring op verschillende plaatsen worden geproduceerd. Het willen overbruggen van de zogenaamde kloof en het beter willen begrijpen - in casu beheersen - van verschillende werelden, kan juist leiden tot een ongewenste vertaling van de ene wereld naar de andere. Zo kan het gebeuren dat het werk van de politieman steeds meer in termen van afrekenbare eenheden wordt gedefinieerd, waardoor zijn rol in veiligheidsnetwerken in het gedrang komt (Van Stokkom en Terpstra 2006), en dat een incident door de politiek wordt gebruikt om een oordeel te geven over het functioneren van de totale sector. De juist zo noodzakelijke stap van afwegen en beoordelen en daarvoor de tijd nemen blijft achterwege. Die mediërende rol is echter van vitaal belang bij vraagstukken waar sprake is van een diversiteit van meningen en oplossingen.

\section{Dilemma's omzeild}

Een derde risico is dat wordt afgezien van een verdere investering in het beproeven en verbeteren van een praktijk waarin verticale en horizontale tradities worden gecombineerd. Wij hebben in de analyse laten zien dat deze combinatie niet zonder problemen is. De verticale traditie is hoofdzakelijk gericht op het behouden en versterken van de democratische legitimiteit, onder meer door heldere scheiding van bevoegdheden. De noodzakelijke inbreng van andere deskundigen die buiten de politieke arena functioneren wordt veronachtzaamd. Andersom mag niet ontkend worden dat vanuit de horizontale traditie onvoldoende antwoord wordt gegeven op de vraag naar de legitimiteit van besluiten. Ook kunnen in de horizontale traditie betrokken actoren elkaar in een verlam- 
mende greep houden en ontbreekt soms een derde partij om een dergelijke impasse te doorbreken.

Beide tradities hebben hun gebreken, maar pas als de gemengde praktijken worden beproefd is het mogelijk te onderzoeken hoe die van een antwoord kunnen worden voorzien. Het horizontale principe dat in redelijkheid met inbreng van relevante publieken bestuurd moet worden en het verticale beginsel dat de legitimiteit van overheidsbeslissingen uiteindelijk bij de kiezer berust, laten zich niet makkelijk verenigen. Op verschillende momenten en op uiteenlopende manieren kunnen spanningen ontstaan: hoe kan bijvoorbeeld de democratische legitimiteit worden geborgd en breder de algemene rechtstatelijke beginselen, terwijl tegelijkertijd ruimte wordt geboden voor variatie, voor de inbreng van kennis en ervaring die niet zonder meer democratisch gelegitimeerd is?

Dat dit geen makkelijke opgave is, wordt goed geillustreerd door Hertogh (2006). In zijn analyse van het actieprogramma 'Rotterdam zet door' geeft hij aan hoe aan de ene kant een onconventionele manier van optreden heeft geleid tot onconventionele maatregelen die ook op steun van het kabinet hebben kunnen rekenen, terwijl aan de andere kant ook veel vraagtekens geplaatst kunnen worden bij de bestuurlijke legitimiteit van het openbaar bestuur. Wanneer lastige problemen vragen om een lokale aanpak en maatwerk, dan kan dat ingrijpende gevolgen hebben voor de invulling van het gelijkheidsbeginsel. Hier ligt bij uitstek een rol voor de politiek: niet de spanning negeren en de afweging tussen maatwerk en gelijkheid uit de weg gaan, maar een benadering nastreven waarbij per situatie naar een passende invulling van het gelijkheidsbeginsel wordt gezocht. Als gewerkt wordt met experimenten, zoals ook wij voorstaan, is het van belang aandacht te hebben voor de rechtstatelijke ruimte waarbinnen die experimenten kunnen plaatsvinden.

Het voorbeeld van het actieprogramma 'Rotterdam zet door' laat in feite twee kanten van de medaille zien. Aan de ene kant het introduceren van nieuw beleid op basis van lokale kennis en ervaring om een bepaald maatschappelijke probleem aan te pakken, en deze zelfs wettelijk verankeren. Aan de andere kant het nog onvoldoende ijken, herijken en zorgvuldig afwegen van de gevolgen die dit heeft voor het gelijkheidsbeginsel. Er is in de Tweede Kamer en ook daarbuiten uiteraard uitgebreid gesproken over de gevolgen die de Rotterdamwet (vgl. hoofdstuk 4) zou kunnen hebben voor het gelijkheidsbeginsel. Het is jammer dat deze wet niet expliciet als experiment is ingericht en dat niet de politieke en organisatorische maatregelen genomen zijn om van de ervaringen die in Rotterdam met de wet worden opgedaan systematisch te leren. Als dat wel was gebeurd, had de politiek zowel lokaal als nationaal kunnen leren van de ervaringen die gaandeweg worden opgedaan. Het ziet er naar uit dat de wens om een bepaald probleem daadkrachtig en doortastend aan te pakken de overhand heeft gekregen. Een - naar ons oordeel noodzakelijke - inhoudelijke afweging op basis van opgedane ervaringen zodat opnieuw kan worden nagedacht over een (alternatieve) invulling van het gelijkheidsbeginsel, is niet expliciet afgesproken, en juist daarin ligt de betekenis van politiek. 


\section{Bureaucratisering van ervaring}

Een vierde risico betreft de vervorming van ervaringen tot informatie die in een bureaucratisch systeem kan worden verwerkt. In de verticale traditie is een vitale plaats ingeruimd voor processen van informatieverzameling en verantwoording. Als het bevoegd gezag ruimte vrijlaat aan anderen om de publieke zaak te dienen, dient dat dan echter wel zo te geschieden dat op een eenduidige manier kan worden gerapporteerd en verantwoording afgelegd. Het effect is in het jaarverslag van 2003 van de Raad van State verambtelijking van de publieke ruimte genoemd. Verschillen, conflicten en uiteenlopende belangen worden beheerst door meer procedures op te stellen en meer controleurs te benoemen. Eerder hebben wij op de gevaren gewezen van een eenzijdige nadruk op registratie en meetbare verantwoordingsinformatie (WRR 2004). Niet wat men echt wil weten wordt dan opgeschreven, maar datgene wat op het formulier past of gemeten kan worden. Het gebruik van informatietechnologie versterkt deze oriëntatie op procedures en systemen (Frissen 1996; Zuurmond 1994).

Drenth (2006) merkt op dat het bezwaar tegen wat zij noemt de 'cerebralisering' van taal en tekst niet alleen ligt in de ontoegankelijkheid en uitsluiting die daarvan het gevolg kunnen zijn. Zij wijst ook op het feit dat teksten als het ware losgezongen raken van betekenis en inhoud. Deze ontwikkeling treft overigens niet alleen de ambtenaren en politici die met deze teksten moeten werken. Op het moment dat, in lijn met de verticale traditie, ruimte aan anderen wordt gegeven en bevoegdheden worden overgedragen, neemt de eis van verantwoording navenant toe. Niet alleen professionals moeten van alles registreren maar ook burgers worden behalve 'object' ook subject van dossiervorming. 'De verantwoordelijke burger wordt ook een verantwoordende burger' (Drenth 2006). Van burgers wordt gevraagd dat zij hun ervaringen, de kwestie die zij aan de orde willen stellen, omzetten in codes die passen bij het bureaucratisch proza. Zo bezien wordt hier de kloof 'gedicht' door een verdere bureaucratisering van de wijze waarop over eigen ervaringen en incidenten wordt gerapporteerd.

De noodzaak van wat Drenth (2006) een geëngageerde bemiddeling noemt en door Noordegraaf (2006) als de tussenruimte wordt omschreven, verdwijnt naar de achtergrond als het systeem het wint van de ervaring, of van het incident. Het interpreteren en contextualiseren van de ervaring vindt niet meer plaats, een zoektocht naar andere vormen van verantwoording die dichter bij de ervaring zelf liggen, blijft achterwege. Vanuit de verticale traditie is de veel bekritiseerde incidentenpolitiek een manier om kwesties of misstanden aan de kaak te stellen en maatregelen te eisen dan wel te treffen. De specificiteit van de ervaring gaat dan snel verloren, de procedure vraagt om generieke maatregelen en incidenten zijn dan niet meer dan de aangevers van iets algemeners wat al bekend is. Daarmee gaat de betekenis van het incident en de ervaring die in dat incident is opgeslagen, verloren. Evenzeer verdwijnt dan de functie van politiek om te bemiddelen tussen abstractie en detail, tussen incident en generieke maatregelen. 


\section{Eenzijdige politisering van informatie}

Ten slotte is er het risico dat informatie eenzijdig wordt ingezet om de controletaak van de politiek uit te oefenen. Veelal wordt op voorhand vastgesteld dat politiek en overheid niet kunnen leren. Immers, dat leren moet plaatsvinden binnen rechtsstatelijke en democratische kaders. De overheidsorganisatie wordt hiërarchisch bestuurd met een keten van delegatie en verantwoording. Deze twee kenmerken zouden blokkades voor het leren vormen. Leren impliceert een kritische maar ook kwetsbare opstelling, de mogelijkheid om fouten te maken, het werken met verschillende probleemdefinities, discretionaire ruimte voor ambtenaren en het werken met ongelijke uitkomsten. Het impliceert ook dat kennis, informatie en ervaring voor verschillende doeleinden worden ingezet, en dat er binnen de politiek-ambtelijke verhoudingen gelegenheid is problemen inhoudelijk en normatief te onderzoeken en te duiden. Dit alles kan op gespannen voet komen te staan met grondwettelijke principes van gelijkheid en toegankelijkheid, met het beginsel van de neutraliteit van de ambtenaar en met de klassieke taakverdeling tussen parlement, regering en ambtelijk apparaat.

Voor zover er sprake is van leerprocessen, zijn deze dan ook hoofdzakelijk gericht op het doorvoeren van aanpassingen binnen bestaande kaders. Leren krijgt de vorm van controleren. Een goede illustratie van deze omslag is het gebruik van de parlementaire enquêtes en de parlementaire onderzoeken ('t Hart 2001). In de negentiende eeuw heeft de Kamer, in de sfeer van haar medewetgevende taak, een aantal keren gebruik gemaakt van het enquêterecht. Het onderzoek was toen sterk op de toekomst gericht en het ging de Kamer erom de regering te bewegen om bepaalde initiatieven te nemen (Visscher 1999). Bij de recente enquêtes ging het om een heel ander type onderzoek. Ook al is het niet gezegd dat de uitkomsten geen lessen voor de toekomst hebben opgeleverd, de onderzoeken stonden de facto primair in het teken van de controle op het gevoerde beleid en waren in die zin op het verleden gericht. Hoofddoel was vast te stellen wat de rol van de overheid was geweest in complexe en omvangrijke besluitvormingsprocessen en wie daar uiteindelijk de (ministeriële) verantwoordelijkheid voor droeg. In elk van de rapporten was er kritiek op het gebrekkig en zelfs onjuist informeren van de Kamer (Van Thijn en Cardoso Ribeiro 2004). Omdat fouten telkens aanleiding zijn voor parlementaire enquêtes, wekt elk onderzoek tegenwoordig bij voorbaat de suggestie van politiek en ambtelijk onvermogen.

In de Kamer wordt ook gebruik gemaakt van het parlementair onderzoek, een minder zware interventie dan de enquête, maar naar zijn vorm ook gericht op het verleden en op de vraag wat de betrokkenheid van de overheid is geweest bij beleid. Ook hier ligt de nadruk op de wie-vraag en minder op de wat- en hoevragen. Een uitzondering daarop was het toekomstgerichte onderzoek van de Klimaatcommissie uit 1996 dat zich richtte op bijeenbrengen en openbaar maken van (wetenschappelijke) kennis over klimaatverandering en het voor een groter publiek inzichtelijk maken van keuzes over mogelijke oplossingen (Muller en Coenen 2002: 28-29). Ook het recente parlementair onderzoek TBS-stelsel onder leiding van A.Visser en het parlementair onderzoek infrastructuurprojecten 
onder leiding van A. Duivesteijn kunnen worden gezien als goede voorbeelden van een onderzoek waarin kennis, afweging en beoordeling de boventoon hebben gevoerd.

Opmerkelijk is dat zowel het onderzoek als de enquête bij uitstek een instrument is dat het mogelijk maakt om vanuit het parlement horizontale politiek te legitimeren. Ze vormen een gezaghebbende manier om meningen, opvattingen, expertise en ervaringen bij elkaar te brengen en te waarborgen dat alle relevante publieken bij de zaak worden betrokken. De horizontale praktijk treedt als het ware binnen de klassieke arena van de democratie en krijgt door die toetreding juist de legitimiteit die zij daarbuiten ontbeert. De versmalling in de richting van controle en toezicht heeft de mogelijkheid om ook daadwerkelijk iets te leren van opgedane ervaringen ondermijnd.

Vanaf 2003 is een nieuwe procedure toegevoegd en wel de derde woensdag van mei (Dag van de Verantwoording) waarin jaarlijks de jaarverslagen van de diverse ministeries aan de Kamer worden aangeboden. Daarbij krijgen de financiële kant en de effectiviteit van het beleid de meeste aandacht. Ook hier zien we dat het om terugkijken gaat, om beoordelen of de ministeries rechtmatig hebben gehandeld. Voor een deel heeft dat te maken met het feit dat de Vвтв behalve een verantwoordingsinstrument ook een begrotingsinstrument is. Dat betekent dat vooraf reeds zeer precies moet worden aangegeven waaraan de jaarlijkse begroting besteed gaat worden. Een inhoudelijk debat met relevante publieken over een beleidsagenda gericht op het leren van ervaringen kan daardoor niet of nauwelijks plaatsvinden. De evaluatie van 2004 stelde dan ook dat de probleemanalyse en de betrokkenheid van de overheid beter onderbouwd moesten worden. Ook werd kritiek geleverd op het slecht leesbare karakter van de rapportage, waaruit nauwelijks was op te maken wat er gedaan is, welk effect en welke lessen daaruit geleerd kunnen worden. Overigens kan ook hier worden opgemerkt dat aanvankelijk het proces waarbij beleidsprioriteiten worden gesteld om vervolgens verantwoording af te leggen over de realisatie ervan, is opgezet als een vorm van leren. Eenmaal gestart blijken het controleren en afrekenen al snel te gaan overheersen.

\subsection{EEN AANVULLEND PERSPECTIEF: LERENDE OVERHEID}

Wij pleiten voor een verandering van het politieke discours waarin de bijdrage van de gemengde praktijk van politiek bedrijven op waarde wordt geschat en waarin de verscheidenheid aan rollen van politiek en overheid wordt erkend. Het kernprobleem van politiek en overheid is naar ons oordeel lang niet altijd een gebrek aan daadkracht en doorzettingsmacht, evenmin is het probleem primair gesitueerd in een te grote afstand tussen burger en politiek. Het probleem is veeleer dat de politiek is ingeklemd geraakt tussen een zeer strakke coalitieagenda, sterk wisselende politieke voorkeuren, een grote nadruk op controle, beheersing en transparantie en een vorm van mediaberichtgeving die incidenten onder het vergrootglas legt. Overheid en politiek worden steeds meer in een keurslijf 
gedrukt waarin het volgen van de procedures, het verscherpen van posities en het meten van prestaties de centrale maatstaven zijn. Dit keurslijf is echter in veel gevallen niet geschikt voor de behandeling van de maatschappelijke thema's waar overheid en politiek mee te maken krijgen. Juist voor de ongetemde problemen die we in dit rapport op de voorgrond zetten, is een aanvullend repertoire nodig. Dat repertoire biedt ruimte om te leren en hoeft in de meeste gevallen niet opnieuw te worden uitgevonden, integendeel. Er kan als het ware geput worden uit bestaande tradities. De voorbeelden van een meer inhoudelijke en probleemgerichte manier van politiek bedrijven zijn beschikbaar en zouden naar het oordeel van de raad meer dan nu gebeurt, benut moeten worden. De politiek kan naast haar controlerende en wetgevende taak veel meer werk maken van haar inspirerende opdracht. Dat wil zeggen het agenderen van maatschappelijke vraagstukken, het uitdagen van de regering om te komen tot nieuwe benaderingen, probleemdefinities en daarbij horende oplossingen. De inhoudelijke expertise van ambtenaren kan beter worden ingezet en ontwikkeld en de politiekambtelijke verhoudingen kunnen op meer realistische en inhoudelijke leest geschoeid worden.

Met ons pleidooi voor een meer inhoudelijke oriëntatie waar leren en experimenteren een belangrijke rol spelen en waar de analyse en oplossing van problemen leidend zijn, kan ook een bijdrage worden geleverd aan het ombuigen van het door velen gesignaleerde afnemend vertrouwen van burgers in het functioneren van politieke instituties. Naar het oordeel van de raad wordt het vertrouwen van de burgers in overheid en politiek juist gevoed door te investeren in een inhoudelijke benadering van ingewikkelde kwesties waarbij ook hun kennis en ervaring een plaats kan krijgen. Dat biedt meer mogelijkheden dan het vrij eenzijdig investeren in de verbetering van procedures, het reorganiseren van departementen en andere veel voorgestelde structuurwijzigingen. Structuurvoorstellen zijn bijna per definitie gericht op stroomlijning en coördinatie van en dus op een betere beheersing en een betere controle. Het risico is groot dat niet het (beleids)probleem zelf centraal wordt gesteld, maar de vorm waarin het gegoten moet worden. Dit risico klemt des te meer wanneer we ons realiseren dat burgers zelf nooit om grootschalige structuurwijzigingen hebben gevraagd (Kennedy 2003 en 2004).

Het is nodig meer ruimte te maken voor een manier van politiek bedrijven die gericht is op het opzoeken van een variëteit aan meningen en ervaringen om van daaruit tot afweging en oordeelsvorming te komen. Dit houdt in dat de arena waarbinnen wordt gewerkt niet strak omlijnd is en dat er afhankelijk van de aard van het probleem verschillende publieken worden betrokken. Er is ruimte voor experimenten en tijdens het spel worden ervaringen uitgewisseld en opvattingen bijgesteld, zonder dat dit steeds met grootschalige politieke veranderingen gepaard hoeft te gaan. Daar hoort bij het inhoudelijk uitzoeken wat rond bepaalde hardnekkige problemen precies in het geding is en wat het object is waarover de politiek zich uiteindelijk dient te buigen. 
Voor alle duidelijkheid, ons pleidooi voor een inhoudelijke benadering en meer mogelijkheden en tijd voor afweging en oordeelsvorming, betekent niet dat wij zonder meer tegen beheersing en controle zouden zijn. Het probleem ontstaat wanneer die oriëntatie op beheersing en controle losgezongen van de inhoud raakt en een doel op zichzelf wordt. Dan worden daadkracht en doorzettingsmacht loze mantra's die de illusie wekken van leiderschap, maar feitelijk verhullen dat de lastige en ambigue inhoudelijke weging en beoordeling van verschillende posities, opvattingen en ervaringen onvoldoende plaatsvindt. Het risico bestaat dat deze inhoudelijke en normatieve 'leegte' tot een uitholling van de politieke praktijk leidt. Voor de geloofwaardigheid van de politiek en de overheid moet dat nu juist worden voorkomen. Ons pleidooi is erop gericht de ingewikkelde en soms zeer lastige opgave van politiek en overheid te erkennen en een handelingspraktijk voor te stellen die met die complexiteit rekening houdt en voorkomt dat er met te simpele oplossingen of eenzijdige structuuraanpassingen wordt gewerkt, die vanwege gebrek aan resultaat vaak ook nog over elkaar heen buitelen.

We hebben laten zien dat er in Nederland veel ervaring is opgedaan met oplossen van problemen door gebruik te maken van ingenieuze combinaties van verticale en horizontale besturingsarrangementen. Deze moeten echter wel worden onderhouden en verbeterd. Wij stellen een agenda voor die gericht is op het onderhouden en verbeteren van die gemengde praktijken. Een agenda die het mogelijk maakt om bij ongetemde problemen daar waar nodig een onderzoeksbenadering te kiezen, ervaringen te bundelen, andere partijen te betrekken en de oplossing op sommige momenten buiten de kaders van overheid en politiek te zoeken. Nederland verkeert in een betere staat dan vaak wordt gedacht. Wel kan er beter gebruik worden gemaakt van de ervaring, kennis die reeds voorhanden is en soms onvoldoende wordt gezien en op waarde geschat. Leiderschap wordt daarbij niet alleen afgemeten aan de mate van daadkracht en beslisvaardigheid. Leiderschap behelst ook het vermogen om juist - daar waar dat nodig is - van direct optreden te kunnen afzien om eerst verschillende posities en opvattingen te wegen en deze vervolgens bij elkaar te brengen in een aanvaarde en aanvaardbare koers.

Met de voorgestelde agenda richten wij ons op de houding en het gedrag van ambtenaren, parlementsleden en regering en op aanvullende manieren om legitimiteit te verwerven. Met deze agenda kan het leervermogen van overheid en politiek worden vergroot. Er komt ruimte vrij om met verschillende werkwijzen te experimenteren en verzamelde informatie aan te wenden voor evaluatie en verbetering van de eigen praktijk. Daar waar nodig en gewenst kunnen alternatieve perspectieven, probleemdefinities en oplossingen worden verkend en toegepast.

\section{Inhoudelijke ambtenaren}

De (hoge) ambtenaren kunnen meer dan nu gebeurt worden aangesproken als inhoudelijk adviseur van de politiek verantwoordelijken. Het is van belang hun 
rol als coproducent van beleid te erkennen en te benutten. Dit zou niet weggezet mogen worden als 'coulissenwerk', want het is een essentieel onderdeel van het ambt. Anders dan in de klassieke versie van de neutrale weberiaanse ambtenaar, pleiten wij voor de ontwikkeling van een ambtelijke professionaliteit waarbij inhoudelijke kennis van zaken centraal staat. Dat betekent kennis van de beleidssectoren waar het departement voor verantwoordelijk is. Het gaat daarbij niet alleen om inhoudelijke kennis van de onderscheiden dossiers en van het feitelijk functioneren van een bepaalde sector, het gaat ook om netwerkkennis. Ambtenaren zullen bij uitstek kunnen en moeten functioneren als verbindingsschakels tussen verschillende experts en belangengroepen om de verspreide kennis bij elkaar te brengen en te kunnen betrekken bij de uiteindelijke afweging (Wallage 2005). Van ambtenaren mag verwacht worden dat zij weten hoe het netwerk op een bepaald beleidsterrein in elkaar zit, welke 'publieken' van belang zijn, waar kenniscoalities zich bevinden en hoe deze kunnen worden ingezet voor de publieke zaak. In dit licht bezien is het activeren van andere arena's waar kennis bijeen wordt gebracht een belangrijke competentie van ambtenaren.

Het verwerven van inhoudelijke kennis en netwerkkennis is een kwestie van lange adem. Het kunnen wegen van de meer normatieve aspecten van ingewikkelde kwesties is dat evenzeer. Tegen deze achtergrond dient een roulatiesysteem onder hoge ambtenaren zoals dat nu functioneert in het kader van de Algemene Bestuursdienst (ABD), kritisch tegen het licht te worden gehouden. Het risico bestaat dat er onbedoeld ongewenste kennisvernietiging plaatsvindt. De noodzakelijke verbinding tussen departementen en het verhinderen dat ambtenaren 'vastroesten' op een plek binnen de rijksoverheid, staan met deze waarschuwing zeker niet ter discussie. We willen vooral de aandacht vestigen op het belang van een goede inzet van de inhoudelijke inbreng en ervaring van ambtenaren. Wat ons betreft kan de nu wel zeer dominante rol van de ambtenaar als procesarchitect meer naar de achtergrond schuiven, ten gunste van een meer inhoudelijke oriëntatie en kennisopbouw.

Een goede inbreng van ambtenaren wordt niet bereikt door de structuur waarbinnen zij werken steeds te veranderen, maar door in te zetten op het functioneren van de ambtenaar zelf en ruimte te bieden voor zijn of haar inhoudelijke inbreng. De ambtenaar mag niet uitsluitend gezien en beoordeeld worden als 'horige' van de minister. Er is waardering nodig voor zijn rol als inhoudelijk adviseur en loyale doch kritische tegenspeler van de politiek verantwoordelijken. De praktijk heeft uitgewezen dat loyaal zijn en kritisch tegenspel bieden goed te combineren zijn en juist het wezenskenmerk moeten vormen van de professionele ambtenaar van deze tijd (Mertens 1996; 't Hart et al. 2002; Jeekel 2005).

Deze meer expliciete - achter de coulissen gebeurt het immers al wel - betrokkenheid van ambtenaren bij de vormgeving en afweging van beleid, vergt ook dat ambtenaren zich daarover verantwoorden in de richting van hun superieuren. Daar past ook bij - een praktijk die nu mondjesmaat wordt beoefend - dat ambtenaren in specifieke situaties met een voorname rol in een bepaald beleidsdossier 
ook zelf Kamerleden gericht informeren. Het spreekt vanzelf dat dit alles altijd zal plaatsvinden onder goedkeuring en verantwoordelijkheid van de minister. Zowel voor Kamerleden als voor ambtenaren geldt dat de onderlinge informatieuitwisseling, het voor elkaar aanspreekbaar zijn, de kwaliteit van het werk ten goede kan komen. Bovendien kan het een deel van het geritualiseerde verkeer tussen politiek en overheid doen verminderen. In het bijzonder kan hier gedacht worden aan de vele Kamervragen die worden gesteld en door ambtenaren moeten worden beantwoord. Hoewel de Kamervraag meerdere doelen dient (Wille 2005) en zelden ten onterecht gesteld wordt (вов 2005), kan een goed werkende democratie met minder toe.

\section{Het parlement: inspirator naast controleur}

Het parlement is bij uitstek de plaats waar weging van argumenten en belangen plaatsvindt, waar de bemiddelende rol van de politiek tot zijn recht kan komen en waar kennis wordt gedeeld en uitgewisseld. Dit betekent uiteraard niet dat de controlerende taak veronachtzaamd moet worden, maar wel dat het parlement meer werk kan maken van zijn andere rollen als (mede) wetgever en volksvertegenwoordiger. Vooral als hardnekkige problemen in het geding zijn is controle niet voldoende en is een inhoudelijke inbreng van belang. Zo bezien zou het parlement een meer inspirerende rol kunnen vervullen door een inhoudelijke inbreng beter voor het voetlicht te brengen en niet vooral de aandacht te richten op de procedurele controle op het doen en laten van de minister. Als het parlement ook een plaats is waar ervaringen bijeengebracht worden, kan het zich niet uitsluitend baseren op verantwoordingsinformatie die langs bureaucratische weg wordt verkregen. Dat geldt tevens voor de informatie over het electoraat die politici via verkiezingen, de media en diverse onderzoeksbureaus bereikt. Ook voor het parlement geldt dat zij eigenstandig andere methoden en kennisbronnen zal moeten aanboren.

Er is van vele kanten een pleidooi gehouden voor de versterking van de onderzoekscapaciteit van de Tweede Kamer. Recentelijk is daarvoor het Onderzoeksen Verificatiebureau in het leven geroepen en is een vijftal permanente economische adviseurs aangetrokken (de Raad van Economisch Adviseurs). In het licht van onze analyse kiezen wij voor een ander accent: het versterken van de onderzoeksmogelijkheden van de Kamerleden zelf, opdat het werk niet wordt 'uitbesteed' aan onderzoekers, maar zij persoonlijk op onderzoek uitgaan. Kamerleden zijn de afgelopen decennia, in een poging zich meer te richten op medebestuur, immers al meer dan genoeg naar binnen gericht gaan werken, en zich gaan oriënteren op de departementen (Wille 2005), zonder dat zij de kennisvoorsprong van ambtenaren overigens hebben kunnen compenseren (Ringeling 2004: 58). Deze ontwikkeling leidde eveneens tot de opkomst van het uit de ambtelijke sfeer afkomstige Kamerlid (Van den Berg en Van den Braak 2004: 77) De bijzondere taak van Kamerleden ligt echter in het articuleren van publieke problemen waarvoor nog geen oplossing voorhanden is, of waar bestaande oplossingen omstreden zijn geraakt of onbedoelde en vervelende bijwerkingen hebben, die via de ambtelijke lijn moeilijk te corrigeren zijn. Deze werkwijze 
wordt natuurlijk her en der reeds gepraktiseerd (voor een interessant voorbeeld zie Dijsselbloem en Kalsbeek 2005), maar kan systematischer en meer navolging krijgen.

Een probleemgerichte benadering, een eigen verkenning van het probleem, van uitvoeringsperikelen en de normatieve keuzes die aan de orde zijn, maakt het mogelijk dat Kamerleden uit de eerste hand de benodigde kennis en ervaring verzamelen. Deze kan vervolgens weer worden ingebracht in het politieke debat en worden besproken met betrokken bewindslieden. De kleine stages en werkbezoeken van parlementsleden zijn uiteraard nuttig maar niet voldoende. Voor een meer gedegen kennisverzameling is nodig dat Kamerleden dichter bij de ervaring zelf komen te staan. Een eigen onderzoek betekent ook het formuleren van een eigen probleemstelling. In veel gevallen zal dat kunnen inhouden dat er over beleidssectoren heen wordt gewerkt met een eigen aanpak en onderzoeksstrategie. Zoals gezegd is in de huidige praktijk van het Kamerwerk deze werkwijze eerder uitzondering dan regel, iets wat je erbij doet als er tijd is. Naar het oordeel van de raad zou het veel meer als een van de kernen van het werk van Kamerleden gedefinieerd kunnen worden.

Net zoals bij de ambtenaren is inhoudelijke kennis en netwerkkennis van belang. Wat dat laatste betreft heeft het parlement nog een extra verantwoordelijkheid: het legitimeren van horizontale politiek. Het parlement zou moeten kunnen beoordelen of alle relevante partijen aan tafel hebben gezeten, of de verschillende meningen en posities voldoende zijn gehoord. Andersom kunnen politici stimuleren dat verschillende onderwerpen ook daadwerkelijk publiek worden: dat ze besproken worden, dat relevante publieken bij de zaak worden betrokken. Het voorbeeld van de parlementaire enquête en het parlementair onderzoek laat zien dat er uitstekende en niet mis te verstane instrumenten - mits goed aangewend beschikbaar zijn om deze rol te vervullen.

In hun vertegenwoordigende rol hebben parlementsleden vooral de taak om de verscheidenheid aan meningen en opinies bijeen te brengen en te wegen. Dat is iets heel anders dan - wat nu vaak gebeurt - het weerspiegelen van die meningen. De interpretatie en weging van verschillende meningen behoren tot de kern van de vertegenwoordigende opdracht van het parlement. Bij de selectie van Kamerleden door politieke partijen zou daarom, zeker nu politieke partijen in een postverzuild tijdperk grotendeels op zichzelf zijn komen te staan, behalve aan de onderzoekende houding van de kandidaat ook aandacht gegeven moeten worden aan het vermogen zelfstandig maatschappelijke ontwikkelingen te onderkennen en te agenderen.

In het huidige discours wordt veel aandacht besteed aan de versterking van de directe democratie: het debat over de referenda is daarvan een goed voorbeeld, maar ook de kritiek op de te grote kloof tussen burger en politiek. Naar het oordeel van de raad is het van groot belang te blijven investeren in de kwaliteit van de indirecte democratie. Het parlement is zoals gezegd veel meer dan een 
forum waar representatie van uitgesproken meningen van kiezers aan de orde is. In de democratie is een vitale rol weggelegd voor het parlement om juist ook het onrepresenteerbare te representeren, om geluiden die onvoldoende worden gehoord ook in te brengen, om te onderzoeken welke zaken zijn blijven liggen en ook om daar waar nodig de stem van assertieve burgers en goed georganiseerde belangengroepen te dempen. Deze opdracht kost tijd en vraagt niet alleen het leren van de mores van de Kamer, maar vooral ook het leren hoe een bepaald beleidsterrein in elkaar zit, welke publieken relevant zijn en meer en minder worden gehoord. Het is belangrijk om kennis op te bouwen en deze ook in te zetten om de meer omstreden en moeilijk te representeren aspecten van een bepaalde kwestie voor het voetlicht te brengen. Dat vergt een meer inhoudelijke argumentatie die alleen verkregen wordt door kennis en ervaring.

Het werken vanuit een meer inhoudelijke oriëntatie kan er ook toe leiden dat meer dan nu gebeurt in het proces van wetgeving een pas op de plaats wordt gemaakt. Te zeer is de aandacht nu gericht op het binnenhalen van de eigen 'punten'. Het zicht op het totaal raakt achter de horizon. Het zou de inhoudelijke kwaliteit van het politieke werk ten goede komen als er ook momenten van bezinning worden ingelast, als een proces van beraadslaging kan worden stopgezet om te kunnen terugkeren naar de inhoud en naar een oordeel over de effecten van alle amendementen op de consistentie en uitvoerbaarheid van de wet als geheel.

\section{Regeren met een inhoudelijk programma}

Een overheid die werkt vanuit een inhoudelijke oriëntatie is niet gebaat bij een gesloten contract waarin van tevoren wordt vastgelegd wat de exacte inspanningen en wat de precieze resultaten zullen zijn. Het verdient aanbeveling bij de vorming van een nieuwe regering te investeren in een regeerprogramma waarin - met name waar het ongetemde problemen betreft - op hoofdlijnen de inhoudelijke prioriteiten worden bepaald. Gaande de rit kan gebruik worden gemaakt van opgedane ervaringen om te leren en tot bijstellingen te komen. Het programma kan afhankelijk van die ervaring van karakter veranderen. Die openheid biedt mogelijkheden om hardnekkige problemen met een open vizier tegemoet te treden. In een gesloten regeerakkoord is er een grote gerichtheid op voorspelbare uitkomsten en harde en controleerbare afspraken. Voor sommige dossiers is dit een zeer gewenste strategie, maar voor andere thema's die omstreden en ingewikkeld zijn, verdient een programmatische benadering met een meer open einde de voorkeur. Juist bij ongetemde problemen moeten bewindslieden - zelfs als ze op een meerderheid kunnen rekenen - open blijven voor de inbreng van de oppositie en van de kleine partijen. Eenzijdige machtspolitiek kan onnodige schade aanrichten en kan de bereidheid van deze partijen verkleinen om ook over andere ongetemde uitdagingen constructief mee te denken.

Een programmatische werkwijze heeft bovendien een bijkomend voordeel dat bewindspersonen investeren in een goede probleemdefinitie en in een verkenning van elkaars meningen en overtuigingen zonder dat meteen onderhandeld hoeft te worden over een van tevoren bepaald resultaat. 
We hebben laten zien dat kennis en ervaring verspreid zijn onder vele actoren en publieken. De feitelijke praktijk is dat zij ook een inbreng hebben in de bepaling van de beleidsagenda en in het aandragen van aanvaardbare en haalbare oplossingen. Deze inbreng zou ook op het moment van de totstandkoming van een regeerprogramma benut kunnen worden. Het is denkbaar dat verschillende actoren betrokken worden bij het maken van het regeerprogramma, mee discussiëren over prioriteiten en hun visie geven op basis van hun eigen kennis en ervaring van een bepaald beleidsterrein. Hiermee is niet gezegd dat een regeerprogramma een optelsom van interessante gedachten van verschillende betrokkenen moet zijn. Ministers en staatssecretarissen kunnen reeds bij aanvang een werkwijze introduceren die gebruik maakt van elders verworven kennis. Hier kan een gemengde praktijk van horizontale en verticale politiek goed tot zijn recht komen. Uiteindelijk is het uiteraard de regering die na weging van de inbreng van anderen, haar regeerprogramma presenteert aan het parlement.

\section{Open verhoudingen}

Met deze agenda willen wij meer rust en bedachtzaamheid brengen in de politiek.

Wat de politiek-ambtelijke verhoudingen betreft pleiten we voor een wederzijdse investering, zodat kennis en ervaring gedeeld kunnen worden met inachtneming van de onderscheiden rollen en posities. Net zo goed als de ambtenaar altijd voor zijn minister gaat staan, kunnen zich situaties voordoen waarbij de minister een mediërende rol vervult tussen ambtenaren en parlement en ervoor zorg draagt dat 'zijn' ambtenaren de ruimte krijgen om zelfstandig nieuwe posities in te nemen, en Kamerleden daarover te informeren zonder dat het vertrouwen in de minister op het spel komt te staan. Juist bij hardnekkige problemen is een open relatie tussen Kamer en departement gewenst, op sommige punten kan zelfs een vorm van samenwerking geboden zijn. De relaties tussen bewindspersonen en ambtelijke top kunnen - met inachtneming van het politiek primaat dat bij de minister ligt - winnen bij een inhoudelijk sterke betrokkenheid en inbreng van ambtenaren. Wanneer deze inbreng niet tot stand komt door een te grote nadruk op procedures, of niet wordt gewaardeerd omdat er, bijvoorbeeld in het regeerakkoord, nu eenmaal afspraken gemaakt zijn, bestaat het gevaar dat politieke besluiten de nodige inhoudelijke inbreng ontberen. Omgekeerd geldt dat de inhoudelijke inbreng van ambtenaren pas goed tot zijn recht komt binnen door de politiek aangebrachte normatieve kaders. In de politiek-ambtelijke verhoudingen die wij voorstaan gaat het om de complementariteit van de normatieve en de inhoudelijke inbreng van politici en ambtenaren. De meerwaarde van politiek en overheid is gelegen in de onderlinge verbinding.

Het vertrouwen van burgers in overheid en politiek is gebaat bij ambtenaren, ministers en politici die collectief investeren in de oplossing van maatschappelijke vraagstukken. Daartoe is niet alleen nodig dat ze elkaar als verschillende machten in evenwicht houden en controleren, maar ook dat ze van tijd tot tijd hun onderscheiden verantwoordelijkheden bundelen om te leren. De Nederlandse samenleving beschikt over een rijke praktijk waarin op basis van wederzijds vertrouwen geleerd kan worden met de 'ongetemde' problemen om te gaan 
waarmee overheid en politiek steeds weer worden geconfronteerd. Een overheid die op basis van democratische politiek een effectief en legitiem beleid realiseert is zonder twijfel de beste van alle mogelijke regeringen. Maar juist omdat deze vorm van bestuur niet generiek inzetbaar is maar steeds opnieuw bepaald en gespecificeerd dient te worden, is zorg voor de inhoud, de wijze van afwegen en beoordelen onontbeerlijk. De praktijk waarin wij verschillende tradities op een effectieve manier weten te verbinden, verdient het om zorgvuldig te worden onderhouden. Of zoals Voltaire (1759: 233) in Candide ou l'optimisme reeds schreef: “Tous les événements sont enchaînés dans le meilleur des mondes possibles; [...] - Cela est bien dit, [...] mais il faut cultiver notre jardin.” De overheid moet de ruimte krijgen om te leren. 


\section{LITERATUUR}

Andeweg, R.B. en J. Thomassen (2003) 'Tekenen aan de wand? Kamerleden, kiezers en commentatoren over de kwaliteit van de parlementaire democratie in Nederland', in: Jaarboek parlementaire geschiedenis, 2003: 26-35.

Ankersmit, F.R. (1996) Aesthetic politics. Political philosophy beyond fact and value, Stanford: Stanford University Press.

Batenburg, I. (2005) De Nederlandse rechter en collectieve actie; het ESH voorbij: het Comité van Deskundigen spreekt zich uit over het collectieve actierecht in Nederland, doctoraalscriptie Erasmus Universiteit.

Beetham, D. (1991) 'Models of bureaucracy', in: G. Thompson, J. Frances, R. Levacic en J. Mitchell (eds.) Markets, hierarchies $\&$ networks: The co-ordination of social life, Londen: Sage.

Bekker, P. (2005) Political cynicism: A hard feeling or an easy way to keep distance? Paper for panel 4 'Citizens and politics: political cynicism' of the Political Psychology Section at the ECPR general conference in Budapest, 8-11 September 2005.

Berg, J.Th.J. van den, en B. van den Braak (2004) 'Kamerleden als passanten in de Haagse politiek. De maatschappelijke herkomst van Tweede Kamerleden 1970-2004', in: Jaarboek parlementaire geschiedenis, 2004: 69-81.

Berlin, I. (1958) Four Essays on Liberty, Oxford: Oxford University Press.

Beus, J. de (2006) 'Te veel transparantie werkt niet, laat politici de ruimte om te besturen', in: de Volkskrant, 24 juni 2006.

Bock, G., Q. Skinner, et al., (eds.) (1990). Machiavelli and Republicanism. Cambridge: Cambridge University Press.

Bos, A. en J. Loots (2004) 'Kop van Jut. Zesentachtig jaar kritiek op de evenredige vertegenwoordiging', in: Jaarboek parlementaire geschiedenis, 2004: 24-33.

Bovend'Eert, P.P.T. en H.R.B.M. Kummeling (2004) Het Nederlandse Parlement, 1oe druk, Deventer: Kluwer.

Bovens, M. (2005) 'De verspreiding van de democratie', Beleid en maatschappij 32, 3:119-127.

Bovens, M., W. Derksen, W. Witteveen, F. Becker en P. Kalma (1995) De verplaatsing van de politiek. Een agenda voor democratische vernieuwing. Amsterdam: Wiardi Beckman Stichting.

Breedveld, W. (200o) Tegenmacht gevraagd. Voor de noodzakelijke herovering van het parlement, Amsterdam: De Balie.

Breedveld, W. en W. van Zanten (2004) 'De waakhond zaait verwarring. Hoe de media de democratie onder druk zetten', in: Jaarboek parlementaire geschiedenis, 2004: 34-43.

Broeders, D. en W. van de Donk (2004) 'Macht of onmacht van de media? Enkele kanttekeningen bij een actueel debat', in: E.R. Engelen en M. Sie Dhian Ho (red.) De staat van de democratie. Democratie voorbij de staat. WRR Verkenningen nr. 4. Amsterdam: Amsterdam University Press.

Broeders, D. en I. Verhoeven (2005) 'Kiezen uit overvloed. Sociaal-culturele ontwikkelingen in vraag en aanbod $n$ het medialandschap', in: W.B.H.J. van de Donk, D.W.J. Broeders en F.J.P.M. Hoefnagel (red.) Trends in het medialandschap. Vier verkennningen, WRR Verkenningen nr. 4. Amsterdam: Amsterdam University Press. 
Bureau Algemene Bestuursdienst (2006) Bekend maakt bemind. Tweede Kamerleden en ambtenaren in gesprek. Den Haag, Ministerie van Binnenlandse Zaken.

Chapman, J. (2002) System failure, Londen: Demos (www.demos.co.uk).

Chavannes, M. (1994) De stroperige staat: kanttekeningen bij de liefste democratie op aarde, Amsterdam/Antwerpen: Contact.

Churchman, C. (1967) 'Wicked problems', Management science, 4 (14): 141-142.

Commissie Evaluatie Vreemdelingenwet 2000 (2006) Evaluatie Vreemdelingenwet 2000. De asielprocedurede-Deel 1. WoDC Den Haag: Boom Juridische uitgevers.

Crick, B. (1962) In defense of politics, Chicago: University of Chicago Press.

Crince le Roy, R. (1967) De vierde macht, 's-Gravenhage.

Daalder, H. (1989) Ancient and Modern Pluralism in the Netherlands, Working Paper Series 22, Cambridge (MA): Center for European Studies, Harvard University.

Dekker, P. (2006) 'Andere burgers', blz. 145-146 in: P.L. Meurs, E.K. Schrijvers en G.H. de Vries (red.) Leren van de praktijk. Gebruik van lokale kennis en ervaring voor beleid, WRR verkenningen nr. 12, Amsterdam: Amsterdam University Press.

Dewey, J. (1927) The public and its problems, Athens: Swallow Press (reprint).

Dijsselbloem, J. en E. Kalsbeek (2005) Tussen regels en realiteit. Een praktijkonderzoek, Partij van de Arbeid.

Dijstelbloem, H.O., en P.L. Meurs (2004) 'Publieke verantwoording in de maatschappelijke dienstverlening, blz. 113-131 in: Engelen E.R. en M. Sie Dhian Ho (red.) De staat van de democratie. Democratie voorbij de staat. WRR verkenning 4. Amsterdam: Amsterdam University Press.

Donk, W.B.H.J. van de (1997) De arena in schema: Een verkenning van de betekenis van informatisering voor beleid en politiek inzake de verdeling van middelen onder verzorgingshuizen, Lelystad: Vermande.

Doorn, J.J.A. van (1998) ‘Een verdeeld Nederland in historisch perspectief’, in: M. Bovens, H. Pelikaan (red.) Nieuwe tegenstellingen in de Nederlandse politiek. Amsterdam: Boom.

Douglas, M. en A. Wildavski (1983) Risk and culture. An essay on the selection of technological and environmental dangers, Berkely.

Drenth von Februar, M. (2006) 'De rapporterende burger', blz.167-181 in: P.L. Meurs, E.K. Schrijvers en G.H. de Vries (red.) Leren van de praktijk. Gebruik van lokale kennis en ervaring voor beleid, WRR verkenningen nr.12, Amsterdam: Amsterdam University Press.

Frissen, P. H.A. (1996) De virtuele staat. Politiek, bestuur en technologie: een postmodern verhaal, Schoonhoven: Academic Service.

Gallie, W.B. (1955-56) 'Essentially contested concepts', Proceedings of the Aristotelian Society 56: 167-198.

Gelderen, M. van, en Q. Skinner (eds.) (2002) Republicanism: a shared European heritage, Vol. II. Cambridge: Cambridge University Press.

Gerritsen, H, T. de Leeuw en M. Verheij (2001) Project Nieuwe Vreemdelingenwet 2000. Historie van een uniek wetgevingsproject. Den Haag, Ministerie van Justitie.

Gunsteren, H.R. van, en E. van Ruyven (red.) (1995) Bestuur in De Ongekende Samenleving, Den Haag: Sdu Uitgevers.

Gunsteren, H. van (1994) Culturen van besturen, Amsterdam: Boom.

Gunsteren, H. van (2006) 'Vertrouwen in democratie', blz. 215-237 in: P.L. Meurs, 
E.K. Schrijvers en G.H. de Vries (red.) Leren van de praktijk. Gebruik van lokale kennis en ervaring voor beleid, WRR verkenningen nr.12, Amsterdam: Amsterdam University Press.

Gusfield, J. (1981) Drinking driving and the symbolic order. The culture of public problems, Chicago: The University Press.

Haan, I. de (1993) Tussen zelfbestuur en staatsbeheer. Het politieke debat over burgerschap en rechtsstaat in de twintigste eeuw, Amsterdam: Amsterdam University Press.

Habermas, J. (1985) Die neue Unübersichtlichkeit, Frankfurt am Main: Suhrkamp.

Hall, P.A. (1993) 'Policy paradigms, social learning, and the state', Comparative politics, april, p. 275-296.

Hart, P. 't (2001) Verbroken verbindingen. Over politisering van het verleden en de dreiging van een inquisitiedemocratie, Amsterdam: De Balie.

Hart, P. 't, A. Wille et al. (2002) Politiek-ambtelijke verhoudingen in beweging, Amsterdam: Boom.

Hart, P. 't en A. Wille (2006) 'Ministers and Top Officials in the Dutch Core Executive: Living Together, Growing Apart?’, Public Administration, 84: 121-146.

Hay, C. (2004) 'The normalizing role of rationalist assumptions in the institutional embedding of neoliberalism', Economy and Society, 33, 4: 500-527.

Healy, P. et al., Science Technology and Governance in Europe: Challenges of Public Engagement, Brussel, EU, STAGE (HPSE-CT 2001-50003) Final Report February 2005.

Heclo, H. (1974) Modern social policies in Britain and Sweden: from relief to income maintenance, New Haven: Yale University Press.

Hemerijck, A. (2003) 'Vier kernvragen van beleid, Beleid en Maatschappij, 30: p.3-19.

Hertogh, M. (2006) 'Bier werkt beter dan koffie. Over de bestuurlijke beleving van het gelijkheidsbeginsel’, blz. 19-39 in: P.L. Meurs en E.K. Schrijvers en G.H. de Vries (red.) Leren van de praktijk. Gebruik van lokale kennis en ervaring voor beleid, WRR verkenningen nr. 12, Amsterdam: Amsterdam University Press.

Hirschman, A.O. (1972) Exit, Voice and Loyalty: Responses to declines in firms, organizations and states, Cambridge (Mass.): Harvard University Press.

Hisschemöller, M. (1993) De democratie van problemen. De relatie tussen de inhoud van beleidsproblemen en methoden van politieke besluitvorming, Amsterdam: vu Uitgeverij.

Hood, C. en B.G. Peters (2004) 'The middle-aging of New Public Management: into the age of paradox?', Journal of public administration research and theory, 14, nr. 3 , p. $267-282$.

Hoppe, R. (1989) Het beleidsprobleem geproblematiseerd:over beleid ontwerpen en probleemvorming, Muiderberg: Coutinho.

Israel, J.I. (1995) The Dutch Republic: its Rise, Greatness, and Fall 1477-1806, Oxford: Oxford University Press.

Jekel, H. (2005) De ontbrekende dialoog. Over nieuwe ambtenaren, nationale politici en de noodzaak tot dialoog, Den Haag: Sdu Uitgevers.

Jeliazkova, M.I. en R. Hoppe (1996) 'Beroepsbeelden van de beleidsambtenaar: Een onderzoek onder beleidsfunctionarissen bij een departement', Beleidswetenschap 10(2): 124-153.

Kelly, T. (2004) 'Unlocking the iron cage. Public administration in the deliberative 
democratic theory of Jürgen Habermas', Administration \& Society, vol. 36, nr. 1, p. 38-61.

Kennedy, J.C. (2003) Crisis en vernieuwing. De valkuilen van de Nederlandse politieke retoriek, Eerste ROB-Lezing, 11 september 2003: Den Haag.

Kennedy, J.C. (2004) 'De democratie als bestuurskundig probleem. Vernieuwingsstreven in de Nederlandse politiek sinds 1918', Jaarboek parlementaire geschiedenis. Nijmegen: Centrum voor parlementaire geschiedenis, p. 12-23.

Kickert, W.J.M. (2005) 'Overheidshervormingen in het verleden. Reflecties door betrokkenen', Bestuurswetenschappen 59, nr. 4: 326-350.

Kossmann, E.H. (2005) Geschiedenis is als een olifant- Een keuze uit het werk van E.H. Kossmann. Amsterdam, Bert Bakker.

Kuhn, T.S. (1970). The Structure of Scientific Revolutions. Chicago, Chicago University Press.

Latour, B. en P. Weibel (eds.) (2005). Making Things Public. Atmospheres of Democracy. Cambridge (Mass.): MIT Press.

Lendering, J. (2005) Polderdenken. De wortels van de Nederlandse overlegcultuur. Amsterdam: Athaeneum-Polak\&Van Gennep.

Lindblom, Ch.E. (1959) 'The science of "muddling through", Public Administration Review, 19, p. 79-99.

Lindblom, Ch.E. (1965) The intelligence of democracy. New York: Free Press.

Lodge, M. en C. Hood (2005) 'Symposium introduction: competency and higher civil servants', Public administration, vol. 83, nr. 4, p. 779-787.

Madison, J, A. Hamilton en John Jay (1987) The Federalist Papers, (I. Kramnick, ed.), Londen: Penguin Books.

March, J.G. and J.P. Olsen (1989) Rediscovering institutions: the organizational basis of Politics. New York: The Free Press.

March, J.G. en J.P. Olsen (1995) Democratic Governance, New York: The Free Press.

Marres, N. (2005) No issue, no public-democratic deficits after the displacement of politics. proefschrift Universiteit van Amsterdam.

Meer, F.M. van der, en T.A.J. Toonen (2005) 'Competency management and civil service professionalism in Dutch central government', Public administration, vol. 83, nr. 4, p. 839-852.

Mertens, (1996) Vriendelijk converseren en krachtig optreden: over vakmanschap in de beleidsadvisering, Oratie Erasmus Universiteit Rotterdam

Ministerie van Binnenlandse Zaken (1996) Plan van aanpak Algemene Bestuursdienst $(A B D)$, Den Haag.

Ministerie van Binnenlandse Zaken (2004) Voortgangsrapportage 2004 Programma Andere Overheid, Den Haag.

Muller, E.R. en N.J.P. Coenen (2002) Parlementair onderzoek in Nederland, Den Haag: Sdu Uitgevers.

Sas, N. van (2004) De metamorfose van Nederland. Van oude orde naar moderniteit 1750-1900, Amsterdam: Amsterdam University Press.

Niessen C.R. (2003) Ambtenaar in de overheidsorganisatie, Studiepockets staats- en bestuursrecht nr. 42, Deventer: Kluwer.

Nieuwenkamp, R. (2001) De prijs van het politieke primaat. Rotterdam: Eburon.

Noordegraaf, M. (2006) 'Tussen politiek en praktijk. Leren van straten, spreekkamers 
en schoolklassen', blz. 185-210 in: P.L. Meurs, E.K. Schrijvers en G.H. de Vries (red.) Leren van de praktijk. Gebruik van lokale kennis en ervaring voor beleid, WRR verkenningen nr. 12, Amsterdam: Amsterdam University Press.

Noordegraaf, M. (2004) Management in het publieke domein. Issues, instituties en instrumenten, Bussum: Coutinho.

Office of Technology Assessment, United States Congress (1995) The OTA Legacy, Washington (CD-ROM).

Oosterveer, P. (2005) Global Food Governance, Wageningen: Wageningen University.

Peters, K. (2006) 'Impuls voor de lokale democratie? De casus van de WMO', blz. 41-66 in: P.L. Meurs, E.K. Schrijvers en G.H. de Vries (red.) Leren van de praktijk. Gebruik van lokale kennis en ervaring voor beleid, wRR verkenningen nr. 12, Amsterdam: Amsterdam University Press.

Pierre, J. en B. Guy Peters, Governance, Politics and the State, St. Martin's Press, New York, 2000.

Pierson, P. (1994) Dismantling the welfare state? Reagan, Thatcher and the politics of retrenchment, Cambridge: Cambridge University Press.

Pierson, P. (ed.) (2001) The new politics of the welfare state, Oxford: Oxford University Press.

Plato, 'Politeia' in: Plato (1973) The Collected Dialogues of Plato. Princeton: Princeton University Press.

Polanyi, M. (1962). 'The Republic of Science - Its Political and Economic Theory', Minerva 1: $54-74$.

Raad van State (2006) Jaarverslag 2005, Den Haag: Raad van State.

Ringeling, A.B. (2004) 'Wie vertegenwoordigt wat? en hoe?', blz. 15-32 in: Raad voor het Openbaar Bestuur, Democratische vergezichten. Essays over de representatieve democratie in Nederland, Den Haag.

Rittel, H., en M. Webber (1973) 'Dilemmas in a General Theory of Planning', Policy Sciences, Vol. 4, Amsterdam: Elsevier Scientific Publishing Company, Inc.: 155-169.

Raad voor het Openbaar Bestuur, (2005) Niet teveel gevraagd! Een analyse van Kamervragen, Den Haag.

Sabel, C.F. (2004) 'Beyond principal-agent governance: Experimentalist organisations, learning and accountability’, in: E.R. Engelen en M. Sie Dhian Ho (red.) De staat van de democratie. Democratie voorbij de staat, wRR verkenningen nr. 4, Amsterdam: Amsterdam University Press.

Scharpf, F.W. (1997) Games real actors play. Actor-centered institutionaism in policy research, Oxford: Westview Press.

Scharpf, F.W. (1988) 'The joint decision trap: lessons from German federalism and European Integration', Public administration, 66: 239-278.

Schmidt, V.A. (2003) 'How, where, and when does discourse matter in small states' welfare state adjustment?’, New Political Economy, vol. 8, no. 1.

Scott, J.C. (1998) Seeing like a State: How certain schemes to improve the human condition have failed, New Haven: Yale University Press.

Skinner, Q. (1990) 'The republican ideal of political liberty. Machiavelli and Republicanism'. G. Bock, Q. Skinner and M. Viroli. Cambridge: Cambridge University Press. 
Skinner, Q. (2002) Visions of Politics, Volume II: Renaissance Virtues. Cambridge, Cambridge University Press.

Snellen, I. (1987) Boeiend en geboeid. Ambivalenties en ambities in de bestuurskunde, Oratie Katholieke Universiteit Brabant, Alphen aan den Rijn: Kluwer.

Sociaal en Cultureel Planbureau (2006) De sociale staat van Nederland. Den Haag: SCP.

Stokkom, B. van, en J. Terpstra (2006) 'Probleemgericht werken in lokale veiligheidsnetwerken', blz. 91-115 in: P.L. Meurs, E.K. Schrijvers en G.H. de Vries (red.) Leren van de praktijk. Gebruikvan lokale kennis en ervaring voor beleid, WRR verkenningen nr. 12, Amsterdam: Amsterdam University Press.

Stone, D.A. (2002) Policy paradox : the art of political decision making, New York: Norton.

Strijers, A. (2003) Belangenafweging in de rechtsstaat: drie casussen, WRR-werkdocumenten 132, Den Haag.

Taylor, C. (1997) Philosophical Arguments, Harvard: Harvard University Press.

Thijn, E. van, en T. Cardoso Ribeiro (2004) De informatieparadox. Een blinde vlek in het openbaar bestuur, Den Haag: Lemma.

Toonen, Th.A.J. en F. Hendriks (2005) 'The embarrassment of success: institutional underpinning of polder politics', blz. 265-289 in: F. Hendriks en Theo A.J. Toonen (eds.) Polder politics. The reinvention of consensus democracy in the Netherlands. Aldershot: Ashgate.

Toren, P.J. van den (1996) Achter gesloten deuren? CAO-overleg in de jaren negentig, Amsterdam: Welboom.

Tweede Kamer (2003) 29 941, nr.6, p. 8.

Twist, M. van (1995) Verbale vernieuwing, aantekeningen over de kunst van bestuurskunde. Den Haag, VUGA.

Veld, R. in 't (1995) Spelen met vuur. Den Haag, vugA.

Velde, H. te (2002) Stijlen van leiderschap. Persoon en politiek van Thorbecke tot Den Uyl, Amsterdam: Wereldbibliotheek.

Verhoeven, I. (2006) 'Alledaags politiek burgerschap en de overheid', blz. 119-143 in: P.L. Meurs, E.K. Schrijvers en G.H. de Vries (red.) Leren van de praktijk. Gebruik van lokale kennis en ervaring voor beleid, WRR verkenningen nr. 12, Amsterdam: Amsterdam University Press.

Viroli, M. (1992) From Politics to Reason of State. The Acquisition $\mathbb{8}$ Transformation of the Language of Politics 1250-16oo, Cambridge: Cambridge University Press.

Visscher, G. (1999) 'Geen onderzoek met "eene tegen het gouvernement vijandige strekking”? De parlementaire enquête in verleden en heden', in: Jaarboek parlementaire geschiedenis, 1999: 12-26.

Visscher, G. (2000) 'Staatkundige vernieuwing in de twintigste eeuw: vechten tegen de bierkaai?’, in: Jaarboek parlementaire geschiedenis, 2000: 12-27.

Visser, J. en A. Hemerijck (1998) Een Nederlands Mirakel. Beleidsleren in de verzorgingsstaat, Amsterdam: Amsterdam University Press.

Voltaire (1979) 'Candide ou l'optimisme', in: idem Romans et contes, Paris: Gallimard (oorspronkelijk 1759).

Vries, G. de (2006) 'Prenatale screening: beperking van legitieme politiek en redelijk bestuur', blz. 67-89 in: P.L. Meurs, E.K. Schrijvers en G.H. de Vries (red.) Leren van de praktijk. Gebruik van lokale kennis en ervaring voor beleid, WRR verkenningen nr.12, Amsterdam: Amsterdam University Press, p. 67-89. 
Wagenaar, H. (2005) Stadswijken, Complexiteit en Burgerbestuur, Den Haag: XPIN.

Wallage, J. (2005) Lang leve de ambtenaar. Over de rol van beleidsambtenaren, Amsterdam: Bert Bakker.

Weber, M. (1968) 'Wissenschaft als Beruf', in: M. Weber, Gesammelte Aufsätze zur Wissenschaftslehre. M. Weber. Tübingen, J.C.B. Mohr (Paul Siebeck): 582-613.

Weber, M. (1972) Wirtschaft und Gesellschaft. Tübingen, J.C.B. Mohr (Paul Siebeck).

Weber, M. (1988) Politik als Beruf. Gesammelte Politische Schriften. M. Weber. Tübingen, J.C.B. Mohr (Paul Siebeck): 505-560.

Wetenschappelijke Raad voor het Regeringsbeleid (2002) De toekomst van de nationale rechtstaat, Rapporten aan de regering nr. 63, Den Haag: Sdu Uitgevers.

Wetenschappelijke Raad voor het Regeringsbeleid (2003) Waarden, normen en de last van het gedrag, Rapporten aan de regering nr. 68, Amsterdam: Amsterdam University Press.

Wetenschappelijke Raad voor het Regeringsbeleid (2004) Bewijzen van goede dienstverlening, Rapporten aan de regering nr. 70, Amsterdam: Amsterdam University Press.

Wetenschappelijke Raad voor het Regeringsbeleid (2005) Vertrouwen in de buurt, Rapporten aan de regering nr. 72, Amsterdam: Amsterdam University Press.

Wille, A. (2005) 'Kamervragen en de dagelijkse drang van politieke controle', Bestuurswetenschappen 2005 , nr. 5 .

Witteveen, W.J. en B.M.J. Klink et al. (2002) De sociale rechtstaat voorbij, WRR Voorstudies en Achtergronden, nr. V116, Den Haag: Sdu Uitgevers.

Zuurmond, A. (1994) De Infocratie: een theoretische en empirische heroriëntatie op Weber's ideaaltype in het informatietijdperk, Den Haag: Phaedrus. 


\section{RAPPORTEN AAN DE REGERING}

\section{Eerste raadsperiode (1972-1977)}

1 Europese Unie

2 Structuur van de Nederlandse economie

3 Energiebeleid

Gebundeld in één publicatie (1974)

4 Milieubeleid (1974)

5 Bevolkingsgroei (1974)

6 De organisatie van het openbaar bestuur (1975)

7 Buitenlandse invloeden op Nederland: Internationale migratie (1976)

8 Buitenlandse invloeden op Nederland: Beschikbaarheid van wetenschappelijke en technische kennis (1976)

9 Commentaar op de Discussienota Sectorraden (1976)

10 Commentaar op de nota Contouren van een toekomstig onderwijsbestel (1976)

11 Overzicht externe adviesorganen van de centrale overheid (1976)

12 Externe adviesorganen van de centrale overheid (1976)

13 Maken wij er werk van? Verkenningen omtrent de verhouding tussen actieven en niet-actieven (1977)

14 Interne adviesorganen van de centrale overheid (1977)

15 De komende vijfentwintig jaar - Een toekomstverkenning voor Nederland (1977)

16 Over sociale ongelijkheid - Een beleidsgerichte probleemverkenning (1977)

Tweede raadsperiode (1978-1982)

Etnische minderheden (1979)

A. Rapport aan de Regering

B. Naar een algemeen etnisch minderhedenbeleid?

Plaats en toekomst van de Nederlandse industrie (1980)

Beleidsgerichte toekomstverkenning

Deel 1: Een poging tot uitlokking (1980)

Democratie en geweld. Probleemanalyse naar aanleiding van de gebeurtenissen in Amsterdam op 30 april 1980

Vernieuwingen in het arbeidsbestel (1981)

Herwaardering van welzijnsbeleid (1982)

Onder invloed van Duitsland. Een onderzoek naar gevoeligheid en kwetsbaarheid in de betrekkingen tussen Nederland en de Bondsrepubliek (1982)

Samenhangend mediabeleid (1982)

\section{Derde raadsperiode (1983-1987)}

Beleidsgerichte toekomstverkenning

Deel 2: Een verruiming van perspectief (1983)

Waarborgen voor zekerheid. Een nieuw stelsel van sociale zekerheid in hoofdlijnen (1985)

Basisvorming in het onderwijs (1986)

De onvoltooide Europese integratie (1986)

Ruimte voor groei. Kansen en bedreigingen voor de Nederlandse economie in de komende tien jaar (1987)

Op maat van het midden- en kleinbedrijf (1987)

Deel 1: Rapport aan de Regering

Deel 2: Pre-adviezen 
De financiering van de Europese Gemeenschap. Een interimrapport (1987)

Activerend arbeidsmarktbeleid (1987)

Overheid en toekomstonderzoek. Een inventarisatie (1988)

\section{Vierde raadsperiode (1988-1992)}

Rechtshandhaving (1988)

Allochtonenbeleid (1989)

Van de stad en de rand (1990)

Een werkend perspectief. Arbeidsparticipatie in de jaren '90 (1990)

Technologie en overheid (1990)

De onderwijsverzorging in de toekomst (1991)

Milieubeleid. Strategie, instrumenten en handhaafbaarheid (1992)

Grond voor keuzen. Vier perspectieven voor de landelijke gebieden in de Europese Gemeenschap (1992)

Ouderen voor ouderen. Demografische ontwikkelingen en beleid (1993)

\section{Vijfde raadsperiode (1993-1997)}

Duurzame risico's. Een blijvend gegeven (1994)

Belang en beleid. Naar een verantwoorde uitvoering van de werknemersverzekeringen (1994)

Besluiten over grote projecten (1994)

Hoger onderwijs in fasen (1995)

Stabiliteit en veiligheid in Europa. Het veranderende krachtenveld voor het buitenlands beleid (1995)

Orde in het binnenlands bestuur (1995)

Tweedeling in perspectief (1996)

Van verdelen naar verdienen. Afwegingen voor de sociale zekerheid in de 21e eeuw (1997)

Volksgezondheidszorg (1997)

Ruimtelijke-ontwikkelingspolitiek (1998)

Staat zonder land. Een verkenning van bestuurlijke gevolgen van informatie- en communicatietechnologie (1998)

\section{Zesde raadsperiode (1998-2002)}

Het borgen van publiek belang (2000)

Doorgroei van arbeidsparticipatie (2000)

Ontwikkelingsbeleid en goed bestuur (2001)

Naar een Europabrede Unie (2001)

Nederland als immigratiesamenleving (2001)

Van oude en nieuwe kennis. De gevolgen van ICT voor het kennisbeleid (2002)

Duurzame ontwikkeling. Bestuurlijke voorwaarden voor een mobiliserend beleid (2002)

De toekomst van de nationale rechtsstaat (2002)

Beslissen over biotechnologie (2003)

Slagvaardigheid in de Europabrede Unie (2003)

Nederland handelsland. Het perspectief van de transactiekosten (2003)

Naar nieuwe wegen in het milieubeleid (2003) 


\section{Zevende raadsperiode (2003-2007)}

Waarden, normen en de last van het gedrag (2003)

De Europese Unie, Turkije en de islam (2004)

71 Focus op functies. Uitdagingen voor een toekomstbestendig mediabeleid (2005)

72 Vertrouwen in de buurt (2005)

73 Dynamiek in islamitisch activisme. Aanknopingspunten voor democratisering en mensenrechten (2006)

Rapporten aan de Regering nrs $1 \mathrm{t} / \mathrm{m} 67$ en publicaties in de reeks Voorstudies en achtergronden zijn niet meer leverbaar. Alle studies van de WRR zijn beschikbaar via de website www.wrr.nl.

Rapporten aan de Regering nrs $68 \mathrm{t} / \mathrm{m} 74$ zijn verkrijgbaar in de boekhandel of via Amsterdam University Press, Prinsengracht 747-751, 1017 JX Amsterdam (www.aup.nl). 


\section{VERKENNINGEN}

\section{Zevende raadsperiode (2003-2007)}

1 Jacques Pelkmans, Monika Sie Dhian Ho en Bas Limonard (red.) (2003) Nederland en de Europese grondwet

2 P.T. de Beer en C.J.M. Schuyt (red.) (2004) Bijdragen aan waarden en normen

3 G. van den Brink (2004) Schets van een beschavingsoffensief. Over normen, normaliteit en normalisatie in Nederland

4 E.R. Engelen en M. Sie Dhian Ho (red.) (2004) De staat van de democratie. Democratie voorbij de staat

5 P.A. van der Duin, C.A. Hazeu, P. Rademaker en I.J. Schoonenboom (red.) (2004) Vijfentwintig jaar later. De Toekomstverkenning van de WRR uit 1977 als leerproces

6 H. Dijstelbloem, P.L. Meurs en E.K. Schrijvers (red.) (2004) Maatschappelijke dienstverlening. Een onderzoek naar vijf sectoren

7 W.B.H.J. van de Donk, D.W.J. Broeders en F.J.P. Hoefnagel (red.) (2005) Trends in het medialandschap. Vier verkenningen

8 G. Engbersen, E. Snel en A. Weltevrede (2005) Sociale herovering in Amsterdam en Rotterdam. Eén verhaal over twee wijken

9 D.J. Wolfson (2005) Transactie als bestuurlijke vernieuwing. Op zoek naar samenhang in beleid en uitvoering

10 Nasr Abu Zayd (2006) Reformation of Islamic Thought. A Critical Historical Analysis

11 J.M. Otto (2006) Sharia en nationaal recht. Rechtssystemen in moslimlanden tusssen traditie, politiek en rechtsstaat

12 P.L. Meurs, E.K. Schrijvers en G.H. de Vries (2006) Leren van de praktijk. Gebruik van lokale kennis en ervaring voor beleid

Alle Verkenningen zijn verkrijgbaar in de boekhandel of via Amsterdam University Press, Prinsengracht 747-751,

1017 JX Amsterdam (www.aup.nl). 


\section{WEBPUBLICATIES}

\section{Zevende raadsperiode (2003-2007)}

WP 1 Opvoeding, onderwijs en jeugdbeleid in het algemeen belang

WP 2 Ruimte voor goed bestuur: tussen prestatie, proces en principe

WP 3 Lessen uit corporate governance en maatschappelijk verantwoord ondernemen

WP 4 Regulering van het bestuur van maatschappelijke dienstverlening: eenheid in verscheidenheid

WP 5 Een schets van het Europese mediabeleid

WP 6 De regulering van media in internationaal perspectief

WP 7 Beleid inzake media, cultuur en kwaliteit: enkele overwegingen

WP 8 Geschiedenis van het Nederlands inhoudelijk mediabeleid

WP 9 Buurtinitiatieven en buurtbeleid in Nederland anno 2004: analyse van een veldonderzoek van 28 casussen

WP 10 Geestelijke gezondheid van adolescenten: een voorstudie

WP 11 De transitie naar volwassenheid en de rol van het overheidsbeleid: een vergelijking van insitutionele arrangementen in Nederland, Zweden, Groot-Brittanië en Spanje

WP 12 Klassieke sharia en vernieuwing

WP 13 Sharia en nationaal recht in twaalf moslimlanden 


\section{Lerende overheid}

Met het rapport Lerende overheid wil de raad het leervermogen van overheid en politiek versterken. Er wordt recentelijk veel gesproken over het verbeteren van het functioneren van het politieke bestel. Voorbeelden daarvan zijn een herstel van het primaat van de politiek, meer leiderschap, helder onderscheiden verantwoordelijkheden en het vooropstellen van processen en procedures binnen de overheid.

Deze 'verticale' visie op het functioneren van het politieke bestel is volgens de raad niet altijd productief. Veel problemen waarvoor de overheid komt te staan, vragen ruimte en tijd voor analyse, afweging en oordeelsvorming. Ook is vaak de inzet nodig van actoren buiten de overheid zelf: van deskundigen, burgers en maatschappelijke organisaties. In dit rapport - een vervolg op Bewijzen van goede dienstverlening bepleit de raad daarom tevens gebruik te maken van de 'horizontale' traditie van politiek. Daarin staat niet het nemen van legitieme besluiten centraal, maar het wikken en wegen en formuleren van redelijke oplossingen. Een 'gemengde' horizontale én verticale praktijk is bij uitstek geschikt om te leren hoe problemen geformuleerd en opgelost kunnen worden.

Een probleemgerichte benadering van politiek vraagt om een perspectief op de overheid waarin leervermogen centraal staat. Beslissen en doorzetten zijn belangrijk, evenals goede processen en procedures. Maar zonder het versterken en vergroten van de kennis en het oordeelsvermogen van ambtenaren en politici worden belangrijke publieke problemen ontdaan van hun inhoudelijke en normatieve lading en raakt de staat uitgehold.

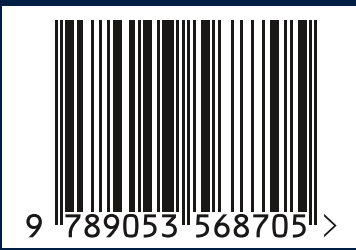

IS BN-13978-90-5356-870-5

IS B N-10 90-5356-870-0 